\title{
Proposal of a system for the integrated and comparative assessment of protected areas
}

\author{
David Rodríguez-Rodríguez, Javier Martínez-Vega
}

Keywords: Protected area - Integrated assessment - Comparative assessment - Effectiveness index - SIAPA.

Abstract: Protected areas' overall goal is to achieve the long-term conservation of natural and associated cultural goods and services. However, effective long-term conservation of natural and associated cultural resources cannot always be guaranteed by a protection regime or even by effective management, as it is usually assumed. The ultimate goal of assessing protected areas is therefore concerned less with management effectiveness than with their overall long-term effectiveness. This paper describes the methodology underpinning the System for the Integrated Assessment of Protected Areas (SIAPA). The aim of SIAPA is to make the concept of 'effectiveness' operational when applied to protected areas. It is an innovative, horizontal site-level assessment system for evaluating integrally and comparably the effectiveness of terrestrial protected areas, as the assessment is based on the same parameters. Indicators are the basic assessment units. They were weighted by an expert panel and integrated into six categories (indexes) defining the effectiveness of protected areas: state of conservation, planning, management, social and economic context, social perception and valuation, and threats to conservation. These indexes were subsequently integrated into a single super-index: an effectiveness index for the protected area. Two alternative models of the SIAPA were developed: the complete model, containing 43 indicators, in order to maximize the amount of information on each protected area; and the simplified model, containing 28 indicators, in order to maximize the cost-effectiveness of the assessment.

\section{Introduction}

\subsection{The effectiveness of protected areas}

Protected areas (PAs) are 'clearly defined geographical areas, recognized, devoted and managed, through legal means or other effective means, to attain the long-term conservation of nature and its associated ecosystem services and cultural values' (Dudley, 2008). PAs are the main global conservation strategy to mitigate current biodiversity crisis (Jenkins and Joppa, 2009; Pullin, 2002). However, we might be assuming PAs are conserving effectively their natural and cultural resources merely because they have been given protection status (Pomeroy et al., 2005; Pullin, 2002).

Recent global studies have demonstrated that, despite continuous growth in the number of and area covered by protected areas (Jenkins and Joppa, 2009; McDonald and Boucher, 2011), biodiversity and other ecosystem goods and services continue to be lost (Butchart et al., 2010). It is accepted that the sole designation of an area as 'protected' does not imply that it is effectively conserved and that, in order for it to be so, it should also have effective management (Ervin, 2003; Hockings et al., 2006; Nolte et al., 2010; Pomeroy et al., 2005). But is effective management enough to achieve long-term conservation of ecosystems goods and services?

\subsection{The need to assess protected area effectiveness on common parameters}

The evaluation of PAs has become a priority for adaptive management and early-warning strategies in a context of global change (Alcaraz-Segura et al., 2009; Hockings et al., 2006; Pomeroy et al., 2005). One of the targets of the Programme of Work on Protected Areas of the Convention on Biological Diversity (CBD) was to adopt and implement, 'by 2010, frameworks for monitoring, evaluating and reporting protected area management effectiveness at sites, national and regional systems. . .' (Nolte et al., 2010). Currently, this target has been expanded to cover $60 \%$ of the total area covered by protected areas by 2015 (CBD, 2010).

Such evaluations often take the form of PA assessments, PA management effectiveness (PAME) evaluations or PA effectiveness evaluations, terms that are frequently used interchangeably (Ervin, 2003). As precise, sound definitions are fundamental to science (Spangenberg, 2011), some order and clarification is needed in the rapidly developing field of PA assessment.

Moreover to our knowledge, a common, non opinionbased framework for assessing and reporting the effectiveness of individual PAs from similar contexts between the level of PA network assessments and specific goal-oriented site assessments remains undeveloped, 
despite its interest for PA managers, PA network managers, policy-makers and scientists.

\subsection{Management effectiveness evaluation as a part of $P A$ effectiveness evaluation}

According to the most updated definition of PAs by the IUCN (Dudley, 2008), a PA can be deemed "effective" only if it is capable of conserving the entire set of nature and associated ecosystem services and cultural values it harbors in the long-term, something that effective management cannot always guarantee (Jameson et al., 2002).

Hockings et al. (2000) provided a valid, useful framework for assessing individual PAs comprehensibly (Ervin, 2003; Stoll- Kleemann, 2010). The framework has, however, linguistic and conceptual limitations.

First, the term 'management effectiveness' can be confusing for both managers and evaluators, as PAME may include context variables (Hockings et al., 2006) that are outside the means, aims or competence of PA managers, such as those related to economy, society, regional or global threats. The intensity of and trends in such variables may make on-site management efforts largely inefficient (Alcaraz-Segura et al., 2009; Araújo et al., 2011; Gaston et al., 2006; Radeloff et al., 2010), especially in the marine environment (Jameson et al., 2002).

Current PAME terminology may also be unfair to PA managers, who might be held responsible for outside circumstances that they cannot control or even influence. Furthermore, a precise PAME would exclude many protected areas, as PAME should be target-driven (Hockings et al., 2006), many PAs lack specific management goals or targets (Bertzky and StollKleemann, 2009; Paleczny and Russell, 2005; Pomeroy et al., 2005), and, when such goals exist, they are often ambiguous or even contradictory (Naughton-Treves et al., 2005).

Thus, it is doubtful that the result of an assessment within this wide framework in fact relates to 'management effectiveness'. Even if management represents an essential part of PA assessments, the core phenomenon assessed should be related less to management than to the effective long-term conservation of the goods and services provided by these areas (Bertzky and Stoll-Kleemann, 2009; Ervin, 2003; Paleczny and Russell, 2005; Parrish et al., 2003). Parrish et al. (2003) used the term 'ecological integrity' of PAs, and Gaston et al. (2006) used 'ecological effectiveness' although both approaches are strictly ecology-driven. Therefore, for the sake of scientific precision and clarity, it would be more appropriate to call an integrated approach to PA assessment that includes broad context variables a 'PA effectiveness evaluation' (PAEE), of which PAME is a crucial part. This proposed new nomenclature covers all types of PAs, regardless of the existence of effective management or management objectives.

We propose that the term 'PAME' be used only for assessment of those aspects of PAs that are directly linked to management (and, ideally, where clear management objectives have been set up), whereas 'PAEE' should be used for a wider framework, including PAME but also relevant context variables not directly linked to management and not requiring the existence of specific management objectives.

\subsection{The system for the integrated assessment of protected areas (SIAPA)}

In response to the need for sound environmental decision support systems (CBD, 2010; Ostendorf, 2011), the SIAPA has the following objectives: (1) to clarify the concept of 'PA effectiveness'; (2) to make the concept operational, by identifying a set of management and policy-relevant indicators and indexes for use in an integrated manner; (3) to present a common, rigorous, simple, cost-effective, adaptable assessment framework for use at site level in a wide range of terrestrial PAs and for comparing different PAs from similar contexts, regardless of their size, protection category or the type of ecosystems they include; (4) to identify the strengths and limitations of PAs for attaining long-term conservation of their natural and associated cultural resources; (5) to assist managers and decision-makers in making informed management decisions; (6) to encourage effective cooperation between administrations and among scientists, managers and policy-makers; and (7) to promote transparency and accountability in the public and private sectors.

\section{Methods}

\subsection{Identification of indicators and categories}

A first set of 105 indicators that might be meaningful for the effectiveness of PAs was identified after an initial literature review, as done for relevant variable identification in other studies (Chuvieco et al., 2010). The review covered published hard copies and online scientific and technical books and papers (non-exhaustive list provided) on conservation science (Pullin, 2002), PAs (Chape et al., 2008; Dudley, 2008), PA assessment (Hockings et al., 2000, 2006; Mallarach et al., 2008; Pomeroy et al., 2005), biodiversity assessment (Spellerberg, 1992), environmental indicators (EEA, 1999; Ramírez, 2002) and sustainable development (Jiménez et al., 2005; OECD, 1993), in both English and Spanish. Six broad categories related to the effectiveness of PAs were also identified after this review: 'State of conservation', 'Planning', 'Management', 'Social and economic context', 'Social perception and valuation', and 'Threats to conservation'.

\subsection{Selection of final set of indicators}

The set of potential indicators was shortlisted to a manageable final selection by removing redundancies and by consultation with experts, as in other studies (Chuvieco et al., 2010; Fraser et al., 2006; Martínez-Vega et al., 2009). 
The expert panel comprised representatives of government bodies: the Division of PAs of the Regional Ministry of Environment of the Autonomous Region of Madrid (CMAOT, responsible for managing PAs in the region) and the National Ministry of Environment and Rural and Marine Affairs (MARM); research agencies: the Centre for Environmental Research of the Region of Madrid (CIAM), the Regional Foundation for Environmental Research and Development (FIDA), the Spanish Observatory for Sustainability (OSE), the Faculty of Biology of the Complutense University of Madrid (UCM), the national section of the Europarc Federation (Europarc-Spain) and the Catalan Institute of Natural History (ICHN); and environmental nongovernmental organizations: Greenpeace-Spain, SEO-Birdlife, WWFADENA, and Ecologistas en Acción (EEA).

Each person from the expert panel was contacted by phone, told the aim of the study and asked to score each of the proposed indicators according to their importance for assessing the long-term conservation of a PA, as 1 (minimum importance), 2 (moderate importance) or 3 (maximum importance). An excel sheet containing the 105 pre-selected indicators was subsequently e-mailed to each expert. Replies in the required format (numerical) were provided only by the MARM, the OSE and the CMAOT. A final set of 40 indicators was selected according to the scores given by these experts and by the authors. Written replies were provided by the CIAM, the UCM, the ICHN, Greenpeace-Spain and SEO-Birdlife, which were used to clarify a final selection from the numerical replies. They suggested the inclusion of a low-scored indicator, 'evolution of temperature', which was subsequently renamed and developed as 'climate change'. These replies also suggested the inclusion of two new indicators: 'landscape impact' and 'evolution of the designated area'. As a result, a final selection of 43 indicators was made.

\subsection{Selection of spatial and temporal scales}

Regarding space, the whole area of the PAs as defined by law (based on administrative boundaries) was selected as the reference spatial scale for the assessment. For large, zoned PAs (parks), a more detailed assessment scale (management zone) was analyzed when valuating and interpreting the indicator. The values obtained for each management zone were subsequently integrated to obtain a single value for the whole PA by giving a greater weight to the variables inside core zones than in buffer or transition zones, respectively. Thus, whereas a unique assessment scale was generally used for small protected areas (the whole PA), two complementary scales were analyzed for large protected areas when possible: management zones and the whole PA.

Regarding time, for a first assessment, we planned to assess each indicator since the legal designation of each PA. When this was not possible, we used the first available data. As a result, the period of the available rough data for some indicators differed. The period of available information for each indicator was specified. However, the same assessment date was considered for the whole system: the year in which all the available information was gathered and analyzed: 2010.

Regarding the periodicity of the assessment, we recommend that it be conducted every 4 or 5 years to balance cost-effectiveness.

\subsection{Development of indicators}

A detailed original profile was developed for each of the 43 effectiveness indicators selected for the complete model (CM) of the SIAPA (Table 1), based on the template developed for other site-level assessment system (Mallarach et al., 2008). The indicators are adaptable to the conditions of any terrestrial protected area, regardless of size, category or type of ecosystem. Some of the indicators are simple ones, representing one variable (e.g. 'evolution of the area designated as protected'), whereas others are composite, including several original variables to represent a complex phenomenon (e.g. 'surface water quality').

Table 1. Template for the development of indicators

\begin{tabular}{|ll|}
\hline Name & \\
\hline Category & Sustainability category or index where the indicator is included \\
Type & Pressure-State-Response \\
Description & Object of the indicator \\
Rationale & Reason/s for which the indicator is important \\
Data source & Body providing data; origin of data \\
Data availability & Ease to access data \\
Updating & Advisable frequency for the updating of the indicator \\
Scale & Scale of valuation: 0 (deficient value), 1 (moderate value), or 2 (adequate value) \\
Calculation & Protocol for the measurement and valuation of the indicator. It may include additional clarifying notes \\
and & as "Explanatory notes" \\
Interpretation & Protocol for the consideration and valuation of the indicator. based on the scale of valuation. It may \\
& include additional clarifying notes as "Explanatory notes" \\
Trend & Criteria which determine the temporal evolution of the indicator \\
References & Bibliography or legislation justifying the selection or valuation of the indicator \\
\hline
\end{tabular}




\subsection{Establishing thresholds}

Two thresholds were chosen for each original scale of every variable, indicator and index according to the following criteria, listed in order of importance: values established by law, values commonly used by specialized agencies and values found in the literature (BarreraRoldán and Saldívar-Valdés, 2002). In the absence of a published reference, logical, empirical or experiencebased values based on the precautionary principle (Cooney and Dickson, 2005) were used to define the necessary thresholds on which to valuate the indicators (ten Brink, 2006; Moldan et al., 2012; Ramírez, 2002).

\subsection{Homogenizing scales}

In order to facilitate integration, interpretation of results and to compare indicator values for different PAs (Bertzky and Stoll- Kleemann, 2009), the original scales for each variable, indicator and index were adapted to a standard scale of valuation of 0 (deficient value), 1 (moderate value) or 2 (adequate value). Similar rescaling procedures have been used in other studies developing indicators or indexes (Chuvieco et al., 2010; Sun et al., 2010).

\subsection{Integration of indicators into indexes}

The 43 indicators were classified according to the internationally accepted pressure-state-response model for environmental indicators (OECD, 1993), rescaled and integrated into six partial indexes summarizing the broad categories defining the effectiveness of a PA that had been previously identified: 'State of Conservation Index' (SCI), 'Planning Index' (PLI), 'Management Index' (MAI), 'Social and Economic Context Index' (SEI), 'Social Perception and Valuation Index' (SPI), and the 'Threats to Conservation Index' (TCI). Two general aggregation procedures were tested: simple and weighted. The simple aggregation procedure assumes that every indicator has the same weight (importance) when integrated into one of the partial indexes. The experts' opinions and our experience showed that this was not a sufficiently justifiable option. Therefore, we opted for weighted aggregation of the indicators, as done in previous studies (Chuvieco et al., 2010; Martínez-Vega et al., 2009). Thus, the 43 indicators were weighted according to the average importance value given by the numerical replies from the experts, excluding the authors: If the sum of the scores of the three experts was 9, the indicator was weighted by 2 points; if the sum of the scores of the three experts was 8 , the indicator was weighted by 1.5 points; if the sum of the scores of the three experts was $<8$, the indicator was weighted by 1 point.

The three indicators included in the SIAPA from the experts' written replies were given an arbitrary weight of 1 point. Thus, each indicator was introduced into the index calculation formula multiplied by the initial average weight given by the expert panel (Martínez-Vega et al., 2009): $1,1.5$ or 2 points. If an indicator could not be measured for some PAs, its value was excluded from the calculation of that index for those PAs. As a result, the indexes of different PAs are compared on the basis of the available information for each PA, which might include different groups and numbers of indicators.

\subsection{Integration of indexes into an effectiveness index}

In order to create a highly aggregated value that summarized the overall effectiveness of each PA for management and policy purposes (Fraser et al., 2006), an 'Effectiveness Index' (EI) was created. A second survey was conducted among the same 12 experts, excluding the authors. The experts were asked to score the six indexes according to their relevance for the effectiveness of a PA1, from 1 point (not very relevant) to 5 points (very relevant). Each of the six partial indexes was subsequently weighted by the average value given by those experts whose replies could be collected: CMAOT, MARM, OSE, ICHN, UCM and EEA (Table 2). The Effectiveness Index was calculated from this survey by summing the five rescaled partial indexes that add to the effectiveness of the protected area: SCI', PLI', MAI', SEI' and SPI', each weighted according to the mean value given by the experts, and subtracting the weighted TCI', which diminishes effectiveness.

For EI valuation and interpretation, cutoffs from the rescaled EI (EI') were empirically established on the basis of the precautionary principle (Cooney and Dickson, 2005) according to the following criteria: EI' $=2$ points (adequate): the upper cutoff is the result of incorporating a value of 1.5 points for each of the first five indexes: SCI, PLI, MAI, SEI and SPI, and 0 points for the TCI: EI' $\geq$ $(1.5 \times 4.3+1.5 \times 3.5+1.5 \times 4.8+1.5 \times 4.2+1.5 \times 3.5-$ $0 \times 4.3) / 24.7=1.2$; EI' $=1$ point (moderate): the lower cutoff is the result of incorporating a value of 1 point for each of the first five indexes: CI, PI, MI, SEI and SPI, and 0 points for the TCI: EI' $\geq(1 \times 4.3+1 \times 3.5+1 \times 4.8+1$ $\times 4.2+1 \times 3.5-0 \times 4.3) / 24.7=0.8$ and $<1.2$; EI $=0$ points (deficient): EI' $<0.8$.

Each index calculation formula and its value and interpretation is shown in Table 3.

\subsection{Optimization of the model}

A simplified model (SM) to enhance the costeffectiveness of the assessment was developed from the complete model (CM) of the SIAPA by further shortlisting the 43 indicators according to the original valuation by the experts, excluding the authors. Indicators summing up to less than 7 points in the original valuation were excluded from the SM. The 'climate change' indicator was included in the SM exceptionally due to its relevance for PA conservation (Araújo et al., 2011). As a result, a simplified set of indicators rep-resenting the most important ones for the effectiveness of PAs was identified. The selected indicators for the SM are marked with (a) in Table 4. 
Table 2.

Index rating given by the experts

\begin{tabular}{|c|c|c|c|c|c|c|}
\hline \multirow[t]{2}{*}{ Expert } & \multicolumn{6}{|l|}{ Index } \\
\hline & $\begin{array}{l}\text { Conservation } \\
\text { state (SCI) }\end{array}$ & $\begin{array}{l}\text { Planning } \\
\text { (PLI) }\end{array}$ & $\begin{array}{l}\text { Management } \\
\text { (MAI) }\end{array}$ & $\begin{array}{l}\text { Social and } \\
\text { economic } \\
\text { context } \\
(\mathrm{SEI})\end{array}$ & $\begin{array}{l}\text { Social perception } \\
\text { and valuation } \\
\text { (SPI) }\end{array}$ & $\begin{array}{l}\text { Threats to } \\
\text { conservation } \\
\text { (TCI) }\end{array}$ \\
\hline СMAOT & 5 & 4 & 5 & 4 & 3 & 4 \\
\hline MARM & 5 & 4 & 5 & 3 & 3 & 5 \\
\hline OSE & 2 & 3 & 5 & 5 & 4 & 4 \\
\hline ICHN & 5 & 3 & 4 & 4 & 3 & 4 \\
\hline UCM & 4 & 3 & 5 & 5 & 5 & 4 \\
\hline EEA & 5 & 4 & 5 & 4 & 3 & 5 \\
\hline MEAN & 4.3 & 3.5 & 4.8 & 4.2 & 3.5 & 4.3 \\
\hline SUM & 24.7 & & & & & \\
\hline
\end{tabular}

CMAOT: Division of PAs of the Regional Ministry of Environment of the Autonomous Region of Madrid; MARM: National Ministry of Environment and Rural and Marine Affairs ; OSE: Spanish Observatory for Sustainability; ICHN: Catalan Institute of Natural History; UCM: Faculty of Biology of the Complutense University of Madrid; EEA: Ecologistas en Acción.

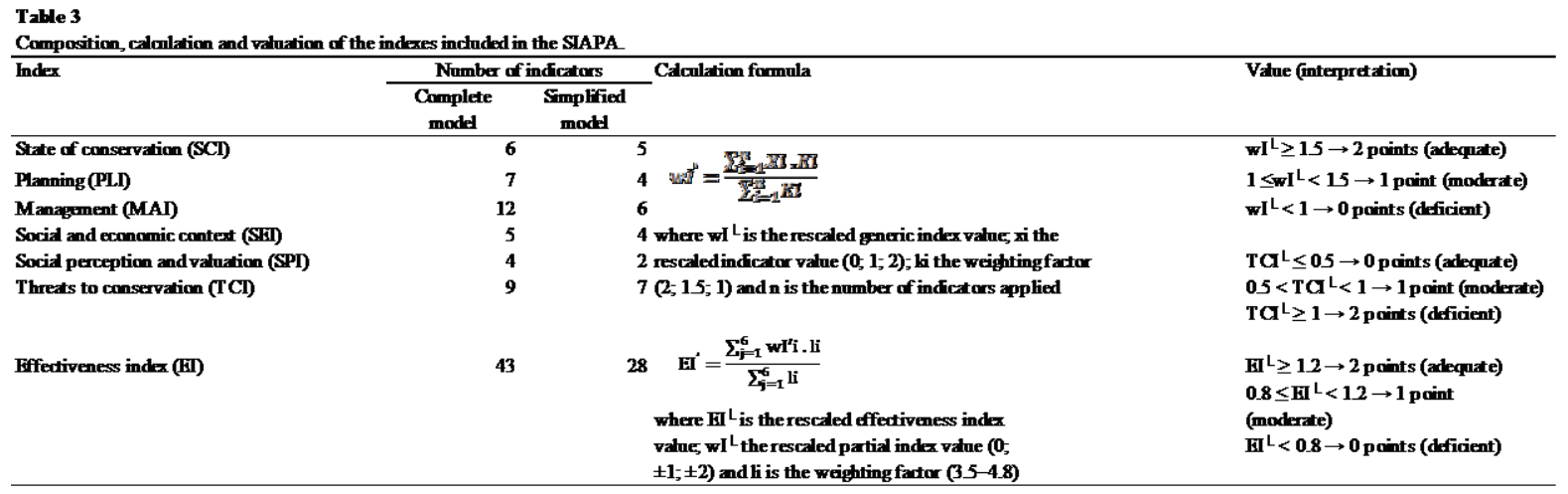

\section{Results}

The 43 indicators making up the CM and the SM of the SIAPA are shown in Table 4.

The detailed profiles of each indicator are provided as supplementary data.

The effectiveness of a PA (EI') can be estimated from the following formula, according to the average weight/contribution of each of the partial indexes to the EI:

$$
\begin{aligned}
\mathrm{EI}^{\prime}=\left(\mathrm{SCI}^{\prime} \times \frac{4.3}{24.7}\right. & +\mathrm{PLI}^{\prime} \times \frac{3.5}{24.7}+\mathrm{MAI}^{\prime} \times \frac{4.8}{24.7} \\
& +\mathrm{SEI}^{\prime} \times \frac{4.2}{24.7}+\mathrm{SPI}^{\prime} \times \frac{3.5}{24.7} \\
& \left.-\mathrm{TCI}^{\prime} \times \frac{4.3}{24.7}\right),
\end{aligned}
$$

or $\mathrm{EI}^{\prime}=\left(\mathrm{SCI}^{\prime} \times 0.176+\mathrm{PLI}^{\prime} \times 0.142+\mathrm{MAI}^{\prime} \times 0.196+\mathrm{SEI}^{\prime} \mathrm{x} 0.169\right.$

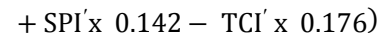

\section{Discussion}

The SIAPA is an environmental decision support system for improving the management and conservation of PAs, primarily for the use of managers and policy-makers. It proposes a scientific definition of 'effectiveness of PAs' and a formula to estimate this parameter simply and comparatively. According to the Effectiveness Index formula, management is the main factor determining the effectiveness of a PA, as suggested by Hockings et al. (2006), whereas planning, and social perception and valuation are the less determinant factors. These results are only partially consistent with other study which has shown that social support is the main factor determining the condition of a PA and its resources (Leverington et al., 2010).

The SIAPA proposes a framework for the horizontal evaluation of individual PAs on common parameters of use for PA managers, conservationists and scientists. It makes it also possible to compare results among different PAs from similar contexts for the use of PA network managers and decision-makers. Comparing PAs on 
Table 4

Indicators included in both models of the SLAPA, category, typ e and standar diz ed weighting fact or given to each indicator by the experts.

\begin{tabular}{|c|c|c|c|}
\hline Indicator & Category & Type & $\begin{array}{l}\text { Weighting } \\
\text { factor }\end{array}$ \\
\hline Evolution of p opulations of endangered species or subsp ecies" & State of conservation & State & 2 \\
\hline Exist ence of up dat ed planning documentsa & Managem ent & Response & 2 \\
\hline Exist ence of up dat ed management documents ${ }^{\circ}$ & Managem ent & Response & 2 \\
\hline L and owner ship ${ }^{\circ}$ & Social and economic context & State & 2 \\
\hline Area affected by fires ${ }^{-}$ & Threats to cons ervation & Pressure & 2 \\
\hline Number of vistors ${ }^{-}$ & Ihreats to cons ervation & Pressure & 2 \\
\hline Zoring & Planning & Response & 1.5 \\
\hline Degree of fulfillment of managem ent objectives ${ }^{*}$ & Managem ent & Response & 1.5 \\
\hline Evolution of investment in the protected area & Managem ent & Response & 1.5 \\
\hline Monitoring activit1es & Managem ent & Response & 1.2 \\
\hline Main economic activities in the protect ed area ${ }^{2}$ & Social and economic context & Pressure & 1.5 \\
\hline L and use changes ${ }^{\circ}$ & Social and economic context & Pressure & 1.5 \\
\hline Perception of the conservation state ${ }^{a}$ & Social perception and valuation & State & 1.5 \\
\hline Economic valuation of the protected area & Social perception and valuation & State & 1.5 \\
\hline Presence of alien invasive species & Ihreats to conservation & Pressure & 1.5 \\
\hline Fragmentation ${ }^{\circ}$ & Threats to cons ervation & Pressure & 1.5 \\
\hline L ocal population density ${ }^{*}$ & Threats to conservation & Pressure & 1.5 \\
\hline Health of veget ation ${ }^{2}$ & State of conservation & St ate & 1 \\
\hline Surface wat er quality & St ate of conservation & St ate & 1 \\
\hline Air quality ${ }^{2}$ cenes & State of conservation & State & 1 \\
\hline Presence of solid waste ${ }^{a}$ & State of conservation & State & 1 \\
\hline L andscape imp act & State of conservation & State & 1 \\
\hline Approp riat eness of protection legislation ${ }^{2}$ & Planning & Response & 1 \\
\hline Exist ence of up dat ed documents on social and economic development & Hlanning & Kesponse & 1 \\
\hline Exist ence of up dat ed documents on public use & Planning & Response & 1 \\
\hline Evolution of the ar ea designated as protect ed & Planning & Response & 1 \\
\hline Degree of characterization of the protected area & Managem ent & Response & 1 \\
\hline Evolution of feature(s) for which the protected ar ea was designated & Managem ent & State & 1 \\
\hline Exist ence of sufticient managem ent statt & Managem ent & Response & 1 \\
\hline Sanctioning procedures & Managem ent & Response & 1 \\
\hline Effectiveness of public participation bodies & Managem ent & Response & 1 \\
\hline Easiness to identify the protected area & Managem ent & Response & 1 \\
\hline Public use intrastructure & Managem ent & Kesponse & 1 \\
\hline Exist ence of enviromm ent al education and volunteering activities & Managem ent & Response & 1 \\
\hline Production and distribution of an annual report on activities and outcomes & Managem ent & Response & 1 \\
\hline Number of municipalities in the protected area & Social and economic context & Pressure & 1 \\
\hline Area provided for the protected area by muricipalities under local Agenda 21 & Social and economic context & Response & 1 \\
\hline Degree of knowledge on the protect ed area & Social perception and valuation & State & 1 \\
\hline Personal importance & Social perception and valuation & St ate & 1 \\
\hline Accessibility ${ }^{*}$ & Threats to conservation & Pressure & 1 \\
\hline Climate change & Threats to cons ervation & Pressure & 1 \\
\hline Isolation & Ihreats to conservation & Pressure & 1 \\
\hline Activities perform ed by visitors & Threats to cons ervation & Pressure & 1 \\
\hline T otal $=43\left(28^{\circ}\right)$ & & & \\
\hline
\end{tabular}

"Indicat ors included in the simplified model.

objective, simple and meaningful bases over time is increasingly demanded (Parrish et al., 2003). However, few such systems have been developed so far. This intermediate PA assessment level complements other levels of evaluation above and below it: PA network assessments and site-specific, goal-oriented assessments.

Regarding the selection of effectiveness categories, we assumed that any PA that is in a good conservation state, has adequate planning, is well managed, has a good socioeconomic context, is positively perceived and valuated by local populations, and has little or no threats will have more chances to conserve its resources in the long-term than other with opposing values.

The SIAPA has been designed to be flexible and adaptable. The development of two models allows adaptation to the circumstances of assessments in term of time and resources needed. Of the two models of the SIAPA developed and tested, the CM should be used when the aim of the assessment is to maximize the amount of information on PAs whereas the SM should be used if the aim is to enhance cost-effectiveness. Once one model is chosen, it should be used consistently, as aggregated results are not directly comparable.

The integration of indicators into indexes and of indexes into a single super-index makes the SIAPA a complete, modular and hierarchical system, from which any result of interest can be extracted at any assessment level: variable, indicator, index or super-index. The integrative nature of the SIAPA allows the assessment of only parts of the complete system (the state of conservation, for instance), individually or comparatively.

The grouping of indicators into clearly defined categories allows precise differentiation between 'management effectiveness' (the MAI) and the evaluation of other parameters, avoiding most limitations of the current PAME concept proposed by Hockings et al. (2000, 2006).

The use of aggregated indexes to convey complex information simply has been pointed out by different studies: Bertzky and Stoll-Kleemann (2009), Fraser et al. 
(2006), Martínez-Vega et al. (2009) and Paleczny and Russell (2005), although they are also considered to oversimplify reality (Spangenberg, 2002). Aggregated results (partial indexes and EI_) should, however, be compared with caution, as different types and numbers of indicators might have been selected for calculating the indexes for different PAs. As a result, whereas indicators' values can be compared directly provided rough data periods are the same, aggregated comparisons among PAs should be interpreted and used more as management guidance than as scientific evidence.

The establishment of reference values for every variable, indicator and index is a clear step forward for sustainability science. The proposed thresholds represent a reference to where we aim to be in terms of sustainability (Moldan et al., 2012; Spangenberg, 2011) and define acceptable ranges of variation (Parrish et al., 2003). They allow making conservation decisions even if current evidence remains incomplete (Pullin, 2002; Spangenberg, 2011). When establishing thresholds or cutoffs we always considered the irreplaceable character of many of the features protected by PAs. Therefore, in absent of references we established exigent thresh-olds based on the precautionary principle (Cooney and Dickson, 2005) instead of more standard ones such as quartiles. That is why lower cutoffs are usually wider than upper ones. However, further research is needed to ensure the ecological basis of selected thresholds, variables, indicators, indexes and their relationships, according to the biophysical properties of the system (Moldan et al., 2012). Ecological models can notably help achieving this target (Parrish et al., 2003).

The SIAPA was developed in a participatory way, with 12 institutions contacted to provide input. Eight of these provided some form of collaboration, with remarkable input from six of them, including the managers of the PAs of the Autonomous Region of Madrid (CMAOT) as potential main users of the system. Although participation was limited because it was voluntary (Spangenberg, 2011), it can be considered to be adequately representative in comparison with most assessment systems worldwide (Chape et al., 2008).

Even though numerous experts gave their views on different parts of the SIAPA, it is a pilot system, which can and should be improved. Some indicators might have to be included in and/or excluded from both models as a result of new knowledge, as indicator selection is one of the most sensitive steps in environmental assessments (Moldan et al., 2012). Thresholds should be redefined for some variables in the light of new evidence or normative changes (Rametsteinera et al., 2011). Some of the indicators or indexes might have to be recalculated or weighted differently to perfect the system (Pomeroy et al., 2005) or to adapt it to other contexts.

Although it was conceived with a wide scope, the SIAPA was developed within particular temporal (2009), social (European) and bio-geographical (Mediterranean) contexts. It analyses the parameters considered to be more important within these contexts. Therefore, adaptations should be considered when replicating this system. The proposed indicators, thresholds and weighting factors might need to be adapted to the biophysical, geographical, legal and socioeconomic contexts of the places where it will be implemented to be fully meaningful. Conducting ad hoc surveys among local experts previous to the implementation of the system in different contexts should help redefining these aspects.

Finally, the development and inclusion of complementary marine and coastal indicators in the SIAPA would make it useable for assessing most types of PAs.

\section{Conclusion}

The SIAPA is a promising new tool for assessing the effectiveness of PAs in an integrated manner. The overall characteristics of the SIAPA (namely its focus and its integrated, modular, hierarchical, numerical and comparative structure) make it different from other PA assessment systems. It accomplishes most of the desired characteristics of sustainability science (Spangenberg, 2011): it is purpose-bound, it provides an integrated assessment, and it was developed in an interdisciplinary way, getting input from sciences (social and natural) as well as from empirical experience.

The current environmental crisis calls for immediate action to attain more sustainable ways of human development. The SIAPA has been developed to become one of such actions

\section{Acknowledgements}

The authors would like to thank all those who contributed to this paper. We would like to acknowledge the expert panel and all the people in the various institutions and administrations who provided data and advice on conducting the assessment, especially the staff of the Ministry of Environment of the Autonomous Region of Madrid. We would also like to thank David Riaño Arribas, Spanish National Research Council, Alain Jeudy de Grissac, IUCN Centre for Mediterranean Cooperation, Elizabeth Heseltine and the anonymous reviewers for their useful remarks on the different drafts of this paper. This study was funded by a JAE doctoral grant from the Spanish National Research Council.

\section{Appendix A. Supplementary data}

Supplementary data associated with this article can be found, in the online version, at http://dx.doi.org/10.1016/j. ecolind.2012.05.009.

\section{References}

Alcaraz-Segura, D., Cabello, J., Paruelo, J.M., Delibes, M., 2009. Use of descriptors of ecosystem functioning for monitoring a national park network: a remote sensing approach. Environ. Manage. 43, 38-48. 
Araújo, M.B., Alagador, D., Cabeza, M., Nogués-Bravo, D., Thuiller, W., 2011. Climate change threatens European conservation areas. Ecol. Lett. 14, 484-492.

Barrera-Roldán, A., Saldívar-Valdés, A., 2002. Proposal and application of a sustainable development index. Ecol. Indic. 2, 251-256.

Bertzky, M., Stoll-Kleemann, S., 2009. Multi-level discrepancies with sharing data on protected areas: what we have and what we need for the global village. J. Environ. Manage. 90, 8-24.

ten Brink, B., 2006. Indicators as communication tools: an evolution towards composite indicators. A Long-Term Biodiversity, Ecosystem and Awareness Research Network. ALTER-Net. http://www.globio.info/downloads/79/Report++ten+Brink+\%282006\%29+Indicators+as+communication+t ools-.pdf (accessed November 2011).

Butchart, S.H.M., Walpole, M., Collen, B., van Strien, A., Scharlemann, J.P.W., Almond, R.E.E., Baillie, J.E.M., Bomhard, B., Brown, C., Bruno, J., Carpenter, K.E., Carr, G.M., Chanson, J., Chenery, A.M., Csirke, J., Davidson, N.C., Dentener, F., Foster, M., Galli, A., Galloway, J.N., Genovesi, P., Gregory, R.D., Hockings, M., Kapos, V., Lamarque, J.-F., Leverington, F., Loh, J., McGeoch, M.A., McRae, L., Minasyan, A., Morcillo, M.H., Oldfield, T.E.E., Pauly, D., Quader, S., Revenga, C., Sauer, J.R., Skolnik, B., Spear, D., Stanwell-Smith, D., Stuart, S.N., Symes, A., Tierney, M., Tyrrell, T.D., Vié, J.C., Watson, R., 2010. Global biodiversity: indicators of recent declines. Science 328, 1164-1168.

CBD, 2010. Covention on Biological Diversity. COP 10 Decision $\mathrm{X} / 31$ Protected areas. http://www.cbd.int/decision/cop/?id=12297 (accessed February 2012)

Chape, S., Spalding, M., Jenkins, M.D., 2008. The World's Protected Areas: Status, Values and Prospects in the 21st Century. Prepared by the UNEP World Conservation Monitoring Centre. University of California Press, Berkeley, USA.

Chuvieco, E., Aguado, I., Yebra, M., Nieto, H., Salas, J., Martín, M.P., Vilar, L., Martínez, J., Martín, S., Ibarra, P., de la Riva, J., Baeza, J., Rodríguez, F., Molina, J.R., Herrera, M.A., Zamora, R., 2010. Development of a framework for fire risk assessment using remote sensing and geographic information system technologies. Ecol. Model. 221, 46-58.

Cooney, R., Dickson, B. (Eds.), 2005. Risk and Uncertainty in Conservation and Sustainable Use. Earthscan, London.

Dudley, N. (Ed.), 2008. Guidelines for Applying Protected Area Management Categories. IUCN: Gland, Switzerland.

EEA, 1999. European Environment Agency. Environmental indicators: Typology and Overview. Technical Report No. 25. Office for Official Publications of the European Communities. Luxembourg.

Ervin, J., 2003. Protected area assessment in perspective. Bioscience 53, 819-822.

Fraser, E.D.G., Dougill, A.J., Mabee, W.E., Reed, M., McAlpine, P., 2006. Bottom up and top down: analysis of participatory processes for sustainability indicator identification as a pathway to community empowerment and sustainable environmental management. J. Environ. Manage. 78, 114127.

Gaston, K.J., Charman, K., Jackson, S.F., Armsworth, P.R., Bonn, A., Briers, R.A., Callaghan, C.S.Q., Catchpole, R., Hopkins, J., Kunin, W.E., Latham, J., Opdam, P., Stoneman, R., Stroud, D.A., Tratt, R., 2006. The ecological effectiveness of protected areas: the United Kingdom. Biol. Conserv 132, 7687.

Hockings, M., Stolton, S., Dudley, N., 2000. Evaluating Effectiveness: A Framework for Assessing the Management of Protected Areas. Best Practice Protected Area Guidelines Series No. 6. IUCN, Gland, Switzerland and Cambridge, UK.

Hockings, M., Stolton, S., Leverington, F., Dudley, N., Courrau, J., 2006. Evaluating effectiveness. In: A Framework for Assessing Management Effectiveness of Protected Areas, second ed. IUCN, Gland, Switzerland, and Cambridge, UK.

Jameson, S.C., Tupper, M.H., Ridley, J.M., 2002. The three screen doors: can marine 'protected' areas be effective? Mar. Pollut. Bull. 44, 1177-1183.

Jenkins, C.N., Joppa, L., 2009. Expansion of the global terrestrial protected area system. Biol. Conserv. 142, 2166-2174.

Jiménez, L., Prieto, F., Riechmann, J., Gómez-Sal, A. (Coord.), 2005. Sostenibilidad en España 2005. Informe de Primavera. Observatorio de la Sostenibilidad en España, Alcalá de Henares, Spain.

Leverington, F., Lemos, K., Courrau, J., Pavese, H., Nolte, C. Marr, M., Coad, L., Burguess, N., Bomhard, B., Hockings, M., 2010. Management Effectiveness Evaluation in Protected Areas - a Global Study, second ed. University of Queensland, Brisbane, Australia.

Mallarach, J.M., Germain, J., Sabaté, X., Basora, X., 2008 Protegits de fet o de dret? Primera avaluació del sistema d'espais naturals protegits de Catalunya. Institució Catalana d'Història Natural. http://ichn.iec.cat /Avaluaci\%C3\%B3\%20d\%27espais.htm Accessed October 2011

Martínez-Vega, J., Echavarría, P., González-Gascón, V., Martínez-Cruz, N., 2009. Propuesta metodológica para el análisis de la sostenibilidad en la provincia de Cuenca. Bol AGE 49, 281-308.

McDonald, R.I., Boucher, T.M., 2011. Global development and the future of the protected area strategy. Biol. Conserv. 144 383-392.

Moldan, B., Janousková, S., Hák, T., 2012. How to understand and measure environmental sustainability: indicators and targets. Ecol. Indic. 17, 4-13.

Naughton-Treves, L., Buck, M., Brandon, K., 2005. The role of protected areas in conserving biodiversity and sustaining local livelihoods. Annu. Rev. Environ. Resour. 30, 219-252.

Nolte, C., Leverington, F., Kettner, A., Marr, M., Nielsen, G., Bomhard, B., Stolton, S., Stoll-Kleemann, S., Hockings, M., 2010. Protected area management effectiveness assessments in Europe. In: A Review of Application, Methods and Results. University of Greifswald, Germany.

OECD, 1993. OECD Core Set of Indicators for Environmental Performance Reviews: A Synthesis Report by the Group on the State of the Environment. OECD, Paris.

Ostendorf, B., 2011. Overview: spatial information and indicators for sustainable management of natural resources. Ecol. Indic. 11, 97-102.

Paleczny, D.R., Russell, S., 2005. Participatory Approaches in protected area assessment and reporting. In: Proceedings of the Parks Research Forum of Ontario, University of Guelph, Canada.

Parrish, J.D., Braun, D.P., Unnasch, R.S., 2003. Are we conserving what we say we are? Measuring ecological Integrity within protected areas. Bioscience 53, 851-860.

Pomeroy, R.S., Watson, L.M., Parks, J.E., Cid, G.A., 2005. How is your MPA doing? A methodology for evaluating the management effectiveness of marine protected areas. Ocean Coast. Manage. 48, 485-502.

Pullin, A.S., 2002. Conservation Biology. Cambridge University Press, Cambridge, UK

Radeloff, V.C., Stewart, S.I., Hawbaker, T.J., Gimmi, U. Pidgeon, A.M., Flather, C.H., Hammer, R.B., Helmers, D.P., 2010. Housing growth in and near United States protected areas limits their conservation value. PNAS 107, 940-945. 
Rametsteinera, E., Pülzlb, H., Alkan-Olssonc, J., Frederiksend, P., 2011. Sustainability indicator development - science or political negotiation? Ecol. Indic. 11, 61-70.

Ramírez, L. (Coord.)., 2002. Indicadores ambientales. Situación actual y perspectivas. Organismo Autónomo Parques Nacionales. Ministerio de Medio Ambiente, Madrid.

Spangenberg, J.H., 2002. Environmental space and the prism of sustainability: frameworks for indicators measuring sustainable development. Ecol. Indic. 2, 295-309.

Spangenberg, J.H., 2011. Sustainability science: a review, an analysis and some empirical lessons. Environ. Conserv. 38, 275-287.
Spellerberg, I.F., 1992. Evaluation and Assessment for Conservation. Chapman \& Hall, London, UK.

Stoll-Kleemann, S., 2010. Evaluation of management effectiveness in protected areas: methodologies and results. Basic Appl. Ecol. 11, 377-382.

Sun, L., Ni, J., Borthwick, A.G.L., 2010. Rapid assessment of sustainability in Mainland China. J. Environ. Manage. 91, 1021-1031 


\section{Indicators used in the SIAPA}

\section{State of conservation: six indicators}

\begin{tabular}{|c|c|}
\hline \multicolumn{2}{|c|}{ 1.1. Evolution of populations of endangered species or subspecies } \\
\hline Category & State of conservation \\
\hline Type & State \\
\hline Description & $\begin{array}{l}\text { This indicator assesses the evolution in numbers of the populations of } \\
\text { endangered species or subspecies dwelling within the protected area } \\
\text { with a category of threat established in an official or scientific register as } \\
\text { (EN) or (CR) }\end{array}$ \\
\hline Rationale & $\begin{array}{l}\text { The main purpose of protected areas is nature conservation (Múgica } e t \\
\text { al. 2009), especially of threatened biodiversity at the genetic, specific } \\
\text { and ecosystem levels. The dynamics of threatened species populations } \\
\text { must be monitored in particular, because of their fragility (Atauri et al., } \\
\text { 2002). Although the existence of species or subspecies registered as } \\
\text { (EN) or (CR) in a protected area indicates a good conservation state, the } \\
\text { temporal evolution of their populations is crucial, as it is related to } \\
\text { management effectiveness. This parameter is therefore usually used to } \\
\text { assess the effectiveness of a protected area (Pomeroy et al., 2005). It is } \\
\text { also one of the criteria used to assess the favourable conservation state of } \\
\text { the species included in the annexes of the Habitats Directive (Walder } e t \\
\text { al., 2006). An increase or stabilization of those populations implies an } \\
\text { adequate conservation state, whereas a decrease in the number of } \\
\text { individuals of those species or subspecies indicates degradation of the } \\
\text { characteristics of the protected area. Thus, both tendencies suggest a } \\
\text { response of biodiversity to the conservation state of the area }\end{array}$ \\
\hline Data source & Official register \\
\hline Data availability & \\
\hline Updating & Annually \\
\hline Scale & Ordinal scale, from 0 to 2 \\
\hline $\begin{array}{l}\text { Calculation and } \\
\text { interpretation }\end{array}$ & $\begin{array}{l}\text { The analysis period will be as long as possible; if possible, since the date } \\
\text { of designation of the protected area. At a minimum, data for } 3 \text { years, not } \\
\text { spaced over } 2 \text { years (at regular annual or } 2 \text {-yearly intervals), up to the } \\
\text { most recent date will be considered. The most recent date must not be } \\
\text { earlier than } 2 \text { years before the assessment year. The assessment period } \\
\text { will be split into three equal intervals. } \\
\text { The temporal evolution of the endangered populations will be } \\
\text { considered: } \\
\text { - Positive: if their populations counted by census or estimated by } \\
\text { sampling, maintain an increasing trend in numbers: }>5 \% \\
\text { between the initial and the intermediate year and between the } \\
\text { intermediate and the final year. A score of } 2 \text { points will be } \\
\text { given. } \\
\text { Stable: if their populations counted by census or estimated by } \\
\text { sampling, do not vary notably: } \pm 5 \% \text { of the average population } \\
\text { size between the two periods or they are }<5 \% \text { in the } \\
\text { intermediate year but }>5 \% \text { in the final year in relation to the } \\
\text { initial year. A score of } 1 \text { point will be given. }\end{array}$ \\
\hline
\end{tabular}




\begin{tabular}{|c|c|}
\hline & $\begin{array}{l}\text { - Negative: if their populations counted by census or estimated by } \\
\text { sampling, maintain a decreasing trend: }<5 \% \text { between the initial } \\
\text { and the intermediate year and between the intermediate and the } \\
\text { final year. A score of } 0 \text { points will be given. } \\
\text { The total value of the indicator (X) for each protected area will be the } \\
\text { average score for each of the values for each species or subspecies that } \\
\text { thrive in that protected area: } \\
\text { - } \mathrm{X} \geq 1.5 \rightarrow 2 \text { points } \\
\text { - } \quad 1.5>\mathrm{X} \geq 1 \rightarrow 1 \text { point } \\
\text { - } \mathrm{X}<1 \rightarrow 0 \text { points } \\
\text { Explanatory notes } \\
\text { When there are different (EN) or (CR) species or subspecies in the } \\
\text { protected area, the results will be shown individually for each in a table. } \\
\text { Then, scores for each species or subspecies will be added and divided by } \\
\text { the number of species or subspecies. } \\
\text { Because of the importance of this parameter for biodiversity } \\
\text { conservation, when any of the species or subspecies scores } 0 \text {, the value } \\
\text { of } X \text { will always be } 0 \text { points, if at the same time there are not two or } \\
\text { more species or subspecies with positive trends (with updated data } \leq 2 \\
\text { years old). In this case, } X \text { will be } 1 \text { point. } \\
\text { In any case, lack of data on any (EN) or (CR) species or subspecies, } \\
\text { outdated data ( }>2 \text { years old) or a negative trend for two or more species } \\
\text { or subspecies in the same protected area will entail an X of } 0 \text { points. } \\
\text { 'Presence/absence' data are not scored. Therefore, they will be } \\
\text { considered 'Not applicable' and valued } 0 \text { points. }\end{array}$ \\
\hline Tendency & $\begin{array}{l}\text { The tendency of the indicator will be positive if all the (EN) or (CR) } \\
\text { species or subspecies populations increase in numbers, whatever the } \\
\text { magnitude of the increase. } \\
\text { The tendency of the indicator will be positive if the number of } \\
\text { individuals of (EN) or (CR) species or subspecies oscillates within } \pm 5 \% \\
\text { in the three measurement years. } \\
\text { The tendency of the indicator will be negative if all the (EN) or (CR) } \\
\text { species or subspecies populations decrease in numbers between the two } \\
\text { analysed periods, whatever the magnitude of this decrease. } \\
\text { The tendency will be considered 'Not applicable' if different (EN) or } \\
\text { (CR) species or subspecies populations have opposite trends or if data } \\
\text { are presented as 'presence/absence'. }\end{array}$ \\
\hline References & $\begin{array}{l}\text { - Ley 42/2007, de } 13 \text { de diciembre, del Patrimonio Natural y de la } \\
\text { Biodiversidad. Arts. 47, 53.3, 53.4, 55.1, 55.3, } 56.1 \text { y } 56.2 \text {. } \\
\text { Ley } 2 / 1991 \text {, de } 14 \text { de febrero, para la Protección de la Fauna y la Flora } \\
\text { Silvestres en la Comunidad de Madrid. Arts. } 6 \text { y } 7 \text {. } \\
\text { Real Decreto } 439 / 1990, \text { de } 30 \text { de marzo, por el que se regula el } \\
\text { Catálogo Nacional de Especies Amenazadas. Arts. 3, } 6.2 \text { y } 7.2 \text {. } \\
\text { Actualizaciones. } \\
\text { Decreto } 18 / 1992 \text {, de } 26 \text { de marzo, por el que se aprueba el Catálogo } \\
\text { Regional de Especies Amenazadas de Fauna y Flora Silvestres y se } \\
\text { crea la Category de árboles singulares. Arts. 2.1, } 5 \text { y Anexo único } \\
\text { (excepto 2.E). } \\
\text { Atauri, J.A.; de Lucio. J.V. y Castell, C. 2002. El papel de los } \\
\text { indicadores en la gestión de los espacios naturales protegidos. En } \\
\text { Ramírez, L. (Coord.). Indicadores ambientales. Situación actual y } \\
\text { perspectivas. Organismo Autónomo Parques Nacionales. Madrid. }\end{array}$ \\
\hline
\end{tabular}




\begin{tabular}{|l|l|}
\hline & Pomeroy, R.S., Parks, J.E.; and Watson, L.M. 2005. How is your MPA \\
& doing? A methodology for evaluating the management effectiveness of \\
& marine protected areas. IUCN, Gland, Switzerland, and Cambridge, \\
& United Kingdom. \\
& Walder, C.; Dick, G.; Baumüller, A.; and Weatherley, J. 2006. \\
& Towards European Biodiversity Monitoring. Assessment, monitoring \\
& and reporting of conservation status of European habitats and species. \\
& European Habitats Forum. Wien, Cambridge, Brussels. \\
& Mallarach, J.M.; Germain, J.; Sabaté, X.; y Basora, X. 2008. Protegits \\
& de fet o de dret? Primera avaluació del sistema d'espais naturals \\
& protegits de Catalunya. Institució Catalana d'Història Natural. \\
& Disponible en: \\
http://ichn.iec.cat/Avaluaci\%C3\%B3\%20d\%27espais.htm & Múgica, M.; Martínez-Alandi, C.; Gómez-Limón, J.; Puertas, J.; \\
Atauri, J.A.; y De Lucio, J.V.. 2009. Anuario EUROPARC-España del \\
estado de los espacios naturales protegidos 2009. Fundación Fernando \\
González Bernáldez. Madrid.
\end{tabular}

\begin{tabular}{|c|c|}
\hline \multicolumn{2}{|c|}{ 1.2. Health of vegetation } \\
\hline Category & State of conservation \\
\hline Type & State \\
\hline Description & $\begin{array}{l}\text { This indicator assesses the changes in the defoliation and decoloration of } \\
\text { trees. These changes may be due to air pollution, fires, human activities, } \\
\text { plant diseases or adverse soil or weather conditions }\end{array}$ \\
\hline Rationale & $\begin{array}{l}\text { The health of vegetation is seen in parameters such as decoloration, } \\
\text { defoliation or deterioration. In the Mediterranean area, defoliation is } \\
\text { considered to be an accurate indicator of 'forest damage' (VVAA, } \\
\text { 1996). Defoliation thresholds are established by agreement (EU, } \\
\text { UNECE), as no physiological thresholds have been defined yet (Lorenz } \\
\text { et al., 2007) }\end{array}$ \\
\hline \multicolumn{2}{|l|}{ Data source } \\
\hline \multicolumn{2}{|l|}{ Data availability } \\
\hline Updating & Annually \\
\hline Scale & Ordinal scale, from 0 to 2 \\
\hline $\begin{array}{l}\text { Calculation and } \\
\text { interpretation }\end{array}$ & $\begin{array}{l}\text { The following parameters will be measured for the last year for which } \\
\text { data are available. They will be considered and valuated as follows: } \\
\text { - Defoliation }(\mathrm{X}) \\
\text { Null: if } \mathrm{X} \leq 10 \% \rightarrow 2 \text { points } \\
\text { Moderate: if } 10 \%<\mathrm{X} \leq 25 \% \rightarrow 1 \text { point } \\
\text { High: if } \mathrm{X}>25 \% \rightarrow 0 \text { points } \\
\text { Decoloration }(\mathrm{Y}) \\
\text { Null: if } \mathrm{Y} \leq 10 \% \rightarrow 2 \text { points } \\
\text { Moderate: if } 10 \%<\mathrm{Y} \leq 25 \% \rightarrow 1 \text { point } \\
\text { High: if } \mathrm{Y}>25 \% \rightarrow 0 \text { points } \\
\text { If there are different plots within a protected area, a simple average of } \\
\text { the scores for the two parameters will be used for the year considered. } \\
\text { The health of vegetation will be the average of the two parameters }(\mathrm{Z}) \text {. } \\
\text { It will be considered and valuated as follows: }\end{array}$ \\
\hline
\end{tabular}




\begin{tabular}{|c|c|}
\hline & $\begin{array}{ll}\text { - } & \text { Adequate: if } Z>1.5 \rightarrow 2 \text { points } \\
\text { - } & \text { Moderate: if } 1.5 \leq Z \leq 1 \rightarrow 1 \text { point } \\
\text { - } & \text { Deficient: if } Z<1 \rightarrow 0 \text { points }\end{array}$ \\
\hline Tendency & $\begin{array}{l}\text { The tendency will be measured by subtracting the average defoliation } \\
\text { and decoloration values (in percentages) for the last } 2 \text { years assessed }(\mathrm{H}) \\
\text { from the average values for the two parameters (also in percentages) for } \\
\text { the } 5 \text { years previous to the last } 2 \text { years }(\mathrm{K}) \text {. } \\
\text { The tendency will be positive if } \mathrm{H}<\mathrm{K} \text {, stable if } \mathrm{H}=\mathrm{K} \text {, and negative if } \\
\mathrm{H}>\mathrm{K} \text {. }\end{array}$ \\
\hline References & $\begin{array}{l}\text { - VVAA. 1996. Sistema español de indicadores ambientales: subáreas } \\
\text { de biodiversidad y bosque. Ministerio de Medio Ambiente. Madrid. } \\
\text { Lorenz, M.; Fischer, R.; Becher, G.; Granke, O.; Roskams, P.; Nagel, } \\
\text { H.D.; and Kraft, P. 2007. Forest Condition in Europe. 2007 Technical } \\
\text { Report of ICP Forests. Federal Research Centre for Forestry and } \\
\text { Forest Products \& Department of Wood Science, University of } \\
\text { Hamburg. Hamburg. } \\
\text { - International Co-operative Programme on Assessment and Monitoring } \\
\text { of Air Pollution Effects on Forests. En: http://www.icp-forests.org/ }\end{array}$ \\
\hline
\end{tabular}

\begin{tabular}{|c|c|}
\hline \multicolumn{2}{|c|}{ 1.3. Surface water quality } \\
\hline Category & State of conservation \\
\hline Type & State \\
\hline Description & $\begin{array}{l}\text { This indicator assesses the state and evolution of different parameters } \\
\text { affecting the quality of surface waters (water masses or water courses), } \\
\text { which may also influence living organisms }\end{array}$ \\
\hline Rationale & $\begin{array}{l}\text { Surface waters are the living environment for many organisms. They are } \\
\text { also a vital need for all of them. Surface waters are present in numerous } \\
\text { ecosystems and protected areas. Many organisms and ecosystems (some } \\
\text { of which are endangered) depend on adequate water quality. As a result, } \\
\text { evaluating the quality of surface waters is relevant to determining the } \\
\text { state of conservation of protected areas (Pomeroy et al., 2005; Mallarach } \\
\text { et al., 2008; VVAA, 2008) }\end{array}$ \\
\hline \multicolumn{2}{|l|}{ Data source } \\
\hline \multicolumn{2}{|l|}{ Data availability } \\
\hline Updating & Annually \\
\hline Scale & Ordinal scale, from 0 to 2 \\
\hline $\begin{array}{l}\text { Calculation and } \\
\text { interpretation }\end{array}$ & $\begin{array}{l}\text { The annual average values of the following parameters will be measured } \\
\text { from a minimum of two non-consecutive quarterly values, in surface } \\
\text { water masses and courses, since the designation date of the protected } \\
\text { area or the first available data, up to the last available annual value. They } \\
\text { will be valuated as follows: } \\
\text { 1. Dissolved oxygen (DO): } \\
\text { - If [DO] }>5 \mathrm{mg} / \mathrm{l}: 1 \text { point } \\
\text { - If [DO] } \leq 5 \mathrm{mg} / \mathrm{l}: 0 \text { points } \\
\text { 2. 5-year biochemical oxygen demand }\left(\mathrm{BOD}_{5}\right) \text { : } \\
\text { - If } \mathrm{BOD}_{5}<6 \mathrm{mg} / \mathrm{l}: 1 \text { point } \\
\text { - If } \mathrm{BOD}_{5} \geq 6 \mathrm{mg} / \mathrm{l}: 0 \text { points } \\
\text { 3. pH: } \\
\text { - If } \mathrm{pH}: 6<\mathrm{pH}<9: 1 \text { point }\end{array}$ \\
\hline
\end{tabular}




\begin{tabular}{|c|c|}
\hline & 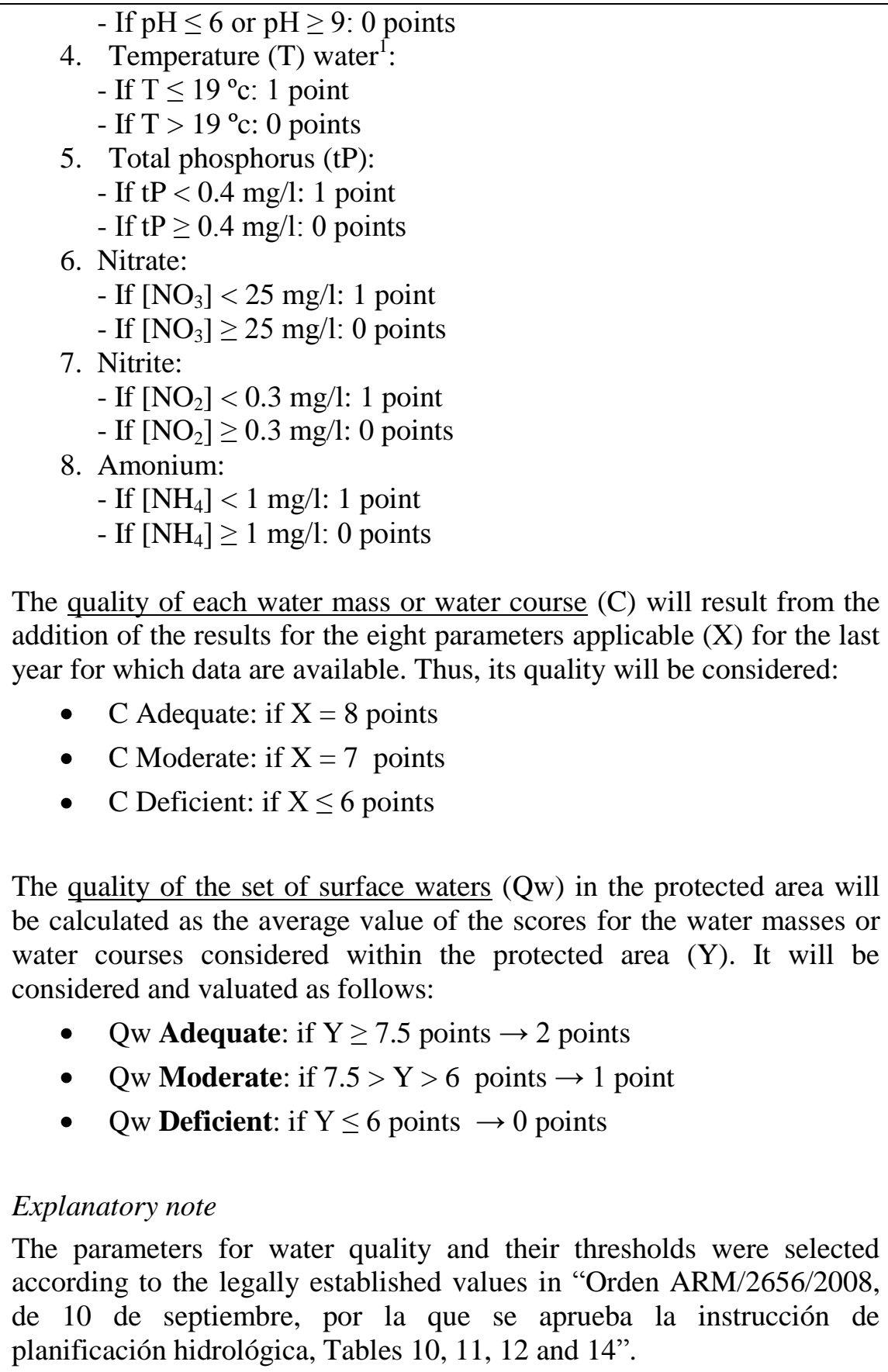 \\
\hline Tendency & $\begin{array}{l}\text { The tendency will be measured by comparing the Qw value for the last } \\
\text { year analysed with the Qw value for the previous year analysed. } \\
\text { Whenever possible, the comparison will be made with the year } \\
\text { inmediately before the last year analysed. }\end{array}$ \\
\hline References & 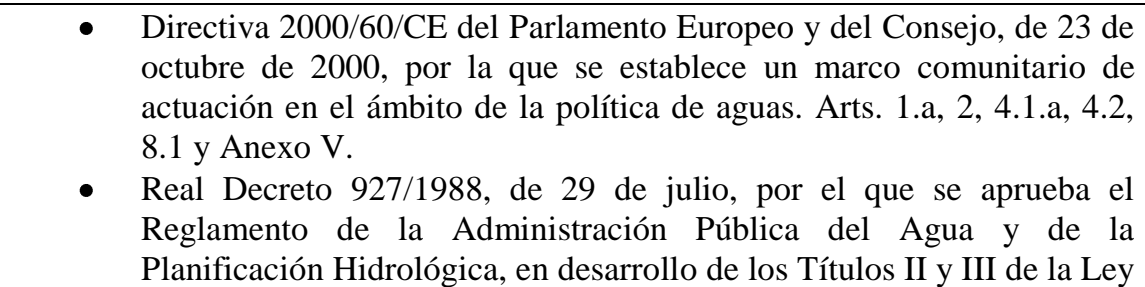 \\
\hline
\end{tabular}

\footnotetext{
${ }^{1}$ Reference value calculated from the application of a $+10 \%$ to the highest value of the analysed data set from surface waters in the Autonomous Region of Madrid $\left(17.5^{\circ} \mathrm{c}\right)$.
} 


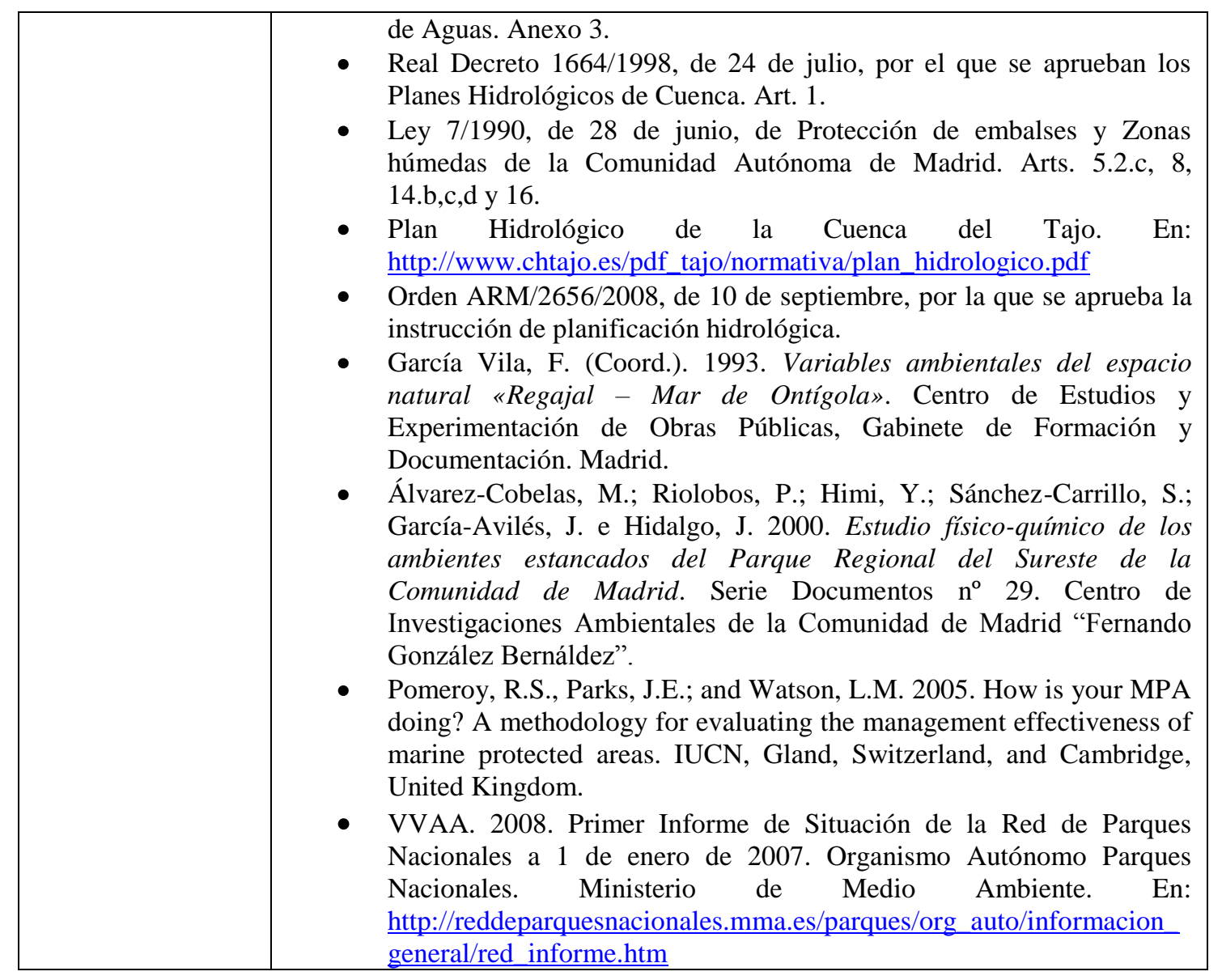

\begin{tabular}{|c|c|}
\hline \multicolumn{2}{|l|}{ 1.4. Air quality } \\
\hline Category & State of conservation \\
\hline Type & State \\
\hline Description & $\begin{array}{l}\text { This indicator assesses the state and evolution of the immission levels of } \\
\text { different air pollutants affecting living organisms }\end{array}$ \\
\hline Rationale & $\begin{array}{l}\text { High concentrations of air pollutants in the lower atmosphere can have } \\
\text { negative impacts on living organisms (mainly vegetation), materials and } \\
\text { human health (UN, 2007). It is therefore highly advisable to monitor } \\
\text { basic determinants of adequate air quality continuously in particularly } \\
\text { sensitive areas,such as protected areas }\end{array}$ \\
\hline \multicolumn{2}{|l|}{ Data source } \\
\hline \multicolumn{2}{|l|}{ Data availability } \\
\hline Updating & Annually \\
\hline Scale & Ordinal scale, from 0 to 2 \\
\hline $\begin{array}{l}\text { Calculation and } \\
\text { interpretation }\end{array}$ & $\begin{array}{l}\text { Limit or target values for the protection of vegetation and/or ecosystems } \\
\text { will be measured according to current legislation for the parameters } \mathrm{SO}_{2} \text {, } \\
\mathrm{NO}_{\mathrm{x}} \text { and } \mathrm{O}_{3} \text {, or those available among these ones, depending on the air } \\
\text { control station. } \\
\text { Limit values per pollutant substance: } \\
\quad \text { - } \mathrm{SO}_{2}: 20 \mu \mathrm{g} / \mathrm{m}^{3} \text { civil year plus winter (no tolerance) }\end{array}$ \\
\hline
\end{tabular}




\begin{tabular}{|c|c|}
\hline & $\begin{array}{l}\text { - } \mathrm{NO}_{\mathrm{x}} \text { : } 30 \mu \mathrm{g} / \mathrm{m}^{3} \text { civil year plus winter (no tolerance) } \\
\quad \mathrm{O}_{3} \text { (AOT } 40 \text { ): } 18000 \mu \mathrm{g} / \mathrm{m}^{3} \cdot \mathrm{h} \text { as a } 3 \text { - or } 5 \text {-year average } \\
\text { Average annual values for the three parameters will be chosen for the } \\
\text { available air control stations for the last year for which data are } \\
\text { available. Their values will be interpolated on a GIS raster map of the } \\
\text { area using the 'Spline Tension' method. Then, the average concentration } \\
\text { of each parameter in each protected area will be calculated. } \\
\text { Each parameter will be valuated from } 0 \text { to } 2 \text { points as follows: } \\
\text { - NO } \mathrm{N}_{\mathrm{x}} \text { : } \\
\text {-If the annual average value is }>30 \mu \mathrm{g} / \mathrm{m}^{3} \text {, the value will be } 0 \text { points. } \\
\text {-If the annual average value is } 20-30 \mu \mathrm{g} / \mathrm{m}^{3} \text {, the value will be } 1 \text { point.. } \\
\text {-If the annual average value is }<20 \mu \mathrm{g} / \mathrm{m}^{3} \text {, the value will be } 2 \text { points. } \\
\text { - SO }{ }_{2} \text { : } \\
\text {-If the annual average value is }>20 \mu \mathrm{g} / \mathrm{m}^{3} \text {, the value will be } 0 \text { points. } \\
\text {-If the annual average value is } 10^{1}-20 \mu \mathrm{g} / \mathrm{m}^{3} \text {, the value will be } 1 \text { point. } \\
\text {-If the annual average value is }<10 \mu \mathrm{g} / \mathrm{m}^{3} \text {, the value will be } 2 \text { points. } \\
\text { - } \mathrm{O}_{3} \text { : } \\
\text {-If the annual average value is over } 18000\left(\mu \mathrm{g} / \mathrm{m}^{3}\right) \mathrm{h} \text {, the value of the } \\
\text { parameter will be } 0 \text { points. } \\
\text {-If the annual average value is } 6,000-18000\left(\mu \mathrm{g} / \mathrm{m}^{3}\right) \mathrm{h} \text {, the value will } \\
\text { be } 1 \text { point. } \\
\text {-If the annual average value is }<6,000\left(\mu \mathrm{g} / \mathrm{m}^{3}\right) \mathrm{h} \text {, the value will be } 2 \\
\text { points. }\end{array}$ \\
\hline Tendency & $\begin{array}{l}\text { The tendency will be measured by comparing the values for the three } \\
\text { variables for the last year analysed and the previous year for which data } \\
\text { are available, ideally the year immediately before the last year analysed. } \\
\text { If the value of each variable in the last year is larger than their value in } \\
\text { the previous year, } 1 \text { point will be subtracted. If the value is smaller than } \\
\text { the previous value, } 1 \text { point will be added. If the value is the same, } 0\end{array}$ \\
\hline
\end{tabular}




\begin{tabular}{|c|c|}
\hline & $\begin{array}{l}\text { points will be added. The tendency between the two years analysed will } \\
\text { be obtained by the simple addition of the results for the three variables, } \\
\text { with possible values from }+3 \text { (maximum positive tendency) to }-3 \\
\text { (maximum negative tendency). } 0 \text { indicates a stable tendency and may be } \\
\text { due to equal values for the variables or to addition of positive and } \\
\text { negative values of the variables. }\end{array}$ \\
\hline References & 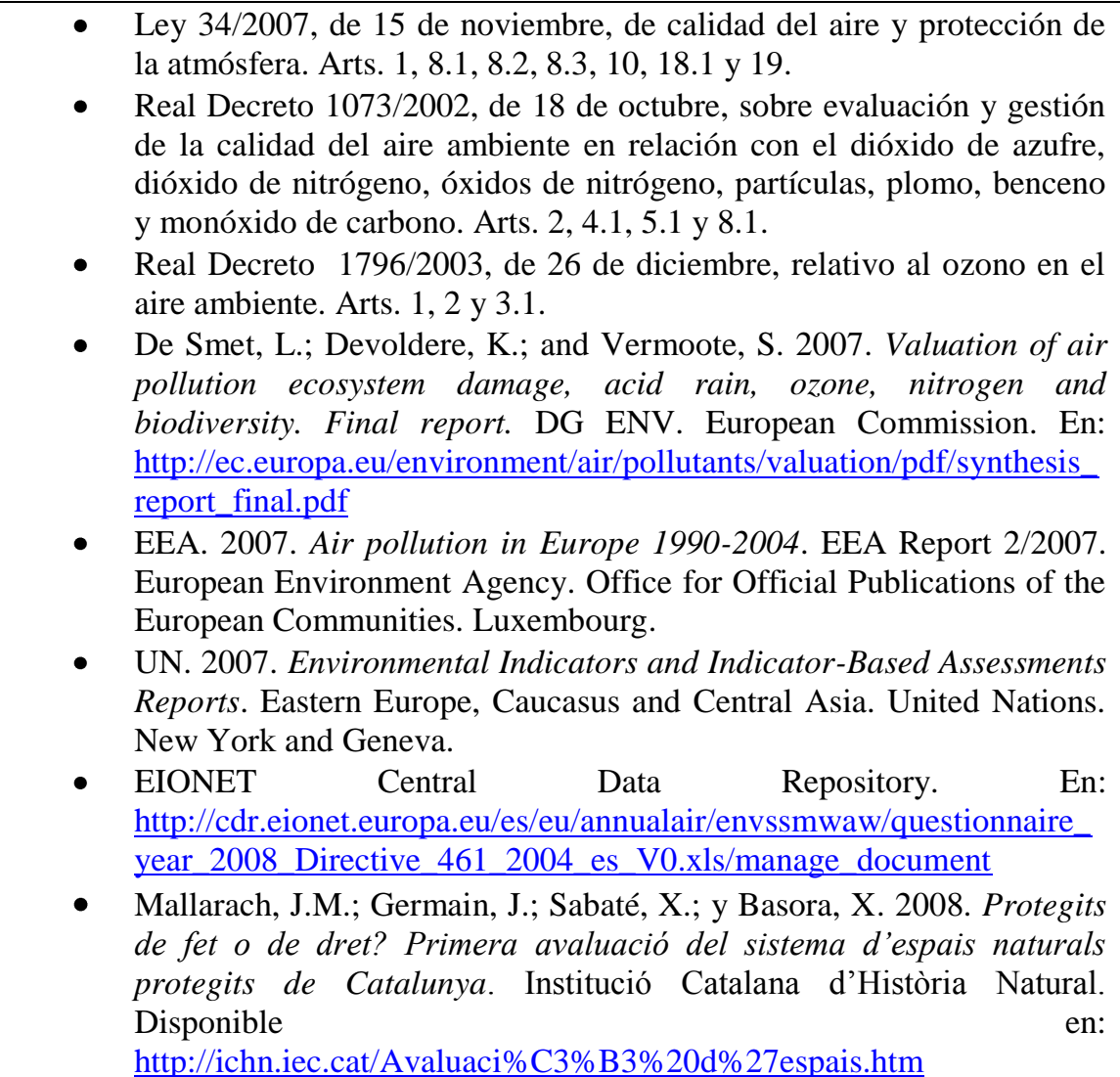 \\
\hline
\end{tabular}

\begin{tabular}{|c|c|}
\hline \multicolumn{2}{|c|}{ 1.5. Presence of solid waste } \\
\hline Category & State of conservation \\
\hline Type & Pressure \\
\hline Description & $\begin{array}{l}\text { This indicator assesses the presence of conspicuous and toxic solid waste } \\
\text { as well as rubbish dumps in protected areas }\end{array}$ \\
\hline Rationale & $\begin{array}{l}\text { The presence of scatered or concentrated solid waste has a notable } \\
\text { impact on the landscape quality of a protected area. Moreover, solid } \\
\text { waste may become a relevant source of pollution for living organisms, } \\
\text { depending on their characteristics and the environment where they are } \\
\text { disposed (Buckley et al., 2003; Brown et al., 2010) }\end{array}$ \\
\hline Data source & Censuses; CORINE Land-Cover \\
\hline \multicolumn{2}{|l|}{ Data availability } \\
\hline Updating & Annually \\
\hline Scale & Ordinal scale, from 0 to 2 \\
\hline $\begin{array}{l}\text { Calculation and } \\
\text { interpretation }\end{array}$ & $\begin{array}{l}\text { A census will be conducted of dispersed solid waste on the main } \\
\text { 'vulnerable zones' of the protected area (picnic areas). All the picnic } \\
\text { areas of the protected area will be visited early in the morning, from }\end{array}$ \\
\hline
\end{tabular}




\begin{tabular}{|c|c|}
\hline & 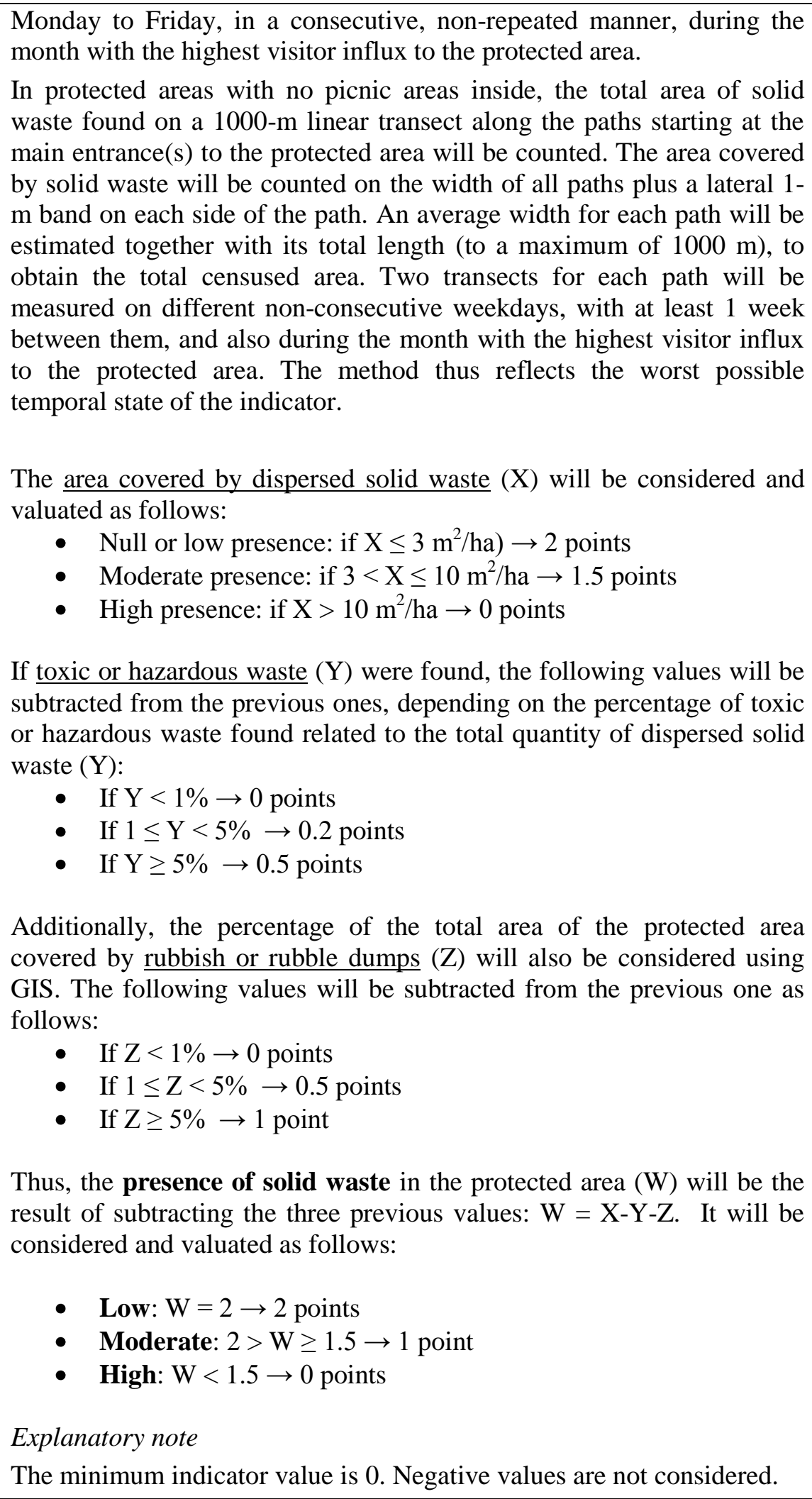 \\
\hline Tendency & $\begin{array}{l}\text { The tendency will be measured by comparing the scores for the three } \\
\text { variables between the last year analysed and the previous available data. } \\
\text { If the score of each of the three variables for the last year analysed is } \\
\text { larger than their scores for the year of comparison, } 1 \text { point will be } \\
\text { subtracted; if their scores are smaller that those of the year of } \\
\text { comparison, } 1 \text { point will be added; if their scores are the same for the } \\
\text { two years, } 0 \text { points will be added. Thus, the tendency between the two }\end{array}$ \\
\hline
\end{tabular}




\begin{tabular}{|l|l|}
\hline & $\begin{array}{l}\text { years analysed will be obtained by simple addition of the scores for the } \\
\text { three variables, with possible values ranging from }+3 \text { (maximum } \\
\text { positive tendency) to }-3 \text { (maximum negative tendency). 0 indicates a } \\
\text { stable tendency and may be due to equal scores for the variables or to the } \\
\text { addition of positive and negative values for the variables. }\end{array}$ \\
\hline References & Ley 10/1998, de 21 de abril, de Residuos. Arts. 2, 3, 4.2, 34.2.a.b.c, \\
& 34.3.a.b. \\
Real Decreto 952/1997, de 20 de junio, por el que se modifica el \\
Reglamento para la ejecución de la Ley 20/1986, de 14 de mayo, \\
básica de residuos tóxicos y peligrosos, aprobado mediante Real \\
Decreto 833/1988, de 20 de julio. Anexo 2. \\
Gómez-Limón, J.; Múgica, M.; Medina, L.; y De Lucio, J.V. 1994. \\
Áreas recreativas en la Comunidad de Madrid. Afluencia de visitantes \\
y actividades desarrolladas. Serie Documentos, no 14. Centro de \\
Investigación "Fernando González Bernáldez". Soto del Real, Madrid. \\
Buckley, R.; Weaver, D.B.; and Pickering, C. (Eds). 2003. Nature- \\
based tourism, environment and land management. Oxfordshire, UK, \\
and Cambridge, USA. CABI Publishing. \\
Brown, T.J.; Ham, S.H.; and Hughes, M. 2010. Picking up litter: an \\
application of theory-based communication to influence tourist \\
behaviour in protected areas. Journal of Sustainable Tourism 18 (7): \\
879-900. \\
Rodríguez-Rodríguez, D. In press. Littering in protected areas: a \\
conservation and Management challenge. A case study from the \\
Autonomous Region of Madrid. Journal of Sustainable Tourism. DOI: \\
10.1080/09669582.2011.651221
\end{tabular}

\begin{tabular}{|c|c|}
\hline \multicolumn{2}{|c|}{ 1.6. Landscape impact } \\
\hline Category & State of conservation \\
\hline Type & State \\
\hline Description & $\begin{array}{l}\text { This indicator assesses the impacts on the landscape in protected areas in } \\
\text { an aggregated manner }\end{array}$ \\
\hline Rationale & $\begin{array}{l}\text { Despite the relevance of landscapes as aesthetic, cultural, ecological and } \\
\text { recreational resources, they are not usually considered in assessments of } \\
\text { protected areas or on the status of the environment or sustainability. } \\
\text { Human activities, such as the growth of urban areas, the building of } \\
\text { infrastructure or the installation of waste dumps, change the } \\
\text { characteristics of the landscapes (Aramburu et al., 2003). } \\
\text { In order to compare the visual quality of a landscape independently of its } \\
\text { intrinsic quality, only the quantity and severity of the impacts on the } \\
\text { landscapes in each protected area were considered. Therefore, the best- } \\
\text { conserved landscape is that with the fewest impacts on its visual quality }\end{array}$ \\
\hline \multicolumn{2}{|l|}{ Data source } \\
\hline \multicolumn{2}{|l|}{ Data availability } \\
\hline Updating & Every 4 years \\
\hline Scale & Ordinal scale, from 0 to 2 \\
\hline $\begin{array}{l}\text { Calculation and } \\
\text { interpretation }\end{array}$ & $\begin{array}{l}\text { The viewsheds of the main elements that have negative impacts on } \\
\text { landscapes in the territory comprising each protected area will be } \\
\text { calculated using GIS. } \\
\text { Landscape impact scores will be obtained by simple addition of the }\end{array}$ \\
\hline
\end{tabular}




\begin{tabular}{|c|c|}
\hline & $\begin{array}{l}\text { scores for each raster output layer, each pixel scoring } 0 \text { (not visible) or } 1 \\
\text { (visible). Then, the average landscape impact score will be calculated for } \\
\text { each protected area }(\mathrm{X}) \text { by weighting each impacting element as follows: } \\
\text {-Highway network (x3) } \\
\text {-Main road network (x2) } \\
\text {-Secondary road network (x1) } \\
\text {-Local road network (x1) } \\
\text {-Railway network (x1) } \\
\text {-Rubbish and rubble dumps (x3) } \\
\text {-Urban areas (x2) } \\
\text { The landscape impact in the protected area (X) will be considered and } \\
\text { valuated as follows: } \\
\text { - Low: if } 0 \leq \mathrm{X} \leq 4 \rightarrow 2 \text { points } \\
\text { - Moderate: if } 4<\mathrm{X} \leq 7 \rightarrow 1 \text { point } \\
\text { - High: if } \mathrm{X}>7 \rightarrow 0 \text { points }\end{array}$ \\
\hline Tendency & $\begin{array}{l}\text { The tendency will be considered positive if } \mathrm{X} \text { is larger than in the } \\
\text { preceding assessment, stable if it is the same, or negative if it is smaller }\end{array}$ \\
\hline References & $\begin{array}{l}\text { - Ley } 42 / 2007 \text {, de } 13 \text { de diciembre, del Patrimonio Natural y de la } \\
\text { Biodiversidad. Arts. 2, 3.26, 19.b, 30.1, } 34 \text { y } 46 . \\
\text { - Ley } 16 / 1995, \text { de } 4 \text { de mayo, Forestal y de Protección de la Naturaleza. } \\
\text { Art. 2.1.c. } \\
\text { - Aramburu, M. P.; Escribano, R.; Ramos, L.; y Rubio, R. } 2003 . \\
\text { Cartografía del Paisaje de la Comunidad de Madrid. Consejería de } \\
\text { Medio Ambiente. Comunidad de Madrid. Madrid. }\end{array}$ \\
\hline
\end{tabular}

\section{Planning: seven indicators}

\begin{tabular}{|l|l|}
\hline 2.1. Appropriateness of protection legislation \\
\hline Category & Planning \\
\hline Type & Response \\
\hline Description & $\begin{array}{l}\text { This indicator assesses the adequacy of the protection legislation } \\
\text { affecting the protected area and, particularly, the designation norm and } \\
\text { the protection category }\end{array}$ \\
\hline Rationale & $\begin{array}{l}\text { Most protected areas are established though legal processes (Chape } \text { et } \\
\text { al., 2008). The existence of an adequate legal framework is considered } \\
\text { the first step in efficient management of a protected area (Pomeroy et al., } \\
\text { 2005). It is also one of the minimum standard requirements for } \\
\text { individual protected areas (Carabias } \text { et al., 2004) }\end{array}$ \\
\hline Data source & \multicolumn{2}{|l|}{} \\
\hline Data availability & Every 4 years \\
\hline Updating & Ordinal scale, from 0 to 2 \\
\hline Scale & $\begin{array}{l}\text { The following issues in the legal regime governing the protected area } \\
\text { will be valuated: }\end{array}$ \\
\hline $\begin{array}{l}\text { Calculation and } \\
\text { interpretation }\end{array}$
\end{tabular}




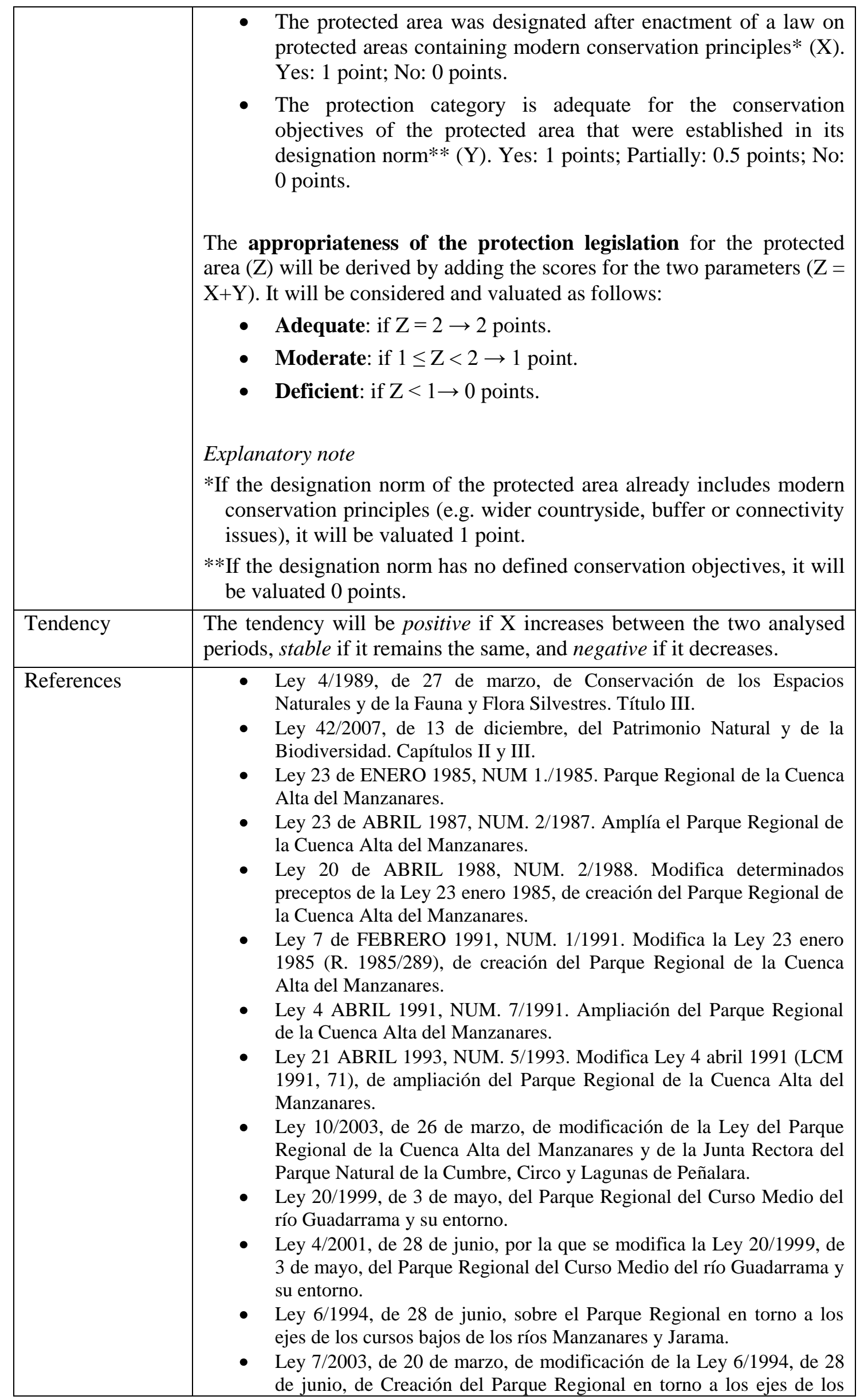




\begin{tabular}{|c|c|}
\hline & 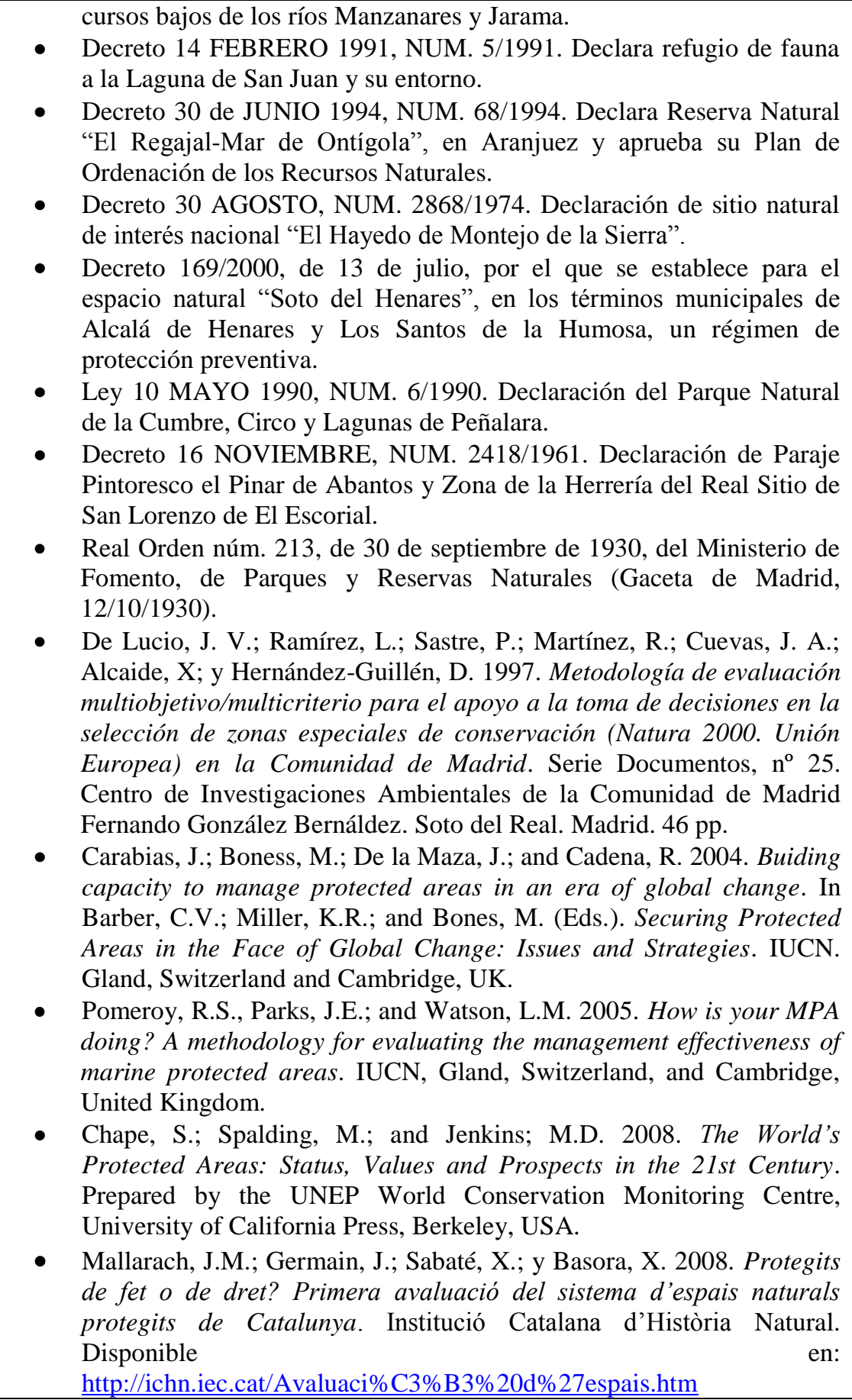 \\
\hline
\end{tabular}

\subsection{Existence of updated planning documents}

\begin{tabular}{|l|l|}
\hline Category & Planning \\
\hline Type & Response \\
\hline Description & $\begin{array}{l}\text { This indicator assesses the existence of updated planning documents } \\
\text { describing the natural resources of the protected area and regulating their } \\
\text { use }\end{array}$ \\
\hline Rationale & $\begin{array}{l}\text { No organization can achieve its management objectives without } \\
\text { appropriate planning at different levels (Chape et al., 2008). Documents }\end{array}$ \\
\hline
\end{tabular}




\begin{tabular}{|c|c|}
\hline & $\begin{array}{l}\text { addressing the planning of natural resources are fundamental normative } \\
\text { tools for adequate planning of protected areas and their surrounding } \\
\text { territories (Múgica et al., 2010) }\end{array}$ \\
\hline \multicolumn{2}{|l|}{ Data source } \\
\hline \multicolumn{2}{|l|}{ Data availability } \\
\hline Updating & Every 2 years \\
\hline Scale & Ordinal scale, from 0 to 2 \\
\hline $\begin{array}{l}\text { Calculation and } \\
\text { interpretation }\end{array}$ & $\begin{array}{l}\text { The existence of updated planning documents will be considered and } \\
\text { valuated as follows: } \\
\text { - Adequate: if there are updated* natural resources planning } \\
\text { documents in force for the protected area } \rightarrow 2 \text { points. } \\
\text { - Moderate: if there are natural resources planning documents for } \\
\text { the protected area, but they are not updated or not in force } \rightarrow 1 \\
\text { point. } \\
\text { - Deficient: if there are no natural resources planning documents } \\
\text { for the protected area } \rightarrow 0 \text { points. } \\
\text { Explanatory notes } \\
\text { *A document is considered "not updated" when it is older than its } \\
\text { stipulated enforcement period or, if that period is not specified, the } \\
\text { document or plan is over } 10 \text { years old. }\end{array}$ \\
\hline Tendency & $\begin{array}{l}\text { The tendency will be positive if the value of the indicator is higher than } \\
\text { in the previous assessment, stable if the value is the same in the two } \\
\text { assessments, and negative if the most recent value is lower than the } \\
\text { previous one }\end{array}$ \\
\hline References & 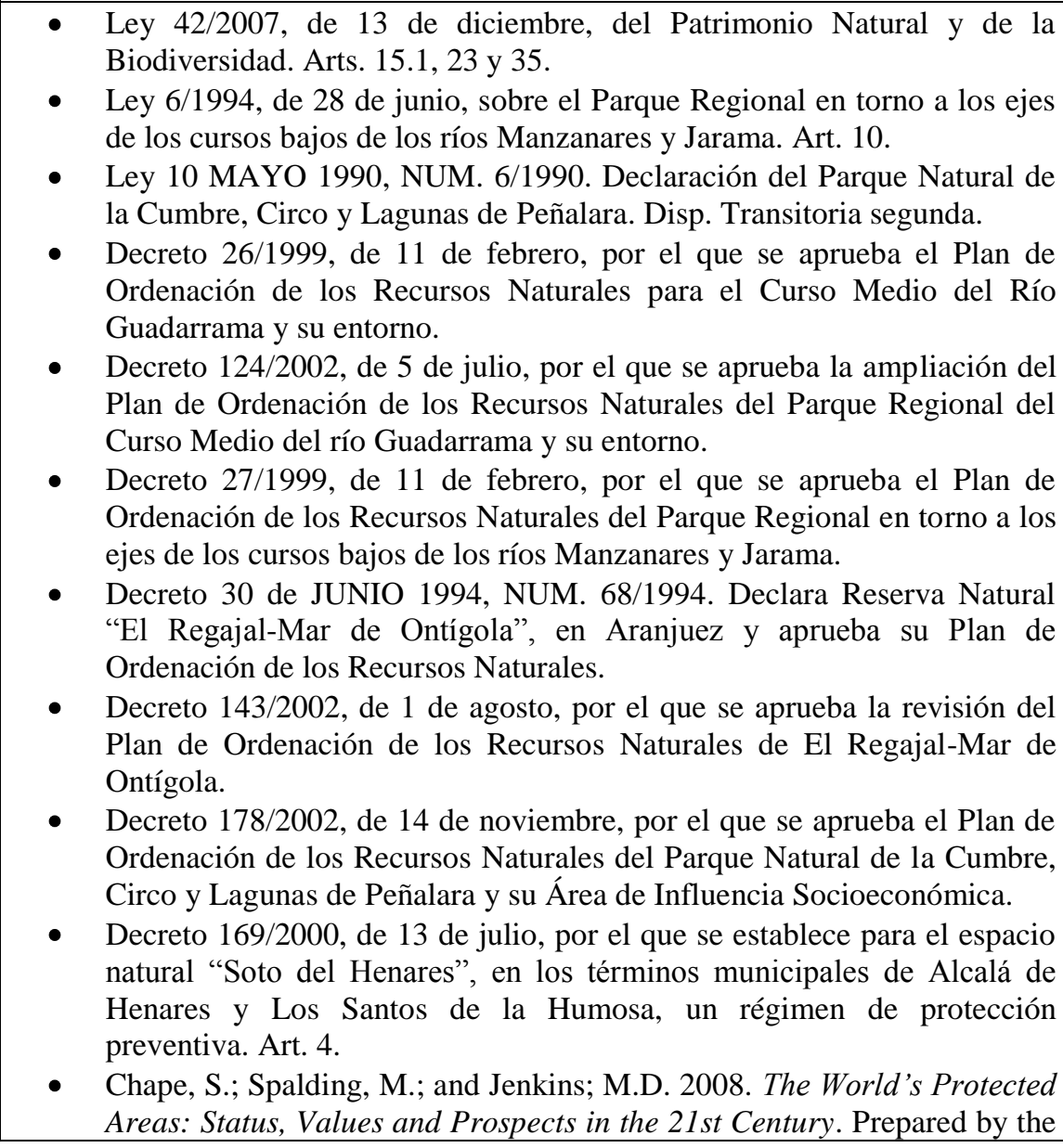 \\
\hline
\end{tabular}




\begin{tabular}{|l|l|}
\hline & UNEP World Conservation Monitoring Centre, University of California \\
& Press, Berkeley, USA. \\
& Mallarach, J.M.; Germain, J.; Sabaté, X.; y Basora, X. 2008. Protegits de \\
& fet o de dret? Primera avaluació del sistema d'espais naturals protegits \\
de Catalunya. Institució Catalana d'Història Natural. Disponible en: \\
http://ichn.iec.cat/Avaluaci\%C3\%B3\%20d\%27espais.htm \\
Múgica, M.; Martínez-Alandi, C.; Gómez-Limón, J.; Puertas, J.; Atauri, \\
J.A.; y De Lucio, J.V.. 2010. Anuario EUROPARC-España del estado de \\
los espacios naturales protegidos 2009. Fundación Fernando González \\
Bernáldez. Madrid.
\end{tabular}

\begin{tabular}{|c|c|}
\hline \multicolumn{2}{|c|}{ 2.3. Existence of updated documents on social and economic development } \\
\hline Category & Planning \\
\hline Type & Response \\
\hline Description & $\begin{array}{l}\text { This indicator assesses the existence of updated documents on the social } \\
\text { and economic aspects of the protected area, such as a socioeconomic or } \\
\text { sustainable development plan }\end{array}$ \\
\hline Rationale & $\begin{array}{l}\text { The social and economic plans are normative documents derived by } \\
\text { participative approaches, which seek to improve the quality of life of } \\
\text { residents inside protected areas or in their influence areas by promoting } \\
\text { valorization of the protected area and the goods and services it provides } \\
\text { to stimulate economic growth and human well-being (Pinilla, 2007) }\end{array}$ \\
\hline \multicolumn{2}{|l|}{ Data source } \\
\hline \multicolumn{2}{|l|}{ Data availability } \\
\hline Updating & Every 4 years \\
\hline Scale & Ordinal scale, from 0 to 2 \\
\hline $\begin{array}{l}\text { Calculation and } \\
\text { interpretation }\end{array}$ & $\begin{array}{l}\text { The existence of updated documents on social and economic } \\
\text { development will be considered and valuated as follows: } \\
\text { - Adequate: if there are updated* socioeconomic planning } \\
\text { documents in force on the protected area } \rightarrow 2 \text { points. } \\
\text { - Moderate: if there are socioeconomic planning documents on } \\
\text { the protected area, but they are not updated or not in force } \rightarrow 1 \\
\text { point. } \\
\text { - Deficient: if there are not socioeconomic planning documents } \\
\text { on the protected area } \rightarrow 0 \text { points. } \\
\text { Explanatory note } \\
\text { *A document is considered "not updated" when it is older than its } \\
\text { stipulated enforcement period or, if that period is not specified, the } \\
\text { document or plan is over } 10 \text { years old. } \\
\text { If the plan is included as detailed specifications in another plan, such as } \\
\text { a natural resources or management plan, it will be valuated as if it were } \\
\text { an independent plan. }\end{array}$ \\
\hline Tendency & $\begin{array}{l}\text { The tendency will be positive if the value of the indicator is higher than } \\
\text { in the previous assessment, stable if the value is the same in the two } \\
\text { assessments, and negative if the most recent value is lower than the } \\
\text { previous one }\end{array}$ \\
\hline References & $\begin{array}{l}\text { - Ley 42/2007, de } 13 \text { de diciembre, del Patrimonio Natural y de la } \\
\text { Biodiversidad. Arts. } 2,15 \text { y } 38 .\end{array}$ \\
\hline
\end{tabular}




\begin{tabular}{|l|l|}
\hline & $\bullet \begin{array}{l}\text { Pinilla, R. (Coord.). 2007. Plan de Desarrollo Sostenible. Parque } \\
\text { Natural Sierra de Huétor. Consejería de Medio Ambiente. Junta de } \\
\text { Andalucía. }\end{array}$ \\
\hline
\end{tabular}

\begin{tabular}{|c|c|}
\hline \multicolumn{2}{|c|}{ 2.4. Existence of updated management documents } \\
\hline Category & Planning \\
\hline Type & Response \\
\hline Description & $\begin{array}{l}\text { This indicator assesses the existence of updated documents on the } \\
\text { management of the protected area, such as a management plan. }\end{array}$ \\
\hline Rationale & $\begin{array}{l}\text { Updated, adaptable, information-based management documents are a } \\
\text { fundamental requirement for active, effective management of protected } \\
\text { areas in the context of global change (Múgica and Gómez-Limón, 2002; } \\
\text { Pullin, 2002; de Lucio and Múgica, 2004; Pomeroy et al., 2005; Chape } \\
\text { et al., 2008). The existence of a published, complete, legally approved } \\
\text { management plan is one of the minimum international standards for } \\
\text { individual protected areas (Carabias et al., 2004) }\end{array}$ \\
\hline \multicolumn{2}{|l|}{ Data source } \\
\hline \multicolumn{2}{|l|}{ Data availability } \\
\hline Updating & Every 4 years \\
\hline Scale & Ordinal scale, from 0 to 2 \\
\hline $\begin{array}{l}\text { Calculation and } \\
\text { interpretation }\end{array}$ & $\begin{array}{l}\text { The existence of updated management documents will be considered } \\
\text { and valuated as follows: } \\
\text { - Adequate: if there is an updated* management document in } \\
\text { force on the protected area } \rightarrow 2 \text { points. } \\
\text { - Moderate: if there is a management document on the protected } \\
\text { area, which is not updated or not in force } \rightarrow 1 \text { point. } \\
\text { - Deficient: if there is no management document on the protected } \\
\text { area } \rightarrow 0 \text { points. } \\
\text { Explanatory note } \\
\text { *A document is considered "not updated" when it is older than its } \\
\text { stipulated enforcement period or, if that period is not specified, the } \\
\text { document or plan is over } 10 \text { years old. } \\
\text { If detailed management criteria are specified in other types of planning } \\
\text { documents, these will be considered independent management plans, } \\
\text { except for parks, which must have an independent management plan. }\end{array}$ \\
\hline Tendency & $\begin{array}{l}\text { The tendency will be positive if the value of the indicator is higher than } \\
\text { in the previous assessment, stable if the value is the same in the two } \\
\text { assessments, and negative if the most recent value is lower than the } \\
\text { previous one. }\end{array}$ \\
\hline References & $\begin{array}{l}\text { - Ley 42/2007, de } 13 \text { de diciembre, del Patrimonio Natural y de la } \\
\text { Biodiversidad. Arts.15, 28.1,30.5 y 45.a. } \\
\text { - Ley 23 ENERO 1985, NUM. 1/1985. Parque Regional de la Cuenca } \\
\text { Alta del Manzanares. Art. } 11 \text {. } \\
\text { • Ley 20/1999, de } 3 \text { de mayo, del Parque Regional del Curso Medio del } \\
\text { río Guadarrama y su entorno. Art. } 12 \text {. } \\
\text { - Ley 6/1994, de } 28 \text { de junio, sobre el Parque Regional en torno a los } \\
\text { ejes de los cursos bajos de los ríos Manzanares y Jarama. Arts. } 16 \text { y } 18 . \\
\text { - Ley } 10 \text { MAYO 1990, NUM. 6/1990. Declaración del Parque Natural }\end{array}$ \\
\hline
\end{tabular}




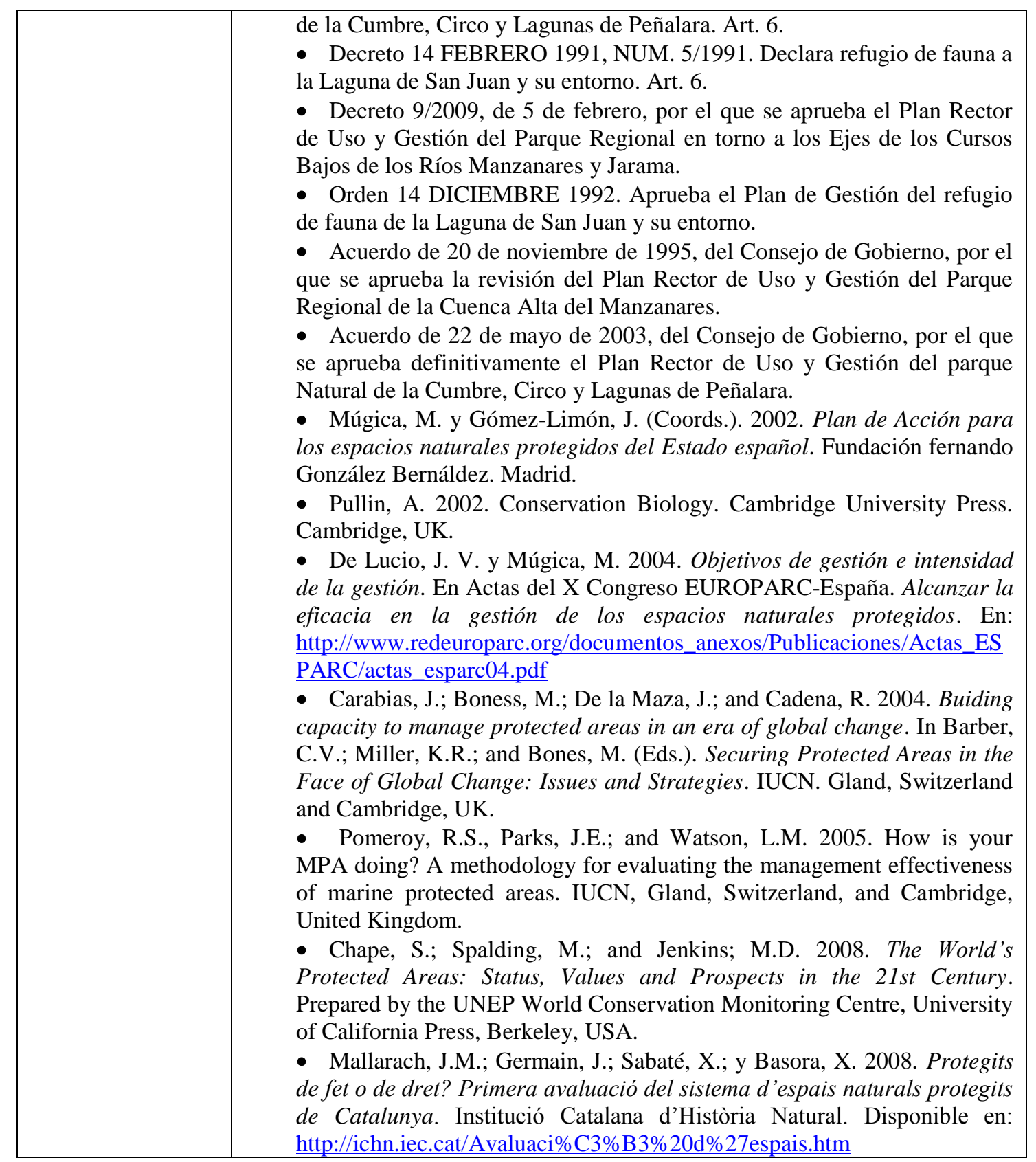

\begin{tabular}{|l|l|}
\hline 2.5. Existence of updated documents on public use \\
\hline Category & Planning \\
\hline Type & Response \\
\hline Description & $\begin{array}{l}\text { This indicator assesses the existence of updated documents regulating } \\
\text { public use of the protected area, such as plans, programmes or guidelines }\end{array}$ \\
\hline Rationale & $\begin{array}{l}\text { Recreation activities are currently the main threat to the conservation of } \\
\text { European protected areas (Nolte } \text { et al., 2010) and of the protected areas } \\
\text { of the Autonomous Region of Madrid (Rodríguez-Rodríguez, 2008). } \\
\text { Such activities are especially serious for protected areas located in } \\
\text { densely populated areas. Also, issues related to visitor safety and the } \\
\text { quality of visits make adequate regulation of such activities advisable } \\
\text { (Ortega et al., 2006). In brief, appropriate planning of public use is an }\end{array}$ \\
\hline
\end{tabular}




\begin{tabular}{|c|c|}
\hline & $\begin{array}{l}\text { essential tool for the sustainable management of a protected area (Chape } \\
\text { et al., 2008) }\end{array}$ \\
\hline \multicolumn{2}{|l|}{ Data source } \\
\hline \multicolumn{2}{|l|}{ Data availability } \\
\hline Updating & Every 4 years \\
\hline Scale & Ordinal scale, from 0 to 2 \\
\hline $\begin{array}{l}\text { Calculation and } \\
\text { interpretation }\end{array}$ & $\begin{array}{l}\text { The existence of updated documents on public use will be considered } \\
\text { and valuated as follows: } \\
\text { - Adequate: if there is an individual updated* plan, programme or } \\
\text { guidelines on public use in force } \rightarrow 2 \text { points } \\
\text { - Moderate: if there is an individual plan, programme or } \\
\text { guidelines on public use but it is not updated or in force or it is } \\
\text { integrated as general guidelines into articles or chapters in other } \\
\text { plans or programmes } \rightarrow 1 \text { point } \\
\text { - Deficient: if there is no individual plan, programme or } \\
\text { guidelines or general guidelines integrated into other plans or } \\
\text { programmes } \rightarrow 0 \text { points } \\
\text { Explanatory note } \\
\text { *A document is considered "not updated" when it is older than its } \\
\text { stipulated enforcement period or, if that period is not specified, the } \\
\text { document or plan is over } 5 \text { years old. }\end{array}$ \\
\hline Tendency & $\begin{array}{l}\text { The tendency will be positive if the value of the indicator is higher than } \\
\text { in the previous assessment, stable if it is the same in the two assessments } \\
\text { and negative if the most recent value is lower than the previous one }\end{array}$ \\
\hline References & $\begin{array}{l}\text { - Decreto 143/2002, de } 1 \text { de agosto, por el que se aprueba la revisión del } \\
\text { Plan de Ordenación de los Recursos Naturales de El Regajal-Mar de } \\
\text { Ontígola. } \\
\text { Decreto } 178 / 2002 \text {, de } 14 \text { de noviembre, por el que se aprueba el Plan de } \\
\text { Ordenación de los Recursos Naturales del Parque Natural de la Cumbre, } \\
\text { Circo y Lagunas de Peñalara y su Área de Influencia Socioeconómica. } \\
\text { Decreto } 26 / 1999 \text {, de } 11 \text { de febrero, por el que se aprueba el Plan de } \\
\text { Ordenación de los Recursos Naturales para el Curso Medio del Río } \\
\text { Guadarrama y su entorno. } \\
\text { Decreto 124/2002, de } 5 \text { de julio, por el que se aprueba la ampliación del } \\
\text { Plan de Ordenación de los Recursos Naturales del Parque Regional del } \\
\text { Curso Medio del río Guadarrama y su entorno. } \\
\text { - Decreto 27/1999, de } 11 \text { de febrero, por el que se aprueba el Plan de } \\
\text { Ordenación de los Recursos Naturales del Parque Regional en torno a los } \\
\text { ejes de los cursos bajos de los ríos Manzanares y Jarama. } \\
\text { Acuerdo de } 22 \text { de mayo de } 2003 \text {, del Consejo de Gobierno, por el que se } \\
\text { aprueba definitivamente el Plan Rector de Uso y Gestión del parque } \\
\text { Natural de la Cumbre, Circo y Lagunas de Peñalara. } \\
\text { Decreto } 14 \text { FEBRERO } 1991 \text {, NUM. 5/1991. Declara refugio de fauna a } \\
\text { la Laguna de San Juan y su entorno. } \\
\text { Decreto 9/2009, de } 5 \text { de febrero, por el que se aprueba el Plan Rector de } \\
\text { Uso y Gestión del Parque Regional en torno a los Ejes de los Cursos } \\
\text { Bajos de los Ríos Manzanares y Jarama. } \\
\text { Orden } 14 \text { DICIEMBRE } 1992 \text {. Aprueba el Plan de Gestión del refugio de } \\
\text { fauna de la Laguna de San Juan y su entorno. } \\
\text { Acuerdo de } 20 \text { de noviembre de } 1995 \text {, del Consejo de Gobierno, por el } \\
\text { que se aprueba la revisión del Plan Rector de Uso y Gestión del Parque } \\
\text { Regional de la Cuenca Alta del Manzanares. } \\
\text { Barrado, D. } 1999 \text {. Actividades de ocio y recreativas en el medio natural } \\
\text { de la Comunidad de Madrid. La ciudad a la búsqueda de la naturaleza. }\end{array}$ \\
\hline
\end{tabular}




\begin{tabular}{|l|l|}
\hline & Consejería de Medio Ambiente. Comunidad de Madrid. \\
& Ortega, J.; Gómez-Limón, J.; Rovira, P.; López-Claramunt, A.; y \\
& Gabaldón, J. E. 2006. Evaluación del papel que cumplen los \\
& equipamientos de uso público en los ENPs. Fundación Fernando \\
& González Bernáldez. Madrid. \\
& Chape, S.; Spalding, M.; and Jenkins; M.D. 2008. The World's Protected \\
& Areas: Status, Values and Prospects in the 21st Century. Prepared by the \\
& UNEP World Conservation Monitoring Centre, University of California \\
& Press, Berkeley, USA. \\
& Rodríguez-Rodríguez, D. 2008. Los espacios naturales protegidos de la \\
& Comunidad de Madrid. Principales amenazas para su conservación. \\
& Editorial Complutense. \\
& http://www.ucm.es/BUCM/ecsa/36254.php?id=187 \\
Nolte, C.; Leverington, F.; Kettner, A.; Marr, M.; Nielsen, G.; Bomhard, \\
B.; Stolton, S.; Stoll-Kleemann, S.; and Hockings, M. 2010. Protected \\
Area Management Effectiveness Assessments in Europe. A review of \\
application, methods and results. University of Greifswald. Greifswald, \\
Germany.
\end{tabular}

\begin{tabular}{|c|c|}
\hline \multicolumn{2}{|l|}{ 2.6. Zoning } \\
\hline Category & Planning \\
\hline Type & Response \\
\hline Description & $\begin{array}{l}\text { This indicator assesses the division of the protected area into } \\
\text { management zones with different administrative characteristics and } \\
\text { protection levels. }\end{array}$ \\
\hline Rationale & $\begin{array}{l}\text { The division of large or complex protected areas into different zones } \\
\text { with different degrees of regulation of activities allows more efficient } \\
\text { management of the whole protected area by adapting management to the } \\
\text { specific characteristics and needs of each zone. In any type of protected } \\
\text { area, it is assumed that the existence of a buffer zone mitigates outer } \\
\text { impacts on the core zone, which is the most fragile and valuable for } \\
\text { conservation (Spellerberg, 1994; Pressey et al., 2007). Zoning is one of } \\
\text { the minimum international standards for individual protected areas } \\
\text { (Carabias et al., 2004) }\end{array}$ \\
\hline \multicolumn{2}{|l|}{ Data source } \\
\hline \multicolumn{2}{|l|}{ Data availability } \\
\hline Updating & Every 5 years \\
\hline Scale & Ordinal scale, from 0 to 2 \\
\hline $\begin{array}{l}\text { Calculation and } \\
\text { interpretation }\end{array}$ & $\begin{array}{l}\text { The zoning of the protected area will be considered and valuated as } \\
\text { follows: } \\
\text { - Adequate: if there are three legally established zones in the } \\
\text { protected area: a core zone (which may be subdivided into } \\
\text { different protection zones), a buffer zone and a zone of social } \\
\text { and economic influence (which may be the same as the previous } \\
\text { zone) } \rightarrow 2 \text { points. } \\
\text { - Moderate*: if the protected area has at least two legally } \\
\text { established zones: a core zone (which may be subdivided into } \\
\text { different protection zones) and a buffer zone } \rightarrow 1 \text { point. } \\
\text { - Deficient: if the whole protected area corresponds to a single }\end{array}$ \\
\hline
\end{tabular}




\begin{tabular}{|c|c|}
\hline & $\begin{array}{l}\text { zone } \rightarrow 0 \text { points. } \\
\text { Explanatory note } \\
\text { *Protected areas with different legally established protection zones will } \\
\text { be considered 'moderate' even though they do not have a buffer zone. } \\
\text { They will be valuated } 1 \text { point. }\end{array}$ \\
\hline Tendency & $\begin{array}{l}\text { The tendency will be positive if the protected area has diversified its } \\
\text { zoning since the last assessment, stable if its zoning remains the same, } \\
\text { and negative if the number of management zones has decreased between } \\
\text { the two assessment dates. }\end{array}$ \\
\hline References & 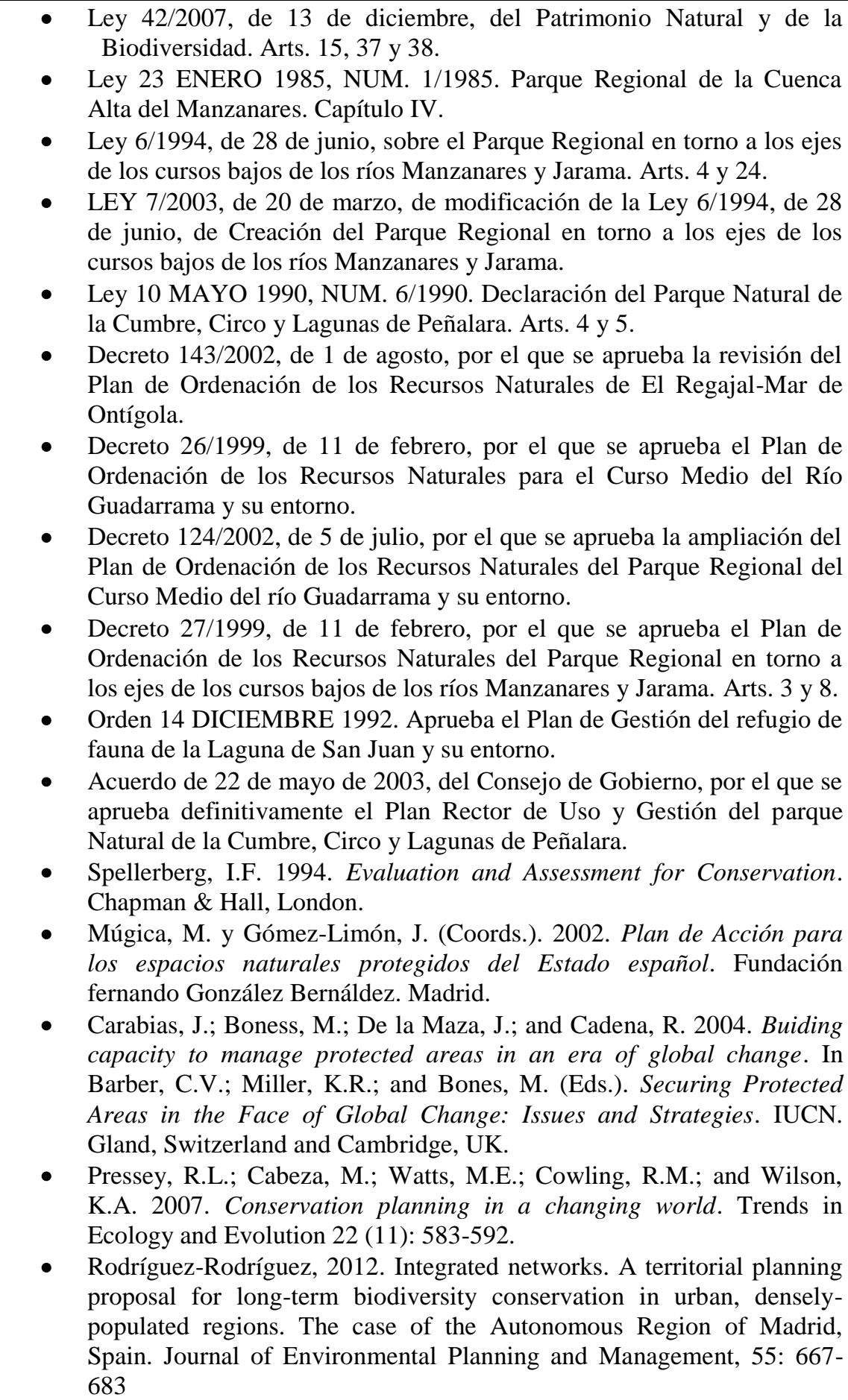 \\
\hline
\end{tabular}




\begin{tabular}{|c|c|}
\hline \multicolumn{2}{|c|}{ 2.7. Evolution of the area designated as protected } \\
\hline Category & Planning \\
\hline Type & Response \\
\hline Description & $\begin{array}{l}\text { This indicator assesses the evolution of the area of the protected area } \\
\text { which is legally designated as protected }\end{array}$ \\
\hline Rationale & $\begin{array}{l}\text { The importance of size for the efficiency of conservation of protected } \\
\text { areas (Pullin, 2002) and speculative pressures on land inside and in the } \\
\text { surroundings of protected areas (Radeloff et al., 2010) make it necessary } \\
\text { to analyse the evolution of the area of the protected areas legally } \\
\text { designated as protected }\end{array}$ \\
\hline \multicolumn{2}{|l|}{ Data source } \\
\hline \multicolumn{2}{|l|}{ Data availability } \\
\hline Updating & Every five years \\
\hline Scale & Ordinal scale, from 0 to 2 \\
\hline $\begin{array}{l}\text { Calculation and } \\
\text { interpretation }\end{array}$ & $\begin{array}{l}\text { The evolution of the area designated as protected will be considered } \\
\text { and valuated as follows: } \\
\text { - Adequate: There has been an augmentation of the legally } \\
\text { designated area of the protected area (including its buffer zone } \\
\text { or zone of social and economic influence, whether they exist) } \\
\text { since it was declared } \rightarrow 2 \text { points } \\
\text { - Neutral: The legally designated area has remained equal since } \\
\text { its designation } \rightarrow 1 \text { point } \\
\text { - Deficient: There has been a reduction in the legally designated } \\
\text { area of the protected area (including its buffer zone or zone of } \\
\text { social and economic influence, whether they exist) since it was } \\
\text { declared } \rightarrow 0 \text { points } \\
\text { Explanatory note } \\
\text { The loss of net area by the protected area resulting from works or } \\
\text { projects will not be considered, as long as it does not imply a legal re- } \\
\text { classification of that area. } \\
\text { If there has been a simultaneous increase and decrease in the legally } \\
\text { designated area between the assessment date and the designation date of } \\
\text { the protected area, the total added (or substracted) area will be calculated } \\
\text { to value the indicator (adequate evolution, if the addition is higher than } \\
\text { the substraction, or deficient evolution, if the substraction is higher than } \\
\text { the addition) }\end{array}$ \\
\hline Tendency & $\begin{array}{l}\text { The tendency will be positive if the legally designated area has increased } \\
\text { between the last date assessed and the previous assessment, stable if the } \\
\text { area is equal for the last two assessments, and negative if the legally } \\
\text { designated area has decreased between the last assessed date and the } \\
\text { previous one }\end{array}$ \\
\hline References & $\begin{array}{l}\text { - LEY 7/2003, de } 20 \text { de marzo, de modificación de la Ley 6/1994, de } 28 \\
\text { de junio, de Creación del Parque Regional en torno a los ejes de los } \\
\text { cursos bajos de los ríos Manzanares y Jarama. } \\
\text { - LEY } 23 \text { ABRIL 1987, NUM. 2/1987. Amplía el Parque Regionalde la } \\
\text { Cuenca Alta del Manzanares. } \\
\text { - LEY } 7 \text { FEBRERO 1991, NUM. 1/1991. Modifica la Ley de } 23 \text { de enero } \\
\text { 1985 (R. 1985/289), de creación del Parque Regional de la Cuenca } \\
\text { Alta del Manzanares. } \\
\text { - LEY } 4 \text { ABRIL 1991, NUM. 7/1991. PARQUES Y RESERVAS } \\
\text { NATURALES. Ampliación del Parque Regional de la Cuenca Alta del } \\
\text { Manzanares. }\end{array}$ \\
\hline
\end{tabular}




\begin{tabular}{|l|l|}
\hline LEY 21 ABRIL 1993, NUM. 5/1993. PARQUES Y RESERVAS \\
NATURALES. Modifica la Ley 4 abril 1991 (LCM 1991, 71), de \\
ampliación del Parque Regional de la Cuenca Alta del Manzanares. \\
LEY 10/2003, de 26 de marzo, de modificación de la Ley del Parque \\
Regional de la Cuenca Alta del Manzanares y de la Junta Rectora del \\
Parque Natural de la Cumbre, Circo y Lagunas de Peñalara. \\
Decreto 143/2002, de 1 de agosto, por el que se aprueba la revisión del \\
Plan de Ordenación de los Recursos Naturales de El Regajal-Mar de \\
Ontígola. \\
Decreto 124/2002, de 5 de julio, por el que se aprueba la ampliación del \\
Plan de Ordenación de los Recursos Naturales del Parque Regional del \\
Curso Medio del río Guadarrama y su entorno. \\
Acuerdo de 22 de mayo de 2003, del Consejo de Gobierno, por el que se \\
aprueba definitivamente el Plan Rector de Uso y Gestión del parque \\
Natural de la Cumbre, Circo y Lagunas de Peñalara. \\
Pullin, A.S. 2002. Conservation Biology. Cambridge University Press. \\
Cambridge, UK. \\
Mallarach, J.M.; Germain, J.; Sabaté, X.; y Basora, X. 2008. Protegits de \\
fet o de dret? Primera avaluació del sistema d'espais naturals protegits \\
de Catalunya. Institució Catalana d'Història Natural. Disponible en: \\
http://ichn.iec.cat/Avaluaci\%C3\%B3\%20d\%27espais.htm \\
Radeloff, V.C.; Stewart, S.I.; Hawbaker, T.J.; Gimmi, U.; Pidgeon, \\
A.M.; Flather, C.H.; Hammer, R.B.; and Helmers, D.P. 2010. Housing \\
growth in and near United States protected areas limits their \\
conservation value. PNAS 107 (2): 940-945.
\end{tabular}

\section{Management: twelve indicators}

\begin{tabular}{|c|c|}
\hline \multicolumn{2}{|c|}{ 3.1. Degree of characterization of the protected area } \\
\hline Category & Management \\
\hline Type & State \\
\hline Description & $\begin{array}{l}\text { This indicator assesses the degree of knowledge about the biotic, abiotic } \\
\text { and social feautures of the protected area }\end{array}$ \\
\hline Rationale & $\begin{array}{l}\text { One of the first and main duties of a protected area manager should be } \\
\text { the complete and updated characterization of its natural resources. The } \\
\text { lack of knowledge on natural resources implies serious limitations for } \\
\text { management and important risks for their effective conservation (Chape } \\
\text { et al., 2008) }\end{array}$ \\
\hline \multicolumn{2}{|l|}{ Data source } \\
\hline \multicolumn{2}{|l|}{ Data availability } \\
\hline Updating & Every five years \\
\hline Scale & Ordinal scale, from 0 to 2 \\
\hline $\begin{array}{l}\text { Calculation and } \\
\text { interpretation }\end{array}$ & $\begin{array}{l}\text { The characterization of the different features of the protected area will be } \\
\text { valuated as follows: } \\
\text { - Characterization of abiotic features: } \\
\text {-Complete information on the abiotic features: } 0.4 \text { points } \\
\text { *Geology: } 0.3 \text { points } \\
\text {-Edafology: } 0.05 \text { points } \\
\text {-Lithology: } 0.05 \text { points } \\
\text {-Geomorphology: } 0.05 \text { points } \\
\text {-Altitudes: } 0.033 \text { points }\end{array}$ \\
\hline
\end{tabular}




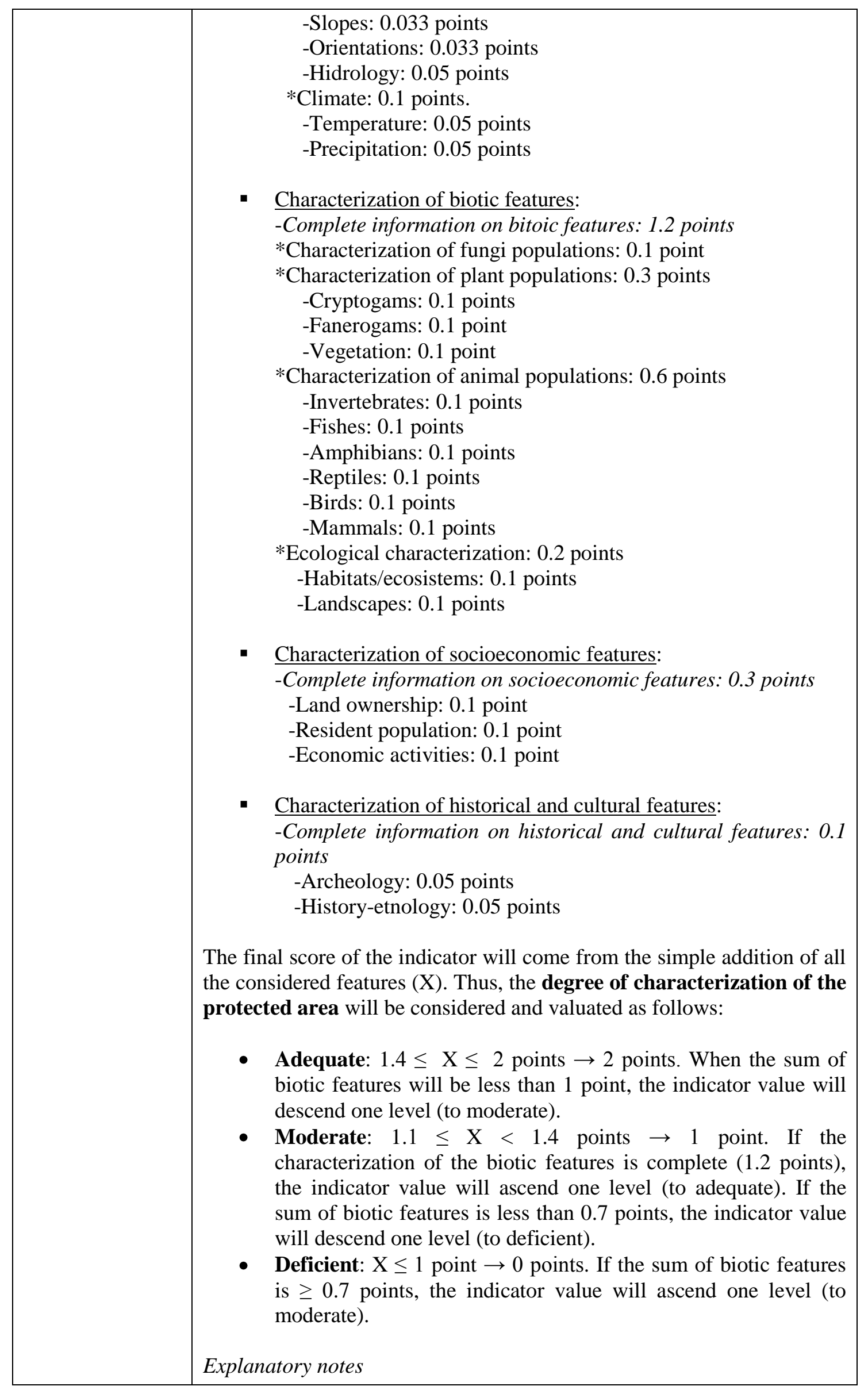




\begin{tabular}{|c|c|}
\hline & $\begin{array}{l}\text { It is considered "complete information" on any feature the detailed } \\
\text { characterization of that feature, independent of its lenght, in any } \\
\text { planning or management document, or in any scientific or technical } \\
\text { publication on the protected area. It is scored the total punctuation for } \\
\text { that complete feature. } \\
\text { It is considered "incomplete information" on any feature the partial } \\
\text { characterization of that feature, or when that feature is characterised at a } \\
\text { broader or finer scales than the area that feature covers within the PA. } \\
\text { Should this be the case, only half of the total score of the considered } \\
\text { feature will be given. } \\
\text { If there is no information on the considered feature or this information is } \\
\text { minimum or too diffuse, } 0 \text { points will be given. }\end{array}$ \\
\hline Tendency & $\begin{array}{l}\text { The tendency will be positive if the sum of the whole considered features } \\
\text { is higher than in the previous assessment, negative if the sum of the } \\
\text { biotic or socioeconomic features does not increase from the previous } \\
\text { assessment or if, being this score maximum in both assessment dates, the } \\
\text { information regarding any of those features has not been updated }\end{array}$ \\
\hline References & 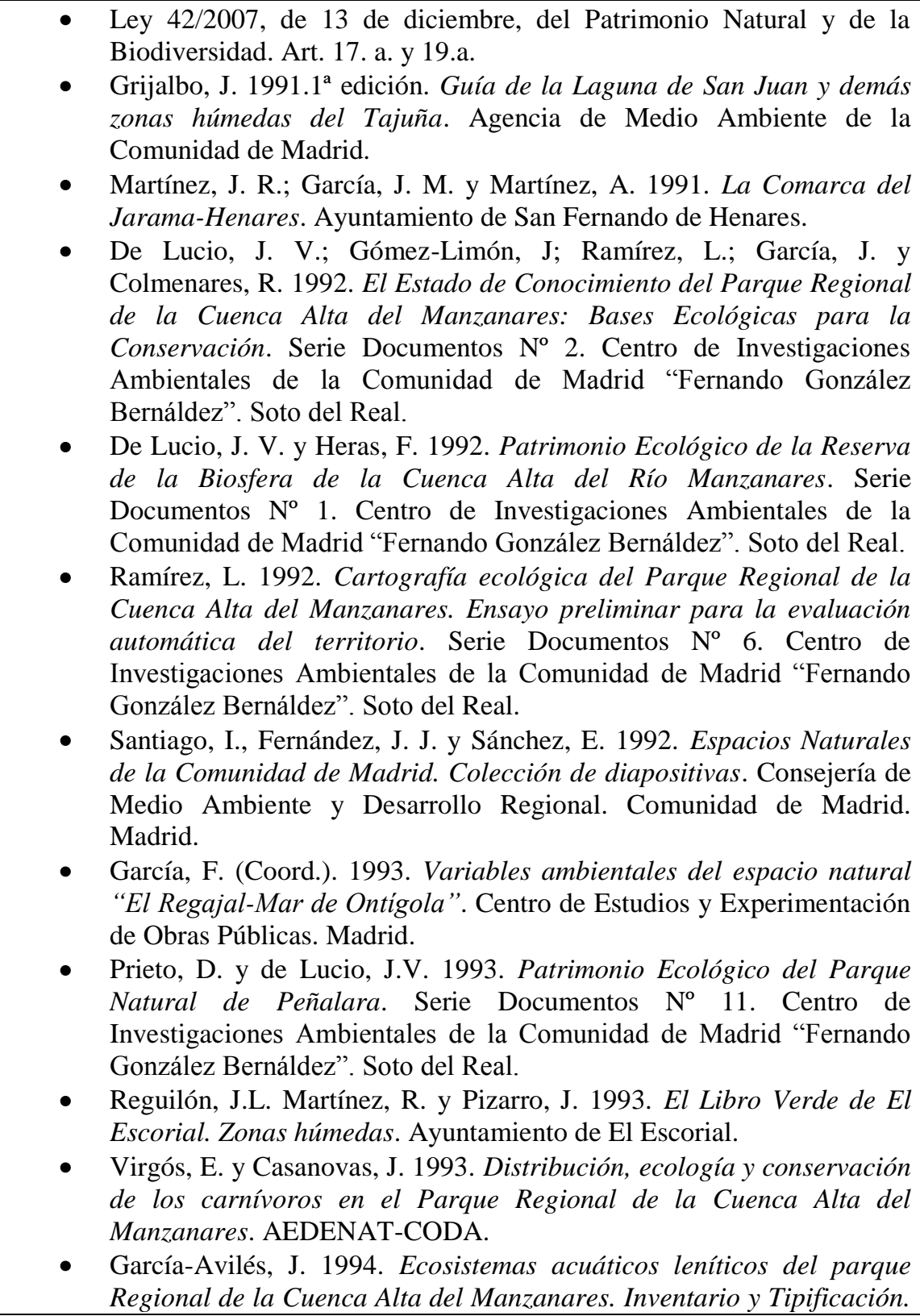 \\
\hline
\end{tabular}




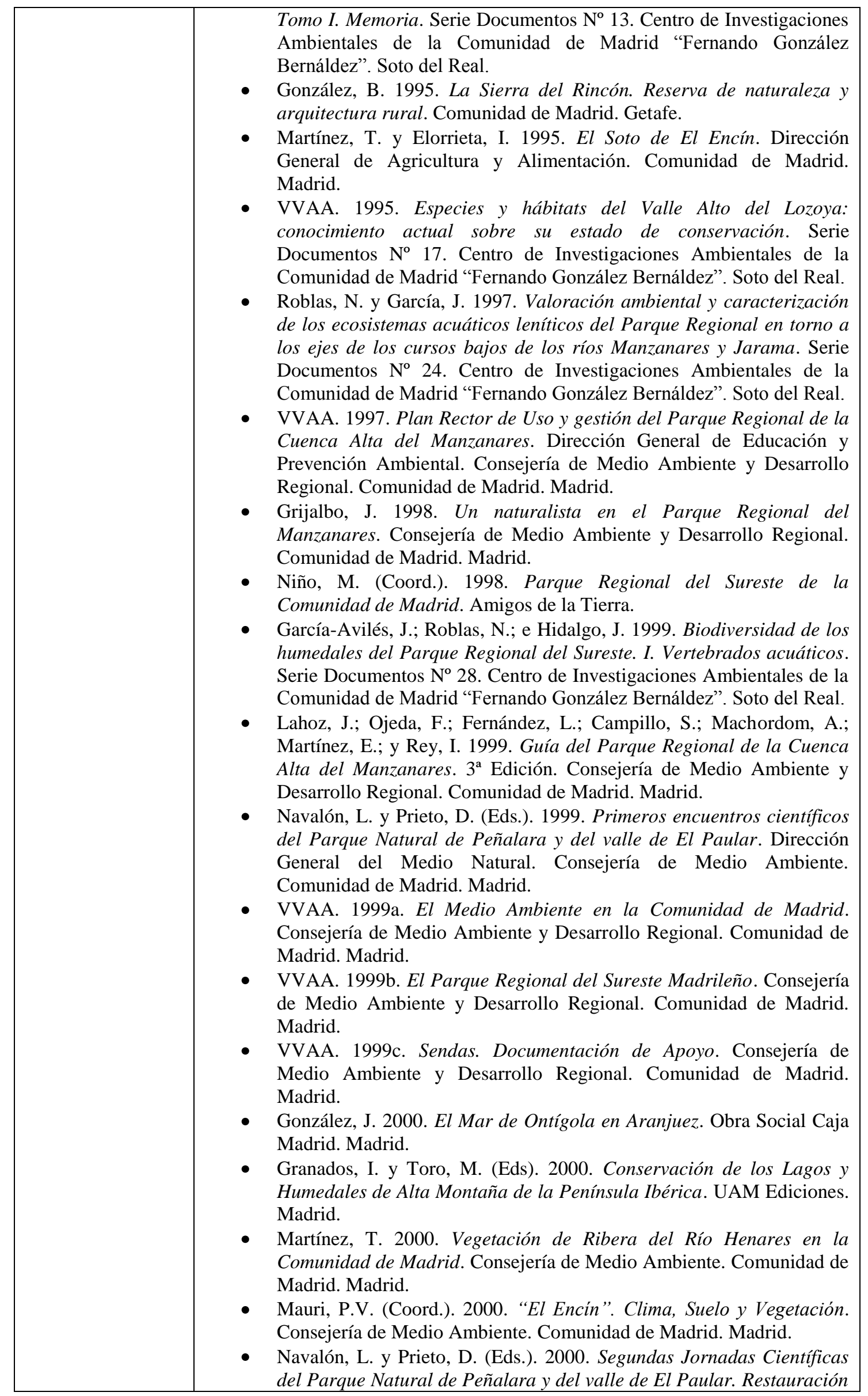




\begin{tabular}{|c|c|}
\hline & 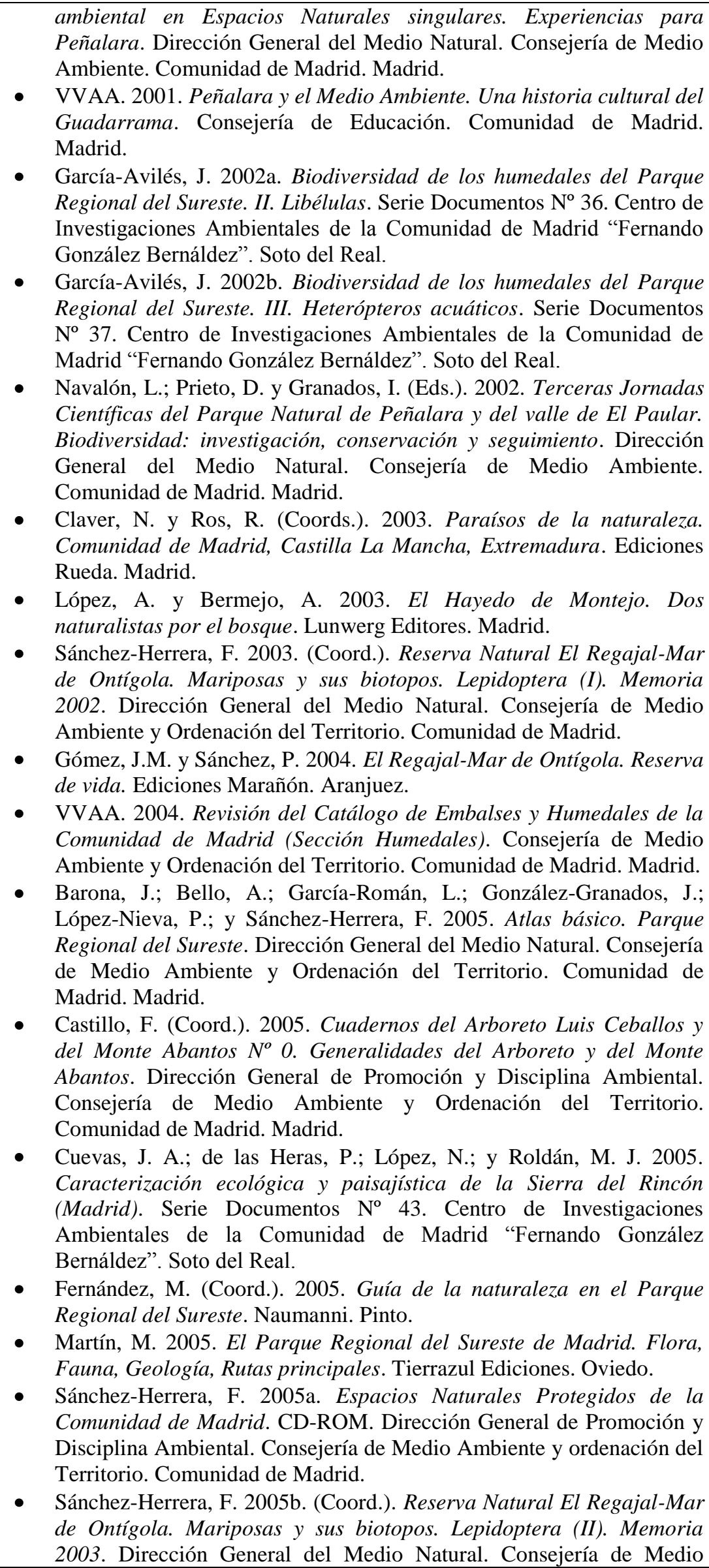 \\
\hline
\end{tabular}




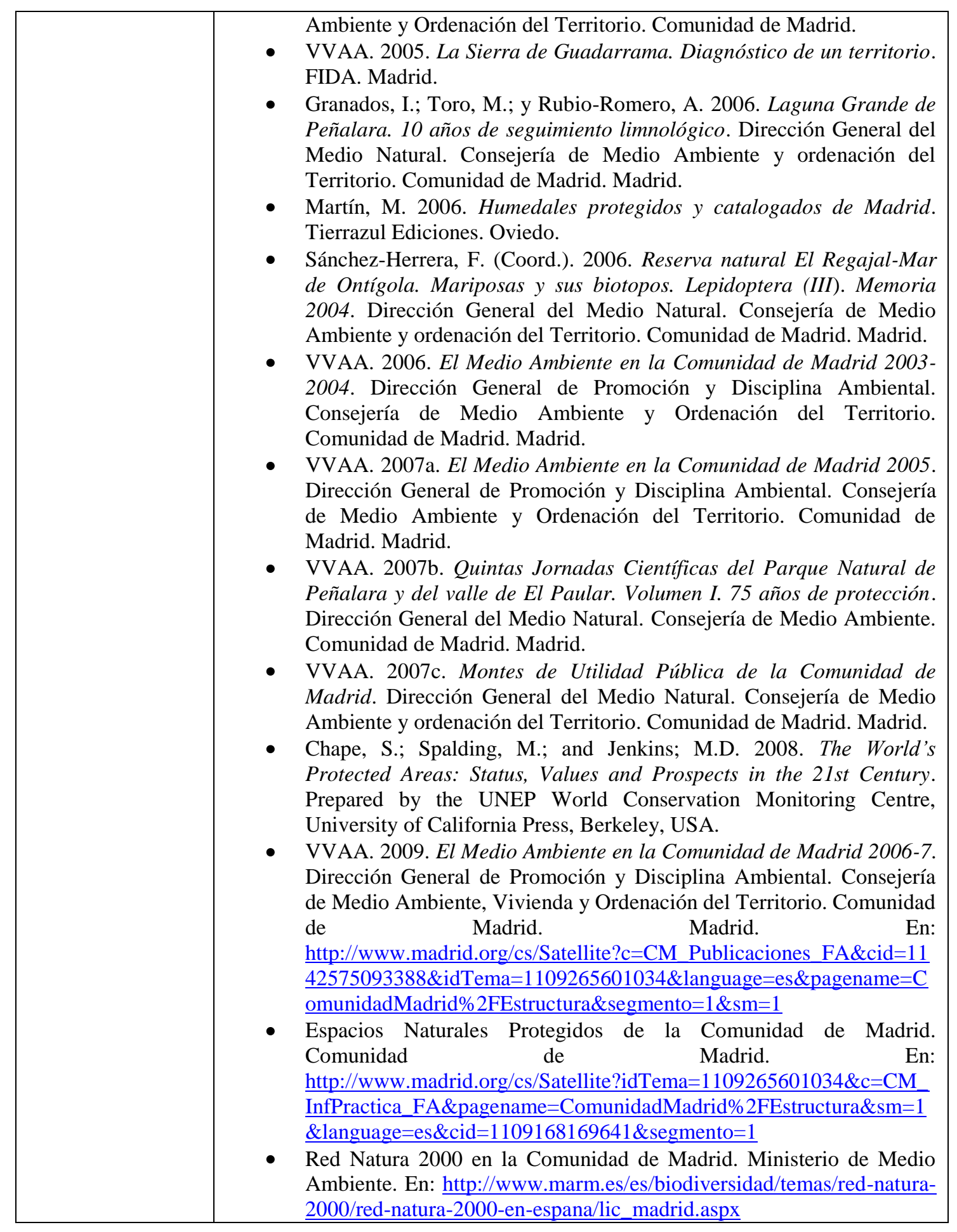

\begin{tabular}{|l|l|}
\hline 3.2. Degree of fulfilment of management objectives \\
\hline Category & Management \\
\hline Type & Response \\
\hline Description & $\begin{array}{l}\text { This indicator assesses the degree to which the objectives programmed } \\
\text { in the management documents of the protected area in force (workplan } \\
\text { or similar) were achieved }\end{array}$ \\
\hline
\end{tabular}




\begin{tabular}{|c|c|}
\hline Rationale & $\begin{array}{l}\text { Global change poses important challenges to protected areas, } \\
\text { necessitating active management to anticipate, prevent, mitigate or erase } \\
\text { the pressures and threats to these areas. In order for this management to } \\
\text { be really effective and adaptable to the changing needs of protected } \\
\text { areas (Chape et al., 2008), it is essential to assess whether, during a } \\
\text { defined period, the established management objectives have been } \\
\text { fulfilled and to correct the causes of partial or total non-fulfilment } \\
\text { (Múgica and Gómez-Limón, 2002; Mulero, 2002; Atauri et al., 2005; } \\
\text { Hockings et al., 2006). The establishment and evolution of clearly } \\
\text { defined, adaptable objectives allow managers to detect uncertainties and } \\
\text { irregularities, to manage complex situations in a simple way with the } \\
\text { support of science, to support and decentralize their decisions and to } \\
\text { learn from their errors (Chape et al., 2008). }\end{array}$ \\
\hline \multicolumn{2}{|l|}{ Data source } \\
\hline \multicolumn{2}{|l|}{ Data availability } \\
\hline Updating & Annual \\
\hline Scale & Ordinal scale, from 0 to 2 \\
\hline $\begin{array}{l}\text { Calculation and } \\
\text { interpretation }\end{array}$ & $\begin{array}{l}\text { If the management objectives are measurable, the percentage of } \\
\text { fulfilment will be measured. If not, the main manager (director or } \\
\text { similar) will be interviewed about the degree of fulfilment. } \\
\text { The degree of fulfilment of management objectives (X) will be } \\
\text { considered and valuated as follows: } \\
\text { - Adequate: } X \geq 75 \% \text { for the year of assessment } \rightarrow 2 \text { points } \\
\text { - Moderate: } 50 \% \leq X<75 \% \text { for the year of assessment } \rightarrow 1 \\
\text { point } \\
\text { Deficient: } X<50 \% \text { for the year of assessment } \rightarrow 0 \text { points } \\
\text { Explanatory note } \\
\text { "Management objectives" should be included in a written document, be } \\
\text { this document public or internal. } \\
\text { If such document does not exist, (workplan or similar, with a maximum } \\
\text { validity period of } 3 \text { years), or when the PA has no appointed manager } \\
\text { (director or similar) who can estimate globally the annual degree of } \\
\text { fulfilment of its management objectives, the indicator will be valuated } 0 \\
\text { points. }\end{array}$ \\
\hline Tendency & $\begin{array}{l}\text { The tendency will be positive if the value of the indicator is higher than } \\
\text { the previous assessment, stable if it is the same in both assessments, and } \\
\text { negative if it is smaller than the previous assessment }\end{array}$ \\
\hline References & 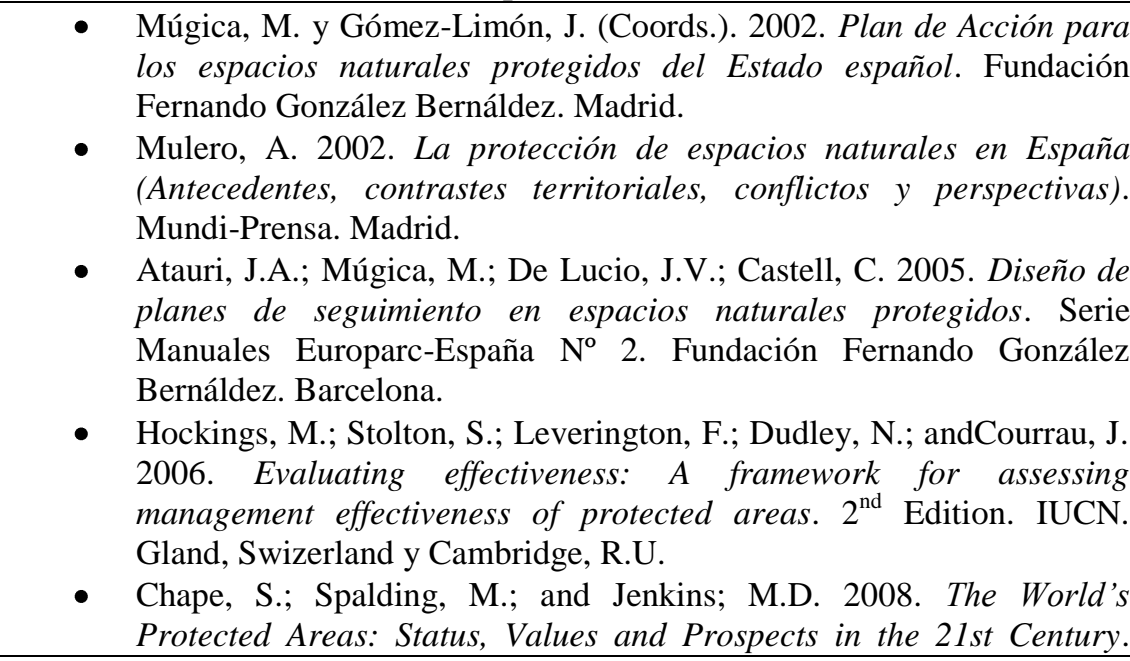 \\
\hline
\end{tabular}




\begin{tabular}{|l|l|}
\hline & $\begin{array}{l}\text { Prepared by the UNEP World Conservation Monitoring Centre, } \\
\text { University of California Press, Berkeley, USA. }\end{array}$ \\
\hline
\end{tabular}

\begin{tabular}{|c|c|}
\hline \multicolumn{2}{|c|}{ 3.3. Evolution of the feature (s) for which the protected area was designated } \\
\hline Category & Management \\
\hline Type & Response \\
\hline Description & $\begin{array}{l}\text { This indicator assesses the tendency of the feature(s) determining the } \\
\text { designation of the protected area, according to its designation norm }\end{array}$ \\
\hline Rationale & $\begin{array}{l}\text { The priority of any protected area should consist of improving the state } \\
\text { of conservation of the feature/s which motivated its designation, as well } \\
\text { as assessing its/their evolution in time, as the main indicator of the } \\
\text { efficiency of the PA (Pullin, 2002; Cuevas, 2003) }\end{array}$ \\
\hline \multicolumn{2}{|r|}{ 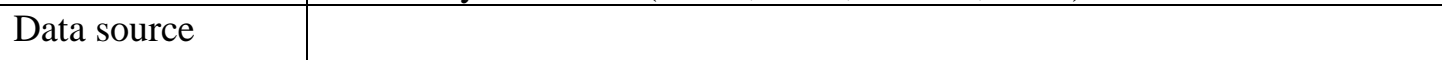 } \\
\hline \multicolumn{2}{|l|}{ Data availability } \\
\hline Updating & $\begin{array}{l}\text { Annually or every two years for biotic features. Every three or five years } \\
\text { for abiotic features }\end{array}$ \\
\hline Scale & Ordinal scale, from 0 to 2 \\
\hline $\begin{array}{l}\text { Calculation and } \\
\text { interpretation }\end{array}$ & $\begin{array}{l}\text { For each feature, a three-degree ordinal scale will be established. It will } \\
\text { be valuated from } 0 \text { to } 2 \text { points: } \\
\text { - Positive tendency of the feature: } 2 \text { points } \\
\text { - Stable tendency of the feature: } 1 \text { point } \\
\text { If there are different features, the results will be shown in a table. A } \\
\text { weighted average in which biotic features will be scored double than } \\
\text { abiotic features (X) will be done: } \\
\text { X }=\left(\sum \text { bf x } 2+\sum \text { af) / n1+n2), where }\right. \\
\text { bf: biotic features. } \\
\text { af: abiotic features. } \\
\text { n1: number of biotic features } \\
\text { n2: number of abiotic features } \\
\text { The global evolution of the feature/s for which the PA was } \\
\text { designated will be considered and valuated as follows: } \\
\text { - Adequate: } 2 \text { points } \\
\text { - Moderate: } 1 \text { point } \\
\text { - Deficient: } 0 \text { points } \\
\text { Explanatory note } \\
\text { It is considered "positive tendency" the increase in numbers or quality } \\
\text { ( }>5 \%) \text { of the considered feature since the designation of the protected } \\
\text { area or the first available data. It is considered "stable tendency" the } \\
\text { stabilization of the considered feature in terms of numbers or quality } \\
\text { (+/- } 5 \% \text { ) since the designation of the protected area or the first available } \\
\text { data, or the oscillation of its value if no continuous tendency towards } \\
\text { increase or decrease is observed ( } \geq 3 \text { consecutive years). }\end{array}$ \\
\hline
\end{tabular}




\begin{tabular}{|c|c|}
\hline & $\begin{array}{l}\text { It is considered "negative tendency" the decrease in numbers or quality } \\
(<5 \%) \text { of the considered feature since the designation of the protected } \\
\text { area or the first available data. For those features without previous data, } \\
\text { the tendency will be considered "non aplicable" and valuated } 0 \text { points. }\end{array}$ \\
\hline Tendency & $\begin{array}{l}\text { The tendency will be positive if the value of the indicator is higher than } \\
\text { in the previous assessment, stable if it is the same in the two } \\
\text { assessments, and negative if the most recent value is lower than the } \\
\text { previous one }\end{array}$ \\
\hline References & $\begin{array}{l}\text { - Cessford y Muhar, 2003. Monitoring options for visitor numbers in } \\
\text { national parks and natural areas. Journal for Nature Conservation, 11: 240- } \\
250 \text {. } \\
\text { - Pullin, A. 2002. Conservation Biology. Cambridge University Press. } \\
\text { Cambridge, UK. } \\
\text { - Cuevas, J. A. 2003. Inventario y Description de los hábitats } \\
\text { incluidos en la Directiva 92/43/CEE presentes en la Comunidad de Madrid. } \\
\text { Serie Documentos } \mathrm{n}^{\circ} 40 \text {. Centro de Investigaciones Ambientales de la } \\
\text { Comunidad de Madrid Fernando González Bernáldez. Soto del Real. } \\
\text { - Hockings, M.; Stolton, S.; Leverington, F.; Dudley, N.; and Courrau, J. } \\
\text { 2006. Evaluating effectiveness: A framework for assessing management } \\
\text { effectiveness of protected areas. } 2^{\text {nd }} \text { Edition. IUCN. Gland, Swizerland y } \\
\text { Cambridge, R.U. }\end{array}$ \\
\hline
\end{tabular}

\begin{tabular}{|c|c|}
\hline Category & Management \\
\hline Type & Response \\
\hline Description & $\begin{array}{l}\text { This indicator assesses whether there is enough staff to manage the } \\
\text { protected area }\end{array}$ \\
\hline Rationale & $\begin{array}{l}\text { The existence of a legally established management body allows } \\
\text { professional, effective, responsible management of a protected area } \\
\text { (Pomeroy et al., 2005). Management requires complete, continuous } \\
\text { dedication, with rapid action to prevent sudden contingencies (Chape et } \\
\text { al., 2008) and to ensure compliance with regulations (Pomeroy et al., } \\
\text { 2005). Thus, the existence of sufficient staff is considered a basis for the } \\
\text { effective management of protected areas (Múgica and Gómez-Limón, } \\
\text { 2002; Carabias et al., 2004). Lack of sufficient staff is considered to be } \\
\text { the commonest weakness of protected areas around the world (Leverigton } \\
\text { et al., 2010; Nolte et al., 2010). }\end{array}$ \\
\hline \multicolumn{2}{|l|}{ Data source } \\
\hline \multicolumn{2}{|l|}{ Data availability } \\
\hline Updating & Every four years \\
\hline Scale & Ordinal scale, from 0 to 2 \\
\hline $\begin{array}{l}\text { Calculation and } \\
\text { interpretation }\end{array}$ & $\begin{array}{l}\text { The existence of fixed-position staff (independent of the type of contract) } \\
\text { necessary for the effective management of the protected area, developing } \\
\text { their jobs in the same protected area in the long term (not to cover } \\
\text { temporal projects or needs) will be specified. } \\
\text { The score of the indicator will be calculated from the simple addition of } \\
\text { the score out of the presence of a director or technical manager, and the } \\
\text { score out of the presence of surveillance staff in the protected area, } \\
\text { depending on the type of protected area. }\end{array}$ \\
\hline
\end{tabular}




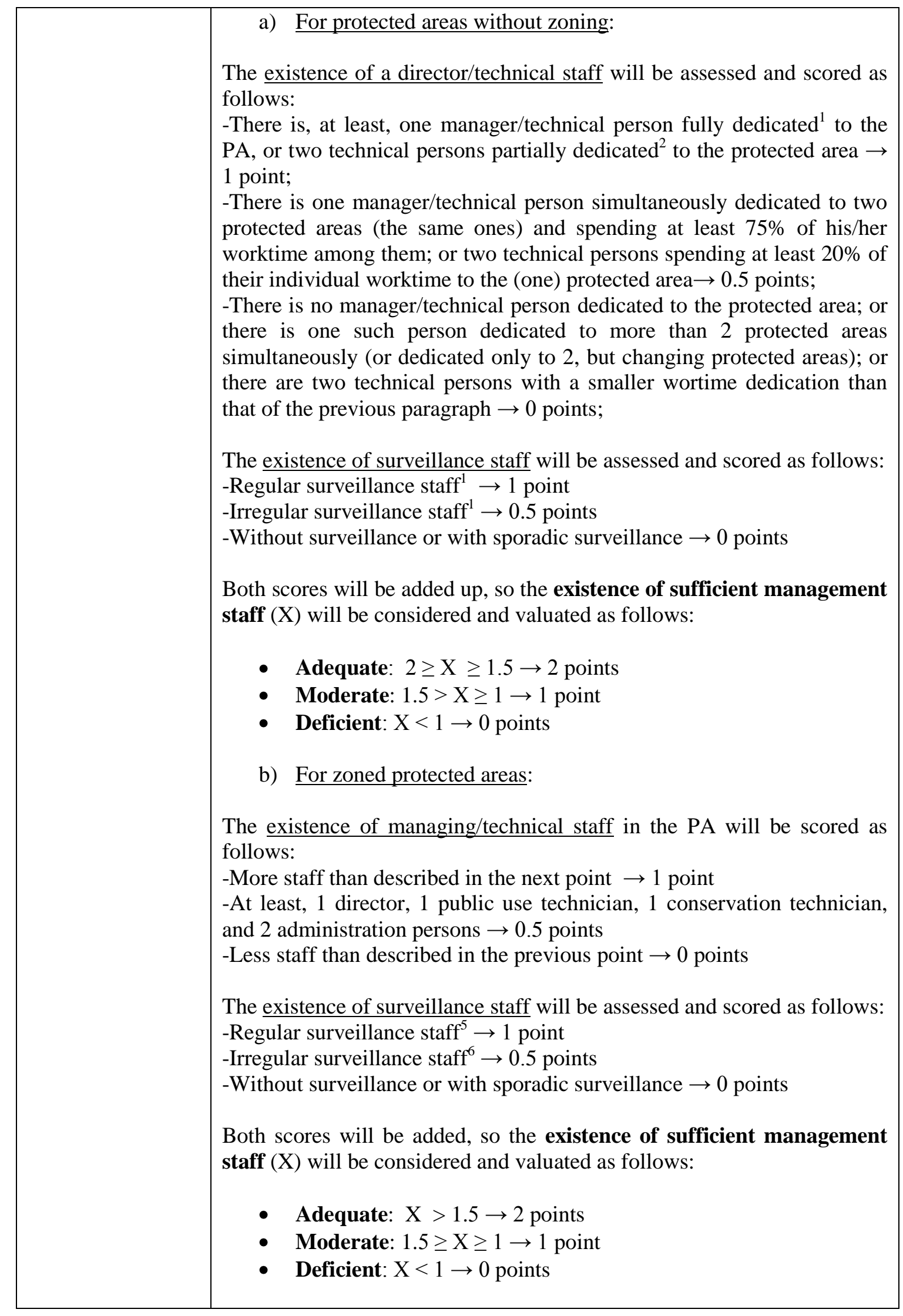




\begin{tabular}{|c|c|}
\hline & $\begin{array}{l}\text { Explanatory note (for protected areas without zoning) } \\
{ }^{1} \text { It is considered that a person is "fully dedicated" to the management of a } \\
\text { PA when he/she dedicates at least } 75 \% \text { of his/her worktime to the } \\
\text { protected area. } \\
\text { } \text { It si considered that a person is "partially dedicated" to the management } \\
\text { of a protected area when he/she dedicates at least } 40 \% \text { of his/her } \\
\text { worktime to the protected area. } \\
{ }^{3} \text { It is considered as "regular surveillance" the patrol of the protected area } \\
\text { at least } 4 \text { days per week. } \\
{ }^{4} \text { It is considered as "irregular surveillance" the patrol frequency smaller } \\
\text { than that of the previous point, but at least of } 2 \text { days per week. } \\
\text { Explanatory note (for zoned protected areas): } \\
\text { "It is considered as "regular surveillance" the patrol of the protected area } \\
7 \text { days a week. } \\
\text { "It is considered as "irregular surveillance" the patrol of the protected } \\
\text { area at least } 5 \text { days per week. }\end{array}$ \\
\hline Tendency & $\begin{array}{l}\text { The tendency will be positive if } \mathrm{X} \text { increases between both analyzed } \\
\text { periods, stable if } \mathrm{X} \text { remains the same, and negative if } \mathrm{X} \text { decreases }\end{array}$ \\
\hline References & $\begin{array}{l}\text { - Múgica, M. y Gómez-Limón, J. (Coords.). 2002. Plan de Acción para } \\
\text { los espacios naturales protegidos del Estado español. Fundación } \\
\text { Fernando González Bernáldez. Madrid. } \\
\text { Carabias, J.; Boness, M.; De la Maza, J.; and Cadena, R. 2004. Buiding } \\
\text { capacity to manage protected areas in an era of global change. In } \\
\text { Barber, C.V.; Miller, K.R.; and Bones, M. (Eds.). Securing Protected } \\
\text { Areas in the Face of Global Change: Issues and Strategies. IUCN. } \\
\text { Gland, Switzerland and Cambridge, UK. } \\
\text { - Pomeroy, R.S., Parks, J.E.; and Watson, L.M. 2005. How is your MPA } \\
\text { doing? A methodology for evaluating the management effectiveness of } \\
\text { marine protected areas. IUCN, Gland, Switzerland, and Cambridge, } \\
\text { United Kingdom. } \\
\text { Chape, S.; Spalding, M.; and Jenkins; M.D. 2008. The World's } \\
\text { Protected Areas: Status, Values and Prospects in the 21st Century. } \\
\text { Prepared by the UNEP World Conservation Monitoring Centre, } \\
\text { University of California Press, Berkeley, USA. } \\
\text { Mallarach, J.M.; Germain, J.; Sabaté, X.; y Basora, X. 2008. Protegits } \\
\text { de fet o de dret? Primera avaluació del sistema d'espais naturals } \\
\text { protegits de Catalunya. Institució Catalana d'Historia Natural. } \\
\text { Disponible } \\
\text { http://ichn.iec.cat/Avaluaci\%C3\%B3\%20d\%27espais.htm } \\
\text { Leverington, F.; Lemos, K.; Courrau, J.; Pavese, H.; Nolte, C.; Marr, } \\
\text { M.; Coad, L.; Burguess, N.; Bomhard, B.; \& Hockings, M. 2010. } \\
\text { Management effectiveness evaluation in protected areas - a global } \\
\text { study. Second Edition 2010. University of Queensland. Brisbane. } \\
\text { Nolte, C.; Leverington, F.; Kettner, A.; Marr, M.; Nielsen, G.; } \\
\text { Bomhard, B.; Stolton, S.; Stoll-Kleemann, S.; \& Hockings, M. 2010. } \\
\text { Protected Area Management Effectiveness Assessments in Europe. A } \\
\text { review of application, methods and results. University of Greifswald. } \\
\text { Greifswald, Germany. }\end{array}$ \\
\hline
\end{tabular}

\subsection{Evolution of the investment in the protected area}

\begin{tabular}{|l|l}
\hline Category & Management \\
\hline
\end{tabular}




\begin{tabular}{|c|c|}
\hline Type & Response \\
\hline Description & $\begin{array}{l}\text { This indicator assesses the evolution of the investment budget in the } \\
\text { protected area }\end{array}$ \\
\hline Rationale & $\begin{array}{l}\text { The existence of sufficient, stable and enduring financing is fundamental } \\
\text { for the efficient management of protected areas (Chape et al., 2008; } \\
\text { Leverington et al., 2010; Mora and Sale, 2011). It is one of the minimum } \\
\text { international standards for individual protected areas (Carabias et al., } \\
\text { 2004) }\end{array}$ \\
\hline \multicolumn{2}{|r|}{ (2: } \\
\hline \multicolumn{2}{|l|}{ Data availability } \\
\hline Updating & Annually \\
\hline Scale & Ordinal scale, from 0 to 2 \\
\hline $\begin{array}{l}\text { Calculation and } \\
\text { interpretation }\end{array}$ & $\begin{array}{l}\text { The evolution of the investment in the PA* will be measured since the } \\
\text { designation of the protected area or since the first available data. } \\
\text { The evolution of the investment in the PA will be considered and } \\
\text { valuated as follows: } \\
\text { - Adequate: when the average increase in the investment for the } \\
\text { period of analysis }(\mathrm{X}) \text { is equal or over }+3 \% \text { per annum, } \\
\text { calculated on the same parameters and measurement methods } \rightarrow \\
2 \text { points } \\
\text { - Moderate: when }+1 \%<\mathrm{X}<+3 \% \text { per annum, calculated on the } \\
\text { same parameters and measurement methods. Punctual, non- } \\
\text { consecutive investments in the last } 3 \text { years including the } \\
\text { assessment year will also be considered "moderate" } \rightarrow 1 \text { point } \\
\text { - Deficient: when X }<+1 \% \text { per annum, calculated on the same } \\
\text { parameters and measurement methods } \rightarrow 0 \text { points } \\
\text { Explanatory note } \\
\text { *It will only be considered as "investment" the real investments in the } \\
\text { protected area, not running costs or fixed costs. } \\
\text { A } 3 \% \text { annual increase is applied as a standard reference of the inter- } \\
\text { annual increase of prices (RPI). }\end{array}$ \\
\hline Tendency & $\begin{array}{l}\text { The tendency will be considered positive if there has been an inter-annual } \\
\text { average increase equal or over }+3 \% \text { between the value of the last } \\
\text { assessment and the value of the previous assessment. The tendency will } \\
\text { be stable if } X \text { oscillates between }+1 \%<X<+3 \% \text { per annum between } \\
\text { both dates, and it will be negative if } X<1 \% \text { per annum in that period }\end{array}$ \\
\hline References & $\begin{array}{l}\text { - Carabias, J.; Boness, M.; De la Maza, J.; and Cadena, R. 2004. Buiding } \\
\text { capacity to manage protected areas in an era of global change. In } \\
\text { Barber, C.V.; Miller, K.R.; and Bones, M. (Eds.). Securing Protected } \\
\text { Areas in the Face of Global Change: Issues and Strategies. IUCN. } \\
\text { Gland, Switzerland and Cambridge, UK. } \\
\text { Chape, S.; Spalding, M.; and Jenkins; M.D. 2008. The World's } \\
\text { Protected Areas: Status, Values and Prospects in the 21st Century. } \\
\text { Prepared by the UNEP World Conservation Monitoring Centre, } \\
\text { University of California Press, Berkeley, USA. } \\
\text { Mallarach, J.M.; Germain, J.; Sabaté, X.; y Basora, X. 2008. Protegits } \\
\text { de fet o de dret? Primera avaluació del sistema d'espais naturals } \\
\text { protegits de Catalunya. Institució Catalana d'Historia Natural. } \\
\text { Disponible } \\
\text { http://ichn.iec.cat/Avaluaci\%C3\%B3\%20d\%27espais.htm } \\
\text { Leverington, F.; Lemos, K.; Courrau, J.; Pavese, H.; Nolte, C.; Marr, } \\
\text { M.; Coad, L.; Burguess, N.; Bomhard, B.; \& Hockings, M. 2010. } \\
\text { Management effectiveness evaluation in protected areas - a global } \\
\text { study. Second Edition 2010. University of Queensland. Brisbane. }\end{array}$ \\
\hline
\end{tabular}




\begin{tabular}{|l|l|}
\hline & $\begin{array}{l}\text { Mora, C. and Sale, P.F. 2011. Ongoing global biodiversity loss and the } \\
\text { need to move beyond protected areas: a review of the technical and } \\
\text { practical shortcomings of protected areas on land and sea. Marine } \\
\text { Ecology Progress Series, 434: 251-266. }\end{array}$ \\
\hline
\end{tabular}

\begin{tabular}{|c|c|}
\hline \multicolumn{2}{|c|}{ 3.6. Effectiveness of the public participation bodies } \\
\hline Category & Management \\
\hline Type & Response \\
\hline Description & $\begin{array}{l}\text { This indicator assesses the existence of a public participation body and its } \\
\text { effectiveness }\end{array}$ \\
\hline Rationale & $\begin{array}{l}\text { An adequate social representation and participation in the management of } \\
\text { protected areas entails a deeper implication of society and a better } \\
\text { aceptance of the management decisions. This affects notably and } \\
\text { positively the effectiveness of management measures and thus, the } \\
\text { effective conservation of protected areas (Pomeroy et al., 2005). } \\
\text { Moreover, public participation is one of the minimum international } \\
\text { standards for individual protected areas (Carabias et al., 2004) }\end{array}$ \\
\hline \multicolumn{2}{|r|}{ 年 } \\
\hline \multicolumn{2}{|l|}{ Data availability } \\
\hline Updating & Annually \\
\hline Scale & Ordinal scale, from 0 to 2 \\
\hline $\begin{array}{l}\text { Calculation and } \\
\text { interpretation }\end{array}$ & $\begin{array}{l}\text { The effectiveness of the public participation bodies }(\mathrm{PPB}) \text { will be } \\
\text { considered and valuated according to the simple addition of the scores of } \\
\text { its two constituent parameters as follows: } \\
\text {-Regarding the existence of the PPB: } \\
\text { - Nonexistent: There is no PPB for the protected area } \rightarrow 0 \text { points. } \\
\text { - Existent: There is a PPB for the protected area } \rightarrow \text { its } \\
\text { effectiveness will be assessed } \\
\text {-Regarding its effectiveness: } \\
\text { For PAs without zoning: } \\
\text { - Adequate: More than one meeting every two years since the } \\
\text { creation of the PPB or since the last assessment } \rightarrow 2 \text { points } \\
\text { - Moderate: One meeting every two years since the creation of the } \\
\text { PPB or since the last assessment } \rightarrow 1 \text { point } \\
\text { - Deficient: Less than one meeting every two years since the } \\
\text { creation of the PPB or since the last assessment } \rightarrow 0 \text { points } \\
\text { For zoned protected areas: } \\
\text { - Adequate: More than one meeting per year since the creation of } \\
\text { the PPB or since the last assessment } \rightarrow 2 \text { points } \\
\text { - Moderate: One meeting per year since the creation of the PPB or } \\
\text { since the last assessment } \rightarrow 1 \text { point } \\
\text { Deficient: Less than one meeting per year since the creation of } \\
\text { the PPB or since the last assessment } \rightarrow 0 \text { points }\end{array}$ \\
\hline Tendency & $\begin{array}{l}\text { The tendency will be considered positive if a PPB has been created or if } \\
\text { the meeting frequency has increased since the last date analyzed. The } \\
\text { tendency will be stable if both the existence and the meeting frequency } \\
\text { are the same, and it will be negative if the PPB is eliminated or if the } \\
\text { meeting frequency has decreased since the last date analyzed }\end{array}$ \\
\hline References & $\begin{array}{l}\text { - Carabias, J.; Boness, M.; De la Maza, J.; and Cadena, R. 2004. Buiding } \\
\text { capacity to manage protected areas in an era of global change. In }\end{array}$ \\
\hline
\end{tabular}




\begin{tabular}{|l|l|}
\hline & Barber, C.V.; Miller, K.R.; and Bones, M. (Eds.). Securing Protected \\
& Areas in the Face of Global Change: Issues and Strategies. IUCN. \\
& Gland, Switzerland and Cambridge, UK. \\
- & Pomeroy, R.S., Parks, J.E.; and Watson, L.M. 2005. How is your MPA \\
& doing? A methodology for evaluating the management effectiveness of \\
& marine protected areas. IUCN, Gland, Switzerland, and Cambridge, \\
& United Kingdom. \\
- & Mallarach, J.M.; Germain, J.; Sabaté, X.; y Basora, X. 2008. Protegits \\
& de fet o de dret? Primera avaluació del sistema d'espais naturals \\
protegits de Catalunya. Institució Catalana d'Història Natural. & en: \\
& Disponible \\
http://ichn.iec.cat/Avaluaci\%C3\%B3\%20d\%27espais.htm & \\
\hline
\end{tabular}

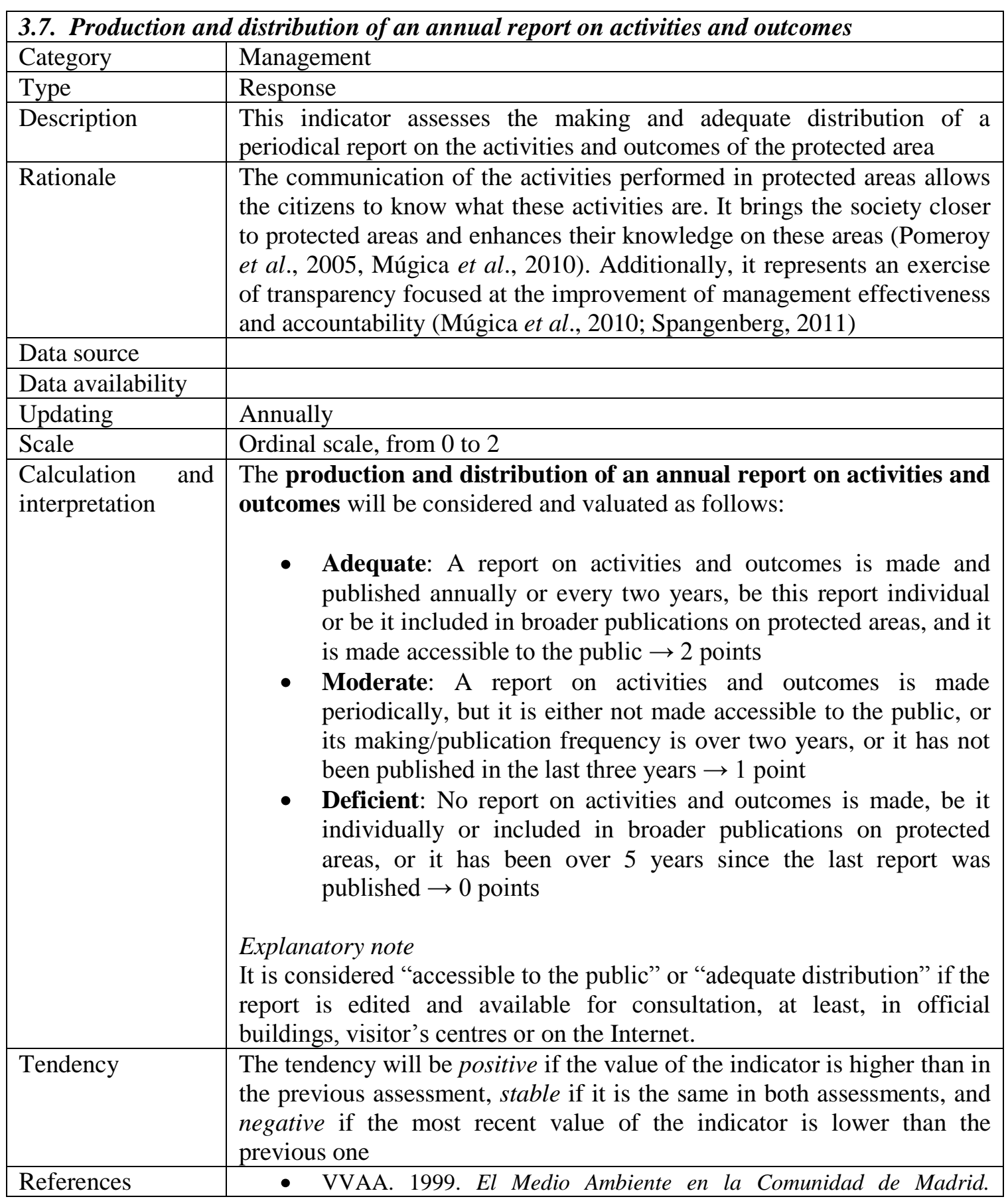




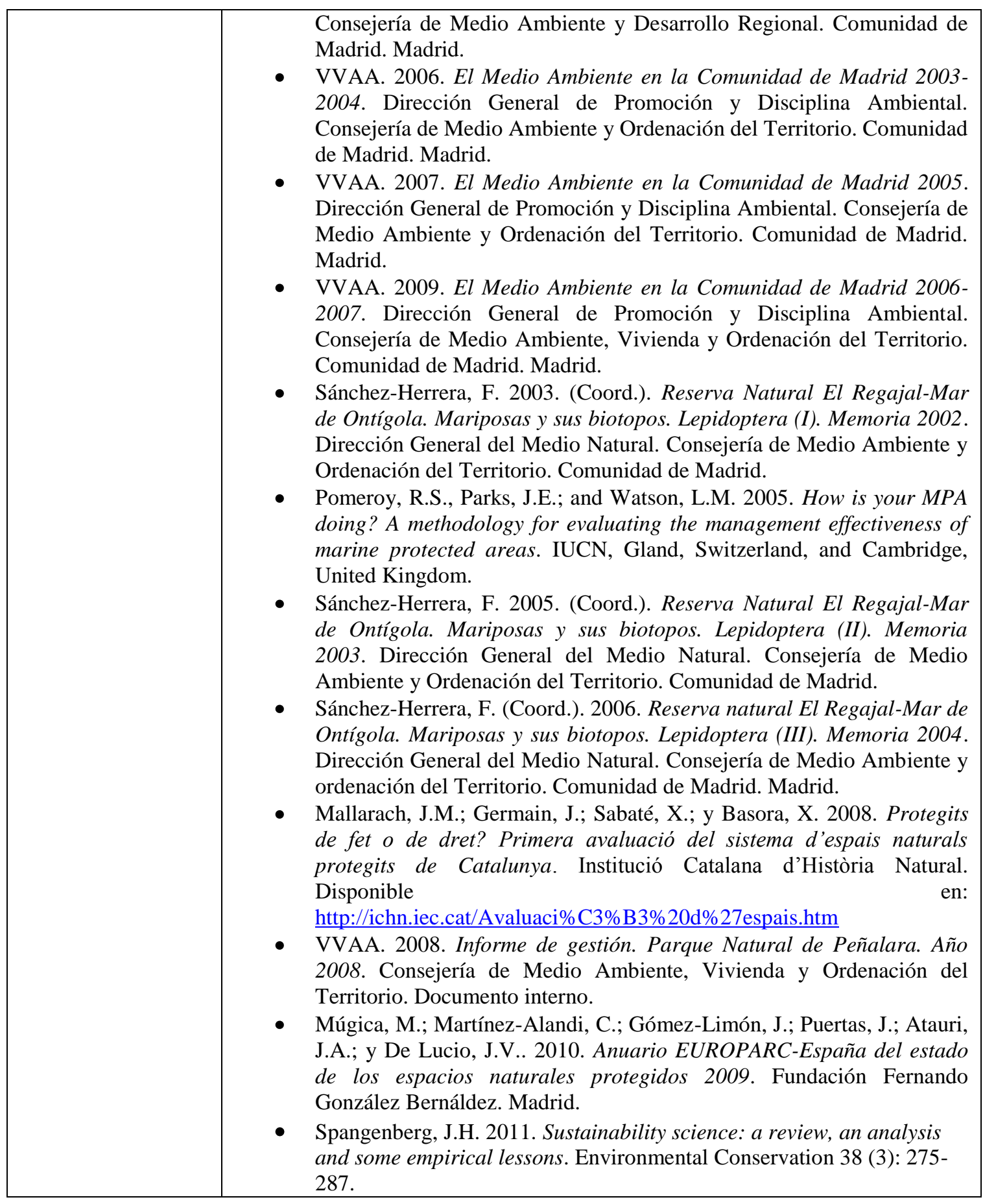

\begin{tabular}{|l|l|}
\hline 3.8. Easiness to identify the protected area \\
\hline Category & Management \\
\hline Type & Response \\
\hline Description & $\begin{array}{l}\text { This indicator assesses the easiness to identify in situ the limits of the } \\
\text { protected area }\end{array}$ \\
\hline Rationale & $\begin{array}{l}\text { An appropriate identification of protected areas, at least at the points of } \\
\text { maximum influx of visitors, informs the visitor or the potential offender } \\
\text { of the difference of developing his/her activity inside a protected area. It } \\
\text { should favour an environmentally sound behaviour among visitors and } \\
\text { thus, facilitate management and effective conservation of these areas. It is }\end{array}$ \\
\hline
\end{tabular}




\begin{tabular}{|c|c|}
\hline & $\begin{array}{l}\text { also one of the minimum international standards for individual protected } \\
\text { areas (Carabias et al., 2004). }\end{array}$ \\
\hline Data source & Visits \\
\hline Data availability & \\
\hline Updating & Every four years \\
\hline Scale & Ordinal scale, from 0 to 2 \\
\hline $\begin{array}{l}\text { Calculation and } \\
\text { interpretation }\end{array}$ & $\begin{array}{l}\text { The signaling of every sensitive point* will be assessed, scoring each } \\
\text { sensitive point individually as follows: } \\
\text { - The signaling identifies perfectly the protected area and it is } \\
\text { homogeneous** } \rightarrow 2 \text { points } \\
\text { - There is signaling identifying the protected area, but it is not } \\
\text { homogeneous } \rightarrow 1 \text { point } \\
\text { - There is no signaling identifying the protected area } \rightarrow 0 \text { points } \\
\text { The easiness to identifify the protected area will be considered and } \\
\text { valuated as follows. The final value of the indicator will come from the } \\
\text { average of the values of every sensitive point in the protected area }(X) \text { : } \\
\text { - Adequate: The signaling identifies the protected area perfectly in } \\
\text { all its sensitive points, and it is homogeneous: } X \geq 1.5 \rightarrow 2 \text { points } \\
\text { Moderate: there is signaling in the protected area, but it is } \\
\text { restricted to the main accesses to the protected area, or it } \\
\text { identifies the protected area perfectly in all its sensitive points but } \\
\text { it is not homogeneous: } 1 \leq X<1.5 \rightarrow 1 \text { point } \\
\text { - Deficient: there is no signaling identifying the protected area: } X \\
<1 \rightarrow 0 \text { points } \\
\text { Explanatory note } \\
\text { *It is considered "sensitive points" those places inside or on the perimeter } \\
\text { of the protectd area where relevant concentrations of visitors take place: } \\
\text { accesses, picnic areas and visitors centres. } \\
* * \text { It is considered "homogeneous signaling" the signaling which fulfils } \\
\text { the signaling requirements or standards established in the law, in } \\
\text { protected area management documents or in the guidelines of the network } \\
\text { it belongs to. }\end{array}$ \\
\hline Tendency & $\begin{array}{l}\text { The tendency will be positive if } \mathrm{X} \text { is higher than in the previous } \\
\text { assessment, stable if } \mathrm{X} \text { is the same in both assessments, and negative if } \mathrm{X} \\
\text { is lower than the previous assessment }\end{array}$ \\
\hline References & $\begin{array}{l}\text { - Sánchez-Herrera, F. 2003. Señalización de los Espacios Naturales de la } \\
\text { Comunidad de Madrid. Extracto del Manual de Normas. Dirección } \\
\text { General del Medio Natural. Consejería de Medio Ambiente. Comunidad } \\
\text { de Madrid. } \\
\text { Carabias, J.; Boness, M.; De la Maza, J.; and Cadena, R. 2004. Buiding } \\
\text { capacity to manage protected areas in an era of global change. In } \\
\text { Barber, C.V.; Miller, K.R.; and Bones, M. (Eds.). Securing Protected } \\
\text { Areas in the Face of Global Change: Issues and Strategies. IUCN. } \\
\text { Gland, Switzerland and Cambridge, UK. } \\
\text { - Mallarach, J.M.; Germain, J.; Sabaté, X.; y Basora, X. 2008. Protegits } \\
\text { de fet o de dret? Primera avaluació del sistema d'espais naturals } \\
\text { protegits de Catalunya. Institució Catalana d'Història Natural. } \\
\text { Disponible } \\
\text { http://ichn.iec.cat/Avaluaci\%C3\%B3\%20d\%27espais.htm }\end{array}$ \\
\hline
\end{tabular}

3.9. Public use infrastructure 


\begin{tabular}{|c|c|}
\hline Category & Management \\
\hline Type & Response \\
\hline Description & $\begin{array}{l}\text { This indicator assesses the existence of public use infrastructures } \\
\text { adequate to the size of the protected area, and their maintenance }\end{array}$ \\
\hline Rationale & $\begin{array}{l}\text { Public use infrastructures presented in enough quantity, well-maintained } \\
\text { and oriented to the type of visitors to protected areas allow to direct } \\
\text { visitor influxes and to improve the quality of visits through information } \\
\text { and interpretation (Hernández y Gómez-Limón, 2005; Ortega et al., } \\
\text { 2006; Pascual, 2007). Appropriate infrastructures are one of the minimum } \\
\text { international standards for individual PAs (Carabias et al., 2004) }\end{array}$ \\
\hline Data source & \\
\hline Data availability & \\
\hline Updating & Every four years \\
\hline Scale & Ordinal scale, from 0 to 2 \\
\hline $\begin{array}{l}\text { Calculation and } \\
\text { interpretation }\end{array}$ & 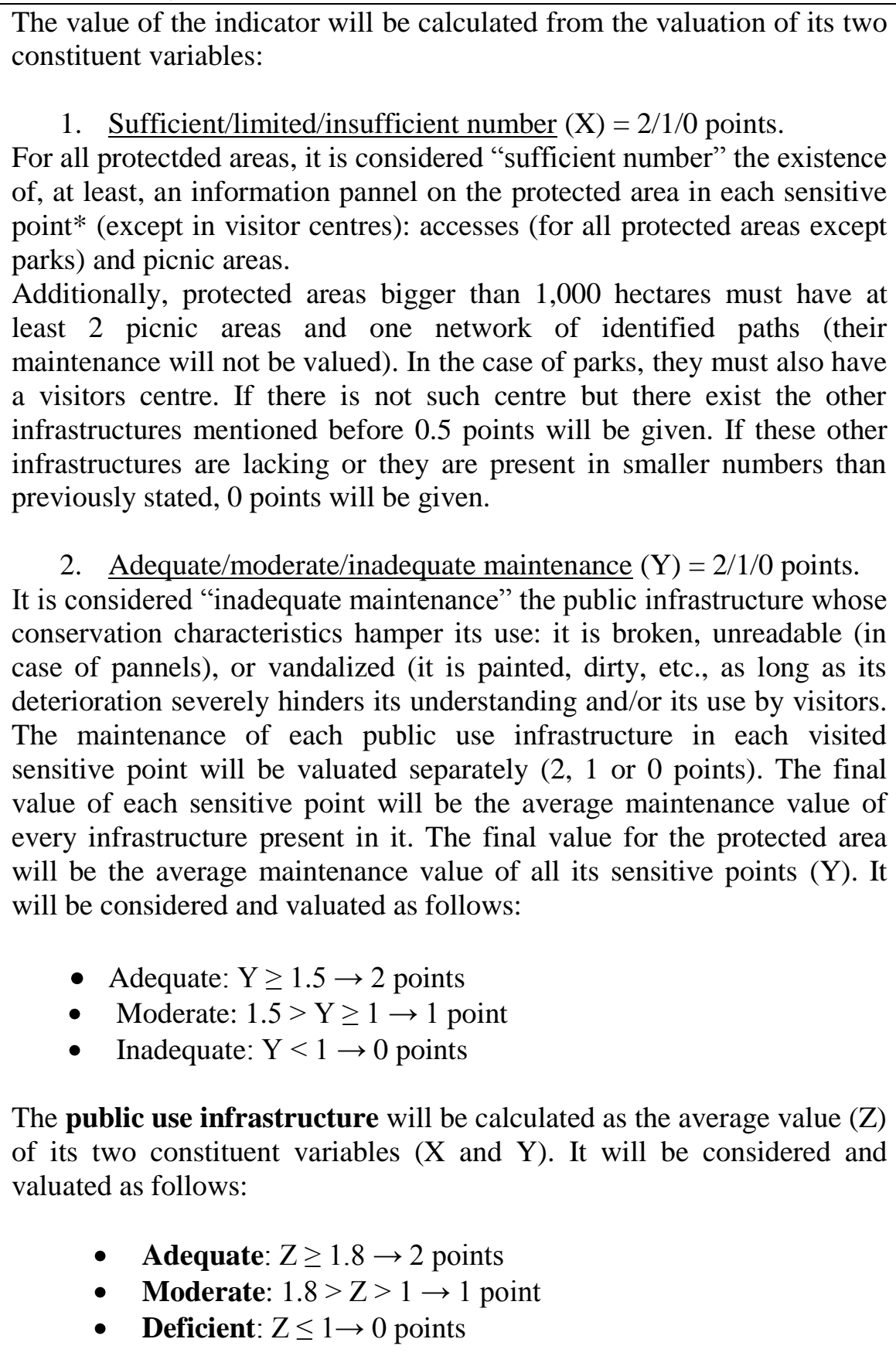 \\
\hline
\end{tabular}




\begin{tabular}{|l|l|}
\hline & $\begin{array}{l}\text { Explanatory note } \\
\text { *It is considered "sensitive points" the places inside or on the perimeter } \\
\text { of the protected area where relevant concentrations of visitors take place: } \\
\text { accesses, picnic areas and visitors centres. }\end{array}$ \\
\hline Thendency & $\begin{array}{l}\text { Thendency will be positive if } \mathrm{Z} \text { is higher than in the previous } \\
\text { assessment, stable if Z is the same in both assessments, and negative if Z } \\
\text { is smaller than its previous value }\end{array}$ \\
\hline References & $\begin{array}{l}\text { Carabias, J.; Boness, M.; De la Maza, J.; and Cadena, R. 2004. Buiding } \\
\text { capacity to manage protected areas in an era of global change. In } \\
\text { Barber, C.V.; Miller, K.R.; and Bones, M. (Eds.). Securing Protected } \\
\text { Areas in the Face of Global Change: Issues and Strategies. IUCN. } \\
\text { Gland, Switzerland and Cambridge, UK. } \\
\text { Hernández, J. y Gómez-Limón, J. 2005. Manual sobre conceptos de uso } \\
\text { público en los espacios naturales protegidos. Fundación Fernando } \\
\text { González Bernáldez. Madrid. } \\
\text { Ortega, J.; Gómez-Limón, J.; Rovira, P.; López-Claramunt, A.; y } \\
\text { Gabaldón, J. E. 2006. Evaluación del papel que cumplen los } \\
\text { equipamientos de uso público en los ENPs. Fundación Fernando } \\
\text { González Bernáldez. Madrid. } \\
\text { Pascual, J. A. 2007. La gestión del uso público en espacios naturales. } \\
\text { Miraguano Ediciones. Madrid. } \\
\text { Mallarach, J.M.; Germain, J.; Sabaté, X.; y Basora, X. 2008. Protegits } \\
\text { de fet o de dret? Primera avaluació del sistema d'espais naturals } \\
\text { protegits de Catalunya. Institució Catalana d'Història Natural. } \\
\text { Disponible en: } \\
\text { http:/lichn.iec.cat/Avaluaci\%C3\%B3\%20d\%27espais.htm }\end{array}$ \\
\hline
\end{tabular}

\begin{tabular}{|c|c|}
\hline Category & Management \\
\hline Type & Response \\
\hline Description & $\begin{array}{l}\text { This indicator assesses the existence of programs and/or activities on } \\
\text { environmental education and environmental volunteering in the protected } \\
\text { area, and their regularity }\end{array}$ \\
\hline Rationale & $\begin{array}{l}\text { Environmental education and volunteering in protected areas are very } \\
\text { efficient activities to increase public environmental awareness and to } \\
\text { promote social kwoledge and valuation of the protected areas and their } \\
\text { resources (Pullin, 2002). It is one of the minimum international standards } \\
\text { for individual protected areas (Carabias et al., 2004) }\end{array}$ \\
\hline \multicolumn{2}{|r|}{ ( } \\
\hline \multicolumn{2}{|l|}{ Data availability } \\
\hline Updating & Annually \\
\hline Scale & Ordinal scale, from 0 to 2 \\
\hline $\begin{array}{l}\text { Calculation and } \\
\text { interpretation }\end{array}$ & $\begin{array}{l}\text { The indicator will be calculated as follows: } \\
\text { Regarding environmental education }(\mathrm{EE}) \text { : } \\
\text { - If regular* } \mathrm{EE} \text { activities included in a plan or program are } \\
\text { performed } \rightarrow 1.5 \text { points } \\
\text { - If sporadic } \mathrm{EE} \text { activities not included in a plan or program are } \\
\text { performed } \rightarrow 0.5 \text { points } \\
\text { - If no EE activities are performed } \rightarrow 0 \text { points } \\
\text { Regarding environmental volunteering }(\mathrm{EV}) \text { : } \\
\text { - If regular* EV activities included in a plan or program are }\end{array}$ \\
\hline
\end{tabular}




\begin{tabular}{|l|l|}
\hline & $\begin{array}{l}\text { performed } \rightarrow 0.5 \text { points } \\
\text { If sporadic EV activities not included in a plan or program are } \\
\text { performed } \rightarrow 0.3 \text { points }\end{array}$ \\
If no EV activities are performed $\rightarrow 0$ points \\
The total value of the indicator will be the simple addition (X) of the \\
values out of both variables (EE + EV). Thus, the existence of \\
environmental education and volunteering activities will be considerd \\
and valuated as follows: \\
- Adequate: $1.5 \leq \mathrm{X} \leq 2$ points $\rightarrow 2$ points \\
Moderate: $0.5 \leq \mathrm{X}<1.5$ points $\rightarrow 1$ point \\
Deficient: X $<0.5$ points $\rightarrow 0$ points
\end{tabular}

\begin{tabular}{|l|l|}
\hline 3.11. Sanctioning procedures \\
\hline Category & Management \\
\hline Type & Response \\
\hline Description & $\begin{array}{l}\text { This indicator assesses, for a precise year, the number of the sanctioning } \\
\text { procedures started against offences affecting the protected area, according } \\
\text { to their seriousness, the zone where they take place, and the type of } \\
\text { activity leading to the offence }\end{array}$ \\
\hline Rationale & $\begin{array}{l}\text { The number and seriousness of the sanctioning procedures initiated in a } \\
\text { protected area may indicate the degree of aggression by the protected area } \\
\text { or the efficiency in its prevention. Aplied to management, this indicator } \\
\text { reflects this second approach (Múgica y Gómez-Limón, 2002). }\end{array}$ \\
\hline Data source & \\
\hline Data availability & Annually \\
\hline Updating & Ordinal scale, from 0 to 2 \\
\hline Scale &
\end{tabular}




\begin{tabular}{|c|c|}
\hline $\begin{array}{l}\text { Calculation and } \\
\text { interpretation }\end{array}$ & $\begin{array}{l}\text { To valuate the indicator, the number of sanctioning procedures, their } \\
\text { seriousness, the zone where they occur (if the protected area is zoned), } \\
\text { and the activities sanctioned will be assessed. } \\
\text { The number of sanctioning procedures initiated }(\mathrm{N}) \text { will be considered } \\
\text { and valuated as follows: } \\
\text { - High: } \mathrm{N} \geq 5 / 1,000 \text { ha. } \mathrm{x} \text { year } \rightarrow 0 \text { points. } \\
\text { - Medium: } 2 \leq \mathrm{N}<5 / 1,000 \text { ha. } \mathrm{x} \text { year } \rightarrow 1 \text { point } \\
\text { - Low: } 0 \leq \mathrm{N}<2 / 1,000 \text { ha. } \mathrm{x} \text { year } \rightarrow 2 \text { points } \\
\text { 0.25 points will be subtracted from the value of } \mathrm{N} \text { for every very serious } \\
\text { procedure initiated in the core zone, independent of the area affected, } \\
\text { related to any of the following activities: } \\
\text {-Construction, } \\
\text {-Fires, } \\
\text {-Solid waste dumping or liquid waste spilling, } \\
\text {-Alien invasive species release, } \\
\text { The final value of the indicator cannot be less than } 0 \text { points. } \\
0.125 \text { points will be subtracted from the value of } \mathrm{N} \text { for every serious } \\
\text { procedure initiated in the core zone, independent of the area affected, } \\
\text { related to the previously mentioned activities. } \\
\text { These calculations will also be made for any serious or very serious } \\
\text { procedure initiated in non-zoned protected areas. } \\
\text { Thus, the sanctioning procedures occurring in the protected area will be } \\
\text { considered and valuated as follows: } \\
\text { - Few: } \mathrm{N} \geq 1.875 \rightarrow 2 \text { points } \\
\text { - Mer protected areas smaller than } 1,000 \text { ha., the valuation intervals of the } \\
\text { number of procedures will be the same, independent of the area of the } \\
\text { protected areas }\end{array}$ \\
\hline Tendency & $\begin{array}{l}\text { The tendency will be positive if } \mathrm{N} \text { is higher than in the previous } \\
\text { assessment, stable if } \mathrm{N} \text { is the same in both assessments, and negative if } \mathrm{N} \\
\text { is lower than its previous value }\end{array}$ \\
\hline References & $\begin{array}{l}\text { - Múgica, M. y Gómez-Limón, J. (Coords.). 2002. Plan de Acción para } \\
\text { los espacios naturales protegidos del Estado español. Fundación } \\
\text { Fernando González Bernáldez. Madrid. } \\
\text { Mallarach, J.M.; Germain, J.; Sabaté, X.; y Basora, X. 2008. Protegits } \\
\text { de fet o de dret? Primera avaluació del sistema d'espais naturals } \\
\text { protegits de Catalunya. Institució Catalana d'Història Natural. } \\
\text { Disponible } \\
\text { http://ichn.iec.cat/Avaluaci\%C3\%B3\%20d\%27espais.htm }\end{array}$ \\
\hline
\end{tabular}

\subsection{Monitoring}

\begin{tabular}{|l|l|}
\hline Category & Management \\
\hline Type & Response \\
\hline
\end{tabular}




\begin{tabular}{|c|c|}
\hline Description & $\begin{array}{l}\text { This indicator assesses if there is some monitoring activity regularly } \\
\text { performed on the whole protected area, on its resources or on its threats }\end{array}$ \\
\hline Rationale & $\begin{array}{l}\text { Monitoring activities allow knowing the continuous evolution of the } \\
\text { condition of the resources of a protected area and the impact of } \\
\text { management activities on those resources (Atauri et al., 2002). It is also } \\
\text { one of the minimum international standards for individual protected areas } \\
\text { (Carabias et al., 2004). It allows, on the one hand, improving the } \\
\text { knowledge of the studied features and their temporal evolution. On the } \\
\text { other, results from monitoring activities provide basic relevant } \\
\text { information for the correct, adaptable and efficient planning and } \\
\text { management of protected areas (Atauri et al., 2002; Múgica y Gómez- } \\
\text { Limón, 2002; Pullin, 2002) }\end{array}$ \\
\hline \multicolumn{2}{|r|}{ 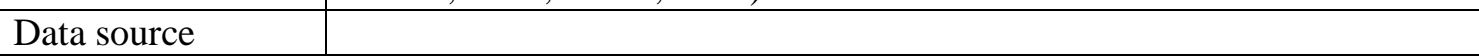 } \\
\hline \multicolumn{2}{|l|}{ Data availability } \\
\hline Updating & Annually \\
\hline Scale & Ordinal scale, from 0 to 2 \\
\hline $\begin{array}{ll}\text { Calculation } & \text { and } \\
\text { interpretation } & \end{array}$ & $\begin{array}{l}\text { The monitoring will be considered and valuated as follows: } \\
\text { - Adequate: There exist monitoring activities* on the whole } \\
\text { protected area or, at least, on the features for which the protected } \\
\text { area was designated, on the features with a special conservation } \\
\text { value and endangered, and on their main pressures and threats } \rightarrow \\
2 \text { points } \\
\text { - Moderate: There are monitoring activities on, at least, one } \\
\text { conservation feature** of the protected area } \rightarrow 1 \text { point } \\
\text { - Deficient: No monitoring activities on the protected area, its } \\
\text { resources, pressures or threats exist } \rightarrow 0 \text { points }\end{array}$ \\
\hline & $\begin{array}{l}\text { Explanatory note } \\
\text { *It is considered "monitoring activity" the studies or analyses made to the } \\
\text { same feature with regularity not longer than } 2 \text { years. } \\
\text { **It is considered "conservation feature" the whole protected area, its } \\
\text { constituent features (species, habitats, land, cultural features, etc.), or any } \\
\text { threat to any of those features or to the whole protected area. }\end{array}$ \\
\hline Tendency & $\begin{array}{l}\text { The tendency will be positive if the value of the indicator is higher than in } \\
\text { the previous assessment, stable if it is the same in both assessments, and } \\
\text { negative if the most recent value of the indicator is lower than the } \\
\text { previous one }\end{array}$ \\
\hline References & $\begin{array}{l}\text { - Atauri, J.A.; de Lucio. J.V. y Castell, C. 2002. El papel de los } \\
\text { indicadores en la gestión de los espacios naturales protegidos. En } \\
\text { Ramírez, L. (Coord.). Indicadores ambientales. Situación actual y } \\
\text { perspectivas. Organismo Autónomo Parques Nacionales. Madrid. } \\
\text { Múgica, M. y Gómez-Limón, J. (Coords.). 2002. Plan de Acción para } \\
\text { los espacios naturales protegidos del Estado español. Fundación } \\
\text { Fernando González Bernáldez. Soto del Real, Madrid. } \\
\text { - Pullin, A. 2002. Conservation Biology. Cambridge University Press. } \\
\text { Cambridge, UK. } \\
\text { - Carabias, J.; Boness, M.; De la Maza, J.; and Cadena, R. 2004. Buiding } \\
\text { capacity to manage protected areas in an era of global change. In } \\
\text { Barber, C.V.; Miller, K.R.; and Bones, M. (Eds.). Securing Protected } \\
\text { Areas in the Face of Global Change: Issues and Strategies. IUCN. } \\
\text { Gland, Switzerland and Cambridge, UK. }\end{array}$ \\
\hline
\end{tabular}

\section{Social and economic context: five indicators}




\begin{tabular}{|c|c|}
\hline \multicolumn{2}{|c|}{ 4.1. Number of municipalities in the protected area } \\
\hline Category & Social and economic context \\
\hline Type & Pressure \\
\hline Description & $\begin{array}{l}\text { This indicator assesses the number of municipalities which are totally or } \\
\text { partially included in the protected area }\end{array}$ \\
\hline Rationale & $\begin{array}{l}\text { The empirical evidence suggests that the smaller the number of } \\
\text { municipalities included in a protected area, the easier its management and } \\
\text { conservation will be due to the fewer number of actors and interests } \\
\text { involved which leads to the limitation of its pressures and threats } \\
\text { (Rodríguez-Rodríguez, 2008; VVAA, 2008) }\end{array}$ \\
\hline \multicolumn{2}{|r|}{ 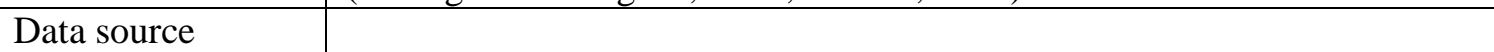 } \\
\hline \multicolumn{2}{|l|}{ Data availability } \\
\hline Updating & Every four years \\
\hline Scale & Ordinal scale, from 0 to 2 \\
\hline $\begin{array}{l}\text { Calculation and } \\
\text { interpretation }\end{array}$ & $\begin{array}{l}\text { The total number of municipalities included in the PA will be added } \\
\text { (X). It will be considered and valuated as follows: } \\
\text { - Adequate: } X=1 \rightarrow 2 \text { points } \\
\text { - Moderate: } 2 \leq X \leq 5 \rightarrow 1 \text { point } \\
\text { - Deficient: } X>5 \rightarrow 0 \text { points }\end{array}$ \\
\hline Tendency & $\begin{array}{l}\text { The tendency will be positive if } \mathrm{X} \text { is higher than in the previous } \\
\text { assessment, stable if } \mathrm{X} \text { is the same in both assessments, and negative, if } \mathrm{X} \\
\text { is lower than its previous value }\end{array}$ \\
\hline References & $\begin{array}{l}\text { - Rodríguez-Rodríguez, D. 2008. Los espacios naturales protegidos de la } \\
\text { Comunidad de Madrid. Principales amenazas para su conservación. } \\
\text { Editorial Complutense. Madrid. E-Book. Disponible en: } \\
\text { http://www.ucm.es/BUCM/ecsa/36254.php?id=187 } \\
\text { 07/04/2011]. } \\
\text { VVAA. 2008. Primer Informe de Situación de la Red de Parques } \\
\text { Nacionales a } 1 \text { de enero de 2007. Organismo Autónomo Parques } \\
\text { Nacionales. Ministerio de Medio Ambiente. Disponible en: } \\
\text { http://reddeparquesnacionales.mma.es/parques/org_auto/informacion_ge } \\
\text { neral/red_informe.htm }\end{array}$ \\
\hline
\end{tabular}

\begin{tabular}{|l|l|}
\hline 4.2. Area provided for the protected area by municipalities under local Agenda 21 \\
\hline Category & Social and economic framework \\
\hline Type & Response \\
\hline Description & $\begin{array}{l}\text { This indicator assesses the area provided to the protected area by } \\
\text { municipalities with local Agenda } 21 \text { established* }\end{array}$ \\
\hline Rationale & $\begin{array}{l}\text { The ultimate goal of Agenda } 21 \text { is achieving sustainable development at } \\
\text { local level (Martinez-Vega } \text { et al., } 2009) \text {. Therefore, it is assumed that the } \\
\text { bigger the area inside a protected area where the principles of } \\
\text { sustainability of Agenda } 21 \text { are applied in a planned manner, the easier its } \\
\text { management and conservation will be as a result of a reduction of its } \\
\text { pressures and threats }\end{array}$ \\
\hline Data source & \\
\hline Data availability & Every two years \\
\hline Updating & Ordinal scale, from 0 to 2 \\
\hline Scale & The total area provided for the protected by municipalities under local \\
\hline Calculation
\end{tabular}




\begin{tabular}{|c|c|}
\hline interpretation & $\begin{array}{l}\text { Agenda } 21 \text { established will be added }(\mathrm{X}) \text {. It will be considered and } \\
\text { valuated as follows: } \\
\text { - Adequate: If } \mathrm{X} \geq 75 \% \text { of the total area of the protected area } \rightarrow \\
2 \text { points } \\
\text { - Moderate: If } 40 \% \leq \mathrm{X}<75 \% \text { of the total area of the protected } \\
\text { area } \rightarrow 1 \text { point } \\
\text { - Deficient: If } X<40 \% \text { of the total area of the protected area } \rightarrow 0 \\
\text { points } \\
\text { Explanatory note } \\
\text { *It is considered "municipality with a local Agenda } 21 \text { established" the } \\
\text { municipality which has, at least, an action plan legally approved }\end{array}$ \\
\hline Tendency & $\begin{array}{l}\text { The tendency will be positive if } \mathrm{X} \text { is higher than in the previous } \\
\text { assessment, stable if } \mathrm{X} \text { is the same in both assessments, and negative if } \mathrm{X} \\
\text { is lower than its previous value }\end{array}$ \\
\hline References & 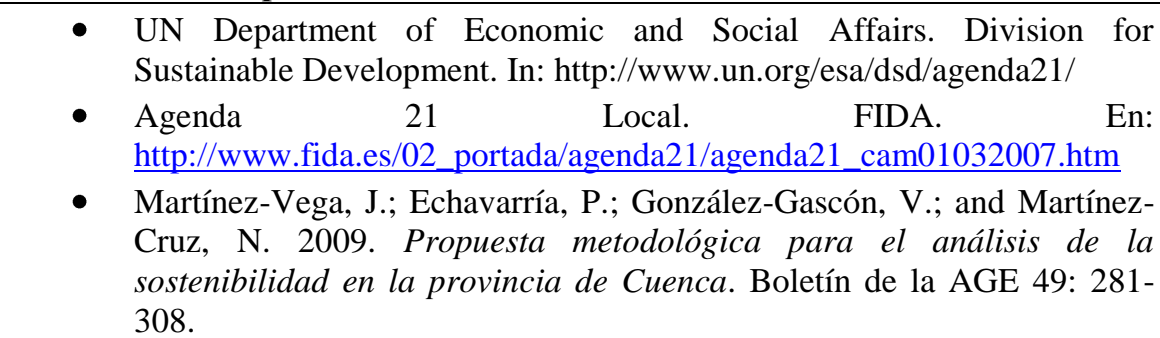 \\
\hline
\end{tabular}

\begin{tabular}{|c|c|}
\hline \multicolumn{2}{|c|}{ 4.3. Land ownership } \\
\hline Category & Social and economic framework \\
\hline Type & State \\
\hline Description & $\begin{array}{l}\text { This indicator assesses the percentage of land of the protected are owned } \\
\text { by the state, be it by public institutions, bodies or enterprises }\end{array}$ \\
\hline Rationale & $\begin{array}{l}\text { The public ownership of the land inside a protected area is considered a } \\
\text { strenght because it reduces the number of actors, interests and conflicts, } \\
\text { thus notably facilitating its management (Mulero, 2002; VVAA, 2008) }\end{array}$ \\
\hline \multicolumn{2}{|r|}{ ( } \\
\hline \multicolumn{2}{|l|}{ Data availability } \\
\hline Updating & Every four years \\
\hline Scale & Ordinal scale, from 0 to 2 \\
\hline $\begin{array}{l}\text { Calculation and } \\
\text { interpretation }\end{array}$ & $\begin{array}{l}\text { The total percentage of public land inside the protected area* }(\mathrm{X}) \text { will be } \\
\text { added. Land ownership will be considered and valuated as follows: } \\
\text { - Public: } \mathrm{X} \geq 75 \% \rightarrow 2 \text { points } \\
\text { - Semi-públic: } 40 \% \leq \mathrm{X}<75 \% \rightarrow 1 \text { point } \\
\text { - Private: } \mathrm{X}<40 \% \rightarrow 0 \text { points } \\
\text { Explanatory note } \\
\text { *All zones of the protected area will be considered. }\end{array}$ \\
\hline Tendency & $\begin{array}{l}\text { The tendency will be positive if } \mathrm{X} \text { is higher than in the previous } \\
\text { assessment, stable if } \mathrm{X} \text { is the same in both assessments, and negative if } \mathrm{X} \\
\text { is lower than its previous value }\end{array}$ \\
\hline References & $\begin{array}{l}\text { - Mulero, A. 2002. La protección de espacios naturales en España. } \\
\text { Mundi-Prensa. Madrid. } \\
\text { - Mallarach, J.M.; Germain, J.; Sabaté, X.; y Basora, X. 2008. Protegits de }\end{array}$ \\
\hline
\end{tabular}




\begin{tabular}{|l|l|}
\hline & $\begin{array}{l}\text { fet o de dret? Primera avaluació del sistema d'espais naturals protegits } \\
\text { de Catalunya. Institució Catalana d'Història Natural. Disponible en: } \\
\text { http://ichn.iec.cat/Avaluaci\%C3\%B3\%20d\%27espais.htm }\end{array}$ \\
VVAA. 2008. Primer Informe de Situación de la Red de Parques \\
Nacionales a 1 de enero de 2007. Organismo Autónomo Parques \\
Nacionales. Ministerio de Medio Ambiente. Disponible en: \\
http://reddeparquesnacionales.mma.es/parques/org auto/informacion_ge \\
neral/red informe.htm
\end{tabular}

\begin{tabular}{|c|c|}
\hline \multicolumn{2}{|c|}{ 4.4. Main economic activities in the protected area } \\
\hline Category & Social and economic context \\
\hline Type & Pressure \\
\hline Description & A meaningful form of describing this indicator was not found \\
\hline Rationale & $\begin{array}{l}\text { The state of conservation of a protected area may depend on the } \\
\text { sustainability of the economic activities performed inside it or in its } \\
\text { surroundings (VVAA, 2008) }\end{array}$ \\
\hline \multicolumn{2}{|r|}{ 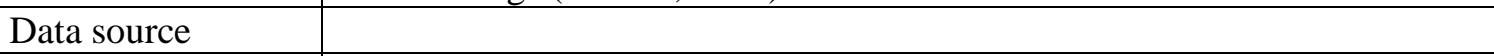 } \\
\hline \multicolumn{2}{|l|}{ Data availability } \\
\hline \multicolumn{2}{|l|}{ Updating } \\
\hline \multicolumn{2}{|l|}{ Scale } \\
\hline $\begin{array}{l}\text { Calculation and } \\
\text { interpretation }\end{array}$ & $\begin{array}{l}\text { A meaningful form of measuring and interpreting this indicator was not } \\
\text { found }\end{array}$ \\
\hline \multicolumn{2}{|r|}{ C } \\
\hline References & $\begin{array}{l}\text { - Mallarach, J.M.; Germain, J.; Sabaté, X.; y Basora, X. 2008. Protegits de } \\
\text { fet o de dret? Primera avaluació del sistema d'espais naturals protegits } \\
\text { de Catalunya. Institució Catalana d'Història Natural. Disponible en: } \\
\text { http://ichn.iec.cat/Avaluaci\%C3\%B3\%20d\%27espais.htm } \\
\text { - VVAA. 2008. Primer Informe de Situación de la Red de Parques } \\
\text { Nacionales a l de enero de 2007. Organismo Autónomo Parques } \\
\text { Nacionales. Ministerio de Medio Ambiente. Disponible en: } \\
\text { http://reddeparquesnacionales.mma.es/parques/org_auto/informacion_ge } \\
\text { neral/red_informe.htm }\end{array}$ \\
\hline
\end{tabular}

Even though a meaningful form of describing and measuring this indicator has not been found, this indicator is kept in the SIAPA due to its relevance as a way to promote its future development.

\begin{tabular}{|l|l|}
\hline 4.5. Land use changes \\
\hline Category & Social and economic context \\
\hline Type & Pressure \\
\hline Description & $\begin{array}{l}\text { This indicator assesses the changes in land uses inside and in the } \\
\text { surroundings of the protected area (1 km perimeter) since the designation } \\
\text { of the protected area or the first available data }\end{array}$ \\
\hline Rationale & $\begin{array}{l}\text { Human-made land transformation towards artificial uses and the tendency } \\
\text { towards natural afforestation in industrialized countries determine, among } \\
\text { other biogeochemical fluxes, the tendencies of biodiversity (Fernández- } \\
\text { González, 2002). The impacts of theses transformations on protected } \\
\text { areas and their resources make it advisable to analyze the land use } \\
\text { changes which have occurred inside and near protected areas } \\
\text { (Spellerberg, 1994; Radeloff et al., 2010) }\end{array}$ \\
\hline
\end{tabular}




\begin{tabular}{|c|c|}
\hline Data source & CORINE-Landcover \\
\hline Data availability & \\
\hline Updating & Every five years \\
\hline Scale & Ordinal scale, from 0 to 2 \\
\hline $\begin{array}{l}\text { Calculation and } \\
\text { interpretation }\end{array}$ & 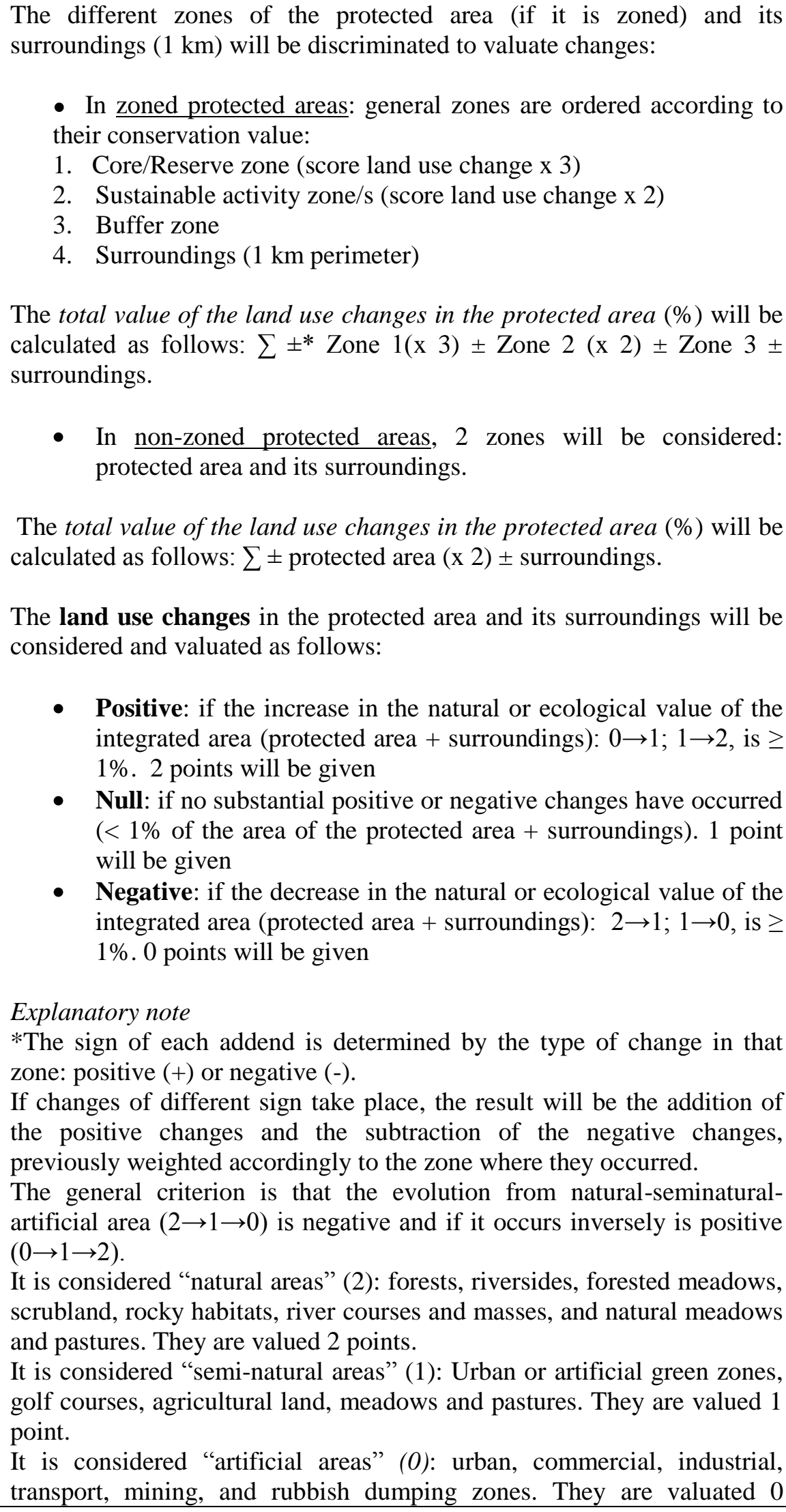 \\
\hline
\end{tabular}




\begin{tabular}{|c|c|}
\hline & points. \\
\hline Tendency & $\begin{array}{l}\text { The tendency will be considered positive, if the total value of the land use } \\
\text { changes is greater than in the previous assessment. The tendency will be } \\
\text { stable if that value is the same, and it will be negative if that value if } \\
\text { smaller than in the previous assessment }\end{array}$ \\
\hline References & $\begin{array}{l}\text { - Instituto Geográfico Nacional. Coberturas y Usos del Suelo. Corine } \\
\text { Land Cover. Nomenclatura del CORINE LAND COVER al nivel 5 } \\
\text { (CLC2000). En: http://www.ign.es/ign/layoutIn/coberturaUsoSuelo.do } \\
\text { - Spellerberg, I.F. 1994. Evaluation and Assessment for Conservation. } \\
\text { Chapman \& Hall, London. } \\
\text { - Fernández-González, F. 2002. Indicadores de biodiversidad. El estado } \\
\text { actual de la investigación. En Ramírez, L. (Coord.). Indicadores } \\
\text { ambientales. Situación actual y perspectivas. Organismo Autónomo } \\
\text { Parques Nacionales. Madrid. } \\
\text { Mallarach, J.M.; Germain, J.; Sabaté, X.; y Basora, X. 2008. Protegits } \\
\text { de fet o de dret? Primera avaluació del sistema d'espais naturals } \\
\text { protegits de Catalunya. Institució Catalana d'Historia Natural. } \\
\text { Disponible } \\
\text { http://ichn.iec.cat/Avaluaci\%C3\%B3\%20d\%27espais.htm } \\
\text { Radeloff, V.C., Stewart, S.I., Hawbaker, T.J., Gimmi, U., Pidgeon, } \\
\text { A.M., Flather, C.H., Hammer, R.B., and Helmers, D.P., 2010. Housing } \\
\text { growth in and near United States protected areas limits their } \\
\text { conservation value. PNAS, 107: 940-945. } \\
\text { Rodríguez-Rodrí́nez, 2012. Integrated networks. A territorial planning } \\
\text { proposal for long-term biodiversity conservation in urban, densely- } \\
\text { populated regions. The case of the Autonomous Region of Madrid, } \\
\text { Spain. Journal of Environmental Planning and Management, 55: 667- } \\
\text { 683 }\end{array}$ \\
\hline
\end{tabular}

\section{Social perception and valuation: four indicators}

\begin{tabular}{|c|c|}
\hline \multicolumn{2}{|c|}{ 5.1. Degree of knwoledge on the protected area } \\
\hline Category & Social perception and valuation \\
\hline Type & State \\
\hline Description & $\begin{array}{l}\text { This indicator assesses the degree of knowledge on the protected area by } \\
\text { local populations directly affected by its designation }\end{array}$ \\
\hline Rationale & $\begin{array}{l}\text { The degree of knowledge on protected areas by local populations has a } \\
\text { positive effect on their valuation, making their management easier } \\
\text { (Borrini-Feyerabend et al., 2004). The degree of knowledge on protected } \\
\text { areas allows also estimating the efficiency of the information and } \\
\text { communication measures by protected area managers }\end{array}$ \\
\hline Data source & Survey among residents \\
\hline \multicolumn{2}{|l|}{ Data availability } \\
\hline Updating & Every five years \\
\hline Scale & Ordinal scale, from 0 to 2 \\
\hline $\begin{array}{l}\text { Calculation and } \\
\text { interpretation }\end{array}$ & $\begin{array}{l}\text { A random, sistematic phone survey using the phone directory will be } \\
\text { done to a sample of } 30 \text { residents who know the protected area X, and who } \\
\text { live in the municipality(ies) included in the protected area X. If there are } \\
\text { numerous municipalities included in the protected area, the sample of } \\
\text { residents will be chosen accordingly to the population of a maximum of } \\
\text { the three bigger municipalities included in the protected area. }\end{array}$ \\
\hline
\end{tabular}




\begin{tabular}{|c|c|}
\hline & $\begin{array}{l}\text { They will be asked if they know the protected area } X \text { (full name), be it } \\
\text { physically (because they have visited it), be it culturally (because they } \\
\text { know it exists, and are able to place its limits approximately). } \\
\text { The degree of knowledge on the protected area will be considered and } \\
\text { valuated accordingly to the percentage of positive responses over the total } \\
\text { number of responses (Y) as it follows: } \\
\text { - High: } \mathrm{Y} \geq 75 \% \rightarrow 2 \text { points } \\
\text { - Moderate: } 75 \%>\mathrm{Y} \geq 50 \% \rightarrow 1 \text { point } \\
\text { - Low: } \mathrm{Y}<50 \% \rightarrow 0 \text { points }\end{array}$ \\
\hline Tendency & $\begin{array}{l}\text { The tendency will be positive if } \mathrm{Y} \text { is higher than in the previous } \\
\text { assessment, stable if } \mathrm{Y} \text { is the same in both assessments, and negative if } \mathrm{Y} \\
\text { is lower than its previous value }\end{array}$ \\
\hline References & $\begin{array}{l}\text { - Borrini-Feyerabend, G.; Kothary, A.; and Oviedo, G. (2004) Indigenous } \\
\text { and Local Communnities and Protected Areas: Towards Equity and } \\
\text { Enhanced Conservation. Gland, Switzerland and Cambridge, UK: IUCN. } \\
\text { - Rodríguez-Rodríguez, D. 2009. Mitigación de los impactos del turismo } \\
\text { en espacios naturales protegidos y mejora de su financiación a través de } \\
\text { medidas económicas. El caso de la Comunidad de Madrid. Boletín de la } \\
\text { AGE, 50: } 217-238 \text {. } \\
\text { - Rodríguez-Rodríguez, D. 2012. Perception, use and valuation of } \\
\text { protected areas by local populations in an economic crisis context. } \\
\text { Environmental Conservation, 39: 162-171. }\end{array}$ \\
\hline
\end{tabular}

\begin{tabular}{|c|c|}
\hline \multicolumn{2}{|c|}{ 5.2. Perception of the conservation state } \\
\hline Category & Social perception and valuation \\
\hline Type & State \\
\hline Description & $\begin{array}{l}\text { This indicator assesses the perception of the conservation state of the } \\
\text { protected area by local populations directly affected by its designation }\end{array}$ \\
\hline Rationale & $\begin{array}{l}\text { The perception of the conservation state of a protected area by local } \\
\text { populations reflects the perceived deviation with regard to the desired } \\
\text { conservation state. It also reflects, indirectly, the perception on its } \\
\text { management (Corraliza et al., 2002). }\end{array}$ \\
\hline Data source & Survey to residents \\
\hline Data availability & \\
\hline Updating & Every five years \\
\hline Scale & Ordinal scale, from 0 to 2 \\
\hline $\begin{array}{l}\text { Calculation and } \\
\text { interpretation }\end{array}$ & $\begin{array}{l}\text { A random, sistematic phone survey using the phone directory will be } \\
\text { done to a sample of } 30 \text { residents who know the protected area X, and who } \\
\text { live in the municipality(ies) included in the protected area X. If there are } \\
\text { numerous municipalities included in the protected area, the sample of } \\
\text { residents will be chosen accordingly to the population of a maximum of } \\
\text { the three bigger municipalities included in the protected area. } \\
\text { They will be asked how they perceive the conservation state of the } \\
\text { protected area X (full name). The following options will be given: Very } \\
\text { well conserved; Well conserved; Moderately well conserved; Not very } \\
\text { well conserved; or Poorly conserved. } \\
\text { The perception on the conservation state will be calculated by adding } \\
\text { the percentages of the responses correspondent to the categories "Very } \\
\text { well conserved" and "Well conserved" over the total number of responses }\end{array}$ \\
\hline
\end{tabular}




\begin{tabular}{|c|c|}
\hline & $\begin{array}{l}\text { (Y). It will be considered and valuated as follows: } \\
\text { - Good: } \mathrm{Y} \geq 75 \% \rightarrow 2 \text { points } \\
\text { - Moderate: } 75>\mathrm{Y} \geq 50 \% \rightarrow 1 \text { point } \\
\text { - Poor: } \mathrm{Y}<50 \% \rightarrow 0 \text { points } \\
\text { Explanatory note } \\
\text { If it has been a long time since the respondent last visited the PA (over } 3 \\
\text { years), the response will not be taken into account for the calculation of } \\
\text { the indicator. }\end{array}$ \\
\hline Tendency & $\begin{array}{l}\text { The tendency will be positive if } \mathrm{Y} \text { is higher than in the previous } \\
\text { assessment, stable if } \mathrm{Y} \text { is the same in both assessments, and negative if } \mathrm{Y} \\
\text { is lower than its previous value }\end{array}$ \\
\hline References & $\begin{array}{l}\text { - Corraliza, J.A.; Martín, R.; Berenguer, J.; y Moreno, M. 2002. Los } \\
\text { espacios naturales protegidos, escenarios de intervención psicosocial. } \\
\text { Intervención Psicosocial 11: 303-316. } \\
\text { - Mallarach, J.M.; Germain, J.; Sabaté, X.; y Basora, X. 2008. Protegits } \\
\text { de fet o de dret? Primera avaluació del sistema d'espais naturals protegits de } \\
\text { Catalunya. Institució Catalana d'Història Natural. Disponible en: } \\
\text { http://ichn.iec.cat/Avaluaci\%C3\%B3\%20d\%27espais.htm } \\
\text { - Rodríguez-Rodríguez, D. 2012. Perception, use and valuation of } \\
\text { protected areas by local populations in an economic crisis context. } \\
\text { Environmental Conservation, 39: } 162-171 \text {. }\end{array}$ \\
\hline
\end{tabular}

\begin{tabular}{|c|c|}
\hline \multicolumn{2}{|c|}{ 5.3. Personal importance } \\
\hline Category & Social perception and valuation \\
\hline Type & State \\
\hline Description & $\begin{array}{l}\text { This indicator assesses the importance given by residents to nearby } \\
\text { protected areas }\end{array}$ \\
\hline Rationale & $\begin{array}{l}\text { The bigger the importance given by local populations to protected areas, } \\
\text { the more positive attitude and behaviour towards them those populations } \\
\text { will have, thus facilitating management (Pomeroy et al., 2005). }\end{array}$ \\
\hline Data source & Survey to residents \\
\hline Data availability & \\
\hline Updating & Every five years \\
\hline Scale & Ordinal scale, from 0 to 2 \\
\hline $\begin{array}{l}\text { Calculation and } \\
\text { interpretation }\end{array}$ & $\begin{array}{l}\text { A random, sistematic phone survey using the phone directory will be } \\
\text { done to a sample of } 30 \text { residents who know the protected area X, and who } \\
\text { live in the municipality(ies) included in the protected area X. If there are } \\
\text { numerous municipalities included in the protected area, the sample of } \\
\text { residents will be chosen accordingly to the population of a maximum of } \\
\text { the three bigger municipalities included in the protected area. } \\
\text { They will be asked how important the PA X (full name) is for them. The } \\
\text { following options will be given: Very important; Important; Not very } \\
\text { important; or Unimportant. } \\
\text { The personal importance will be calculated by adding the percentages } \\
\text { of responses corresponding to the categories "Very important" and } \\
\text { "Important" over the total number of responses (Y). It will be considered } \\
\text { and valuated as follows. } \\
\text { - High: } Y \geq 75 \% \rightarrow 2 \text { points }\end{array}$ \\
\hline
\end{tabular}




\begin{tabular}{|l|l|}
\hline & $\begin{array}{l}\text { Moderate: } 75>\mathrm{Y} \geq 50 \% \rightarrow 1 \text { point } \\
\text { - Low: } \mathrm{Y}<50 \% \rightarrow 0 \text { points }\end{array}$ \\
\hline Tendency & $\begin{array}{l}\text { The tendency will be positive if } \mathrm{Y} \text { is higher than in the previous } \\
\text { assessment, stable if Y is the same in both assessments, and negative if Y } \\
\text { is lower than its previous value }\end{array}$ \\
\hline References & $\begin{array}{l}\text { doing? A methodology for evaluating the management effectiveness of marine } \\
\text { protected areas. IUCN, Gland, Switzerland, and Cambridge, United }\end{array}$ \\
& Kingdom. \\
& Rodríguez-Rodríguez, D. 2012. Perception, use and valuation of \\
protected areas by local populations in an economic crisis context. \\
Environmental Conservation, 39: 162-171.
\end{tabular}

\begin{tabular}{|c|c|}
\hline \multicolumn{2}{|c|}{ 5.4. Economic valuation of the protected area } \\
\hline Category & Social perception and valuation \\
\hline Type & State \\
\hline Description & $\begin{array}{l}\text { This indicator assesses the opinion of local residents on } 3 \text { variables which } \\
\text { determine their economic valuation of the nearby protected area: 1) the } \\
\text { public (state) financing of the PA; 2) their willingness to pay to conserve the } \\
\text { protected area or to improve it environmentally; and 3) their willingness to } \\
\text { accept the establishment of an entrance fee to the protected area }\end{array}$ \\
\hline Rationale & $\begin{array}{l}\text { The willingness to pay (directly or indirectly) of local populations to } \\
\text { conserve or improve protected areas estimates in the most precise and } \\
\text { objective forms their valuation of these protected areas (Azqueta et al., } \\
\text { 2007). A high valuation of protected areas will determine a more positive } \\
\text { attitude and behaviour towards them }\end{array}$ \\
\hline Data source & Survey to residents \\
\hline \multicolumn{2}{|l|}{ Data availability } \\
\hline Updating & Every five years \\
\hline Scale & Ordinal scale, from 0 to 2 \\
\hline $\begin{array}{l}\text { Calculation and } \\
\text { interpretation }\end{array}$ & $\begin{array}{l}\text { A random, sistematic phone survey using the phone directory will be done } \\
\text { to a sample of } 30 \text { residents who know the protected area X, and who live in } \\
\text { the municipality(ies) included in the protected area X. If there are numerous } \\
\text { municipalities included in the protected area, the sample of residents will be } \\
\text { chosen accordingly to the population of a maximum of the three bigger } \\
\text { municipalities included in the protected area. }\end{array}$ \\
\hline
\end{tabular}

They will be asked if they agree that the public (state) administrations spend a part of their budget on the conservation of the PA $H$ (full name). The percentages of positive responses over the total $(\mathrm{X})$ will be considered and valuated as follows:

- High: $X \geq 75 \% \rightarrow 2$ points

- Moderate: $75 \%>X \geq 50 \% \rightarrow 1$ point

- Low: $\mathrm{X}<50 \% \rightarrow 0$ points

Then, they will be asked if they would be willing to pay higher taxes to conserve or improve the PA $H$ environmentally. The percentages of positive responses over the total $(\mathrm{Y})$ will be considered and valuated as follows:

- High: $\mathrm{Y} \geq 75 \% \rightarrow 2$ points

- Moderate: $75 \%>\mathrm{Y} \geq 50 \% \rightarrow 1$ point

- Low: $\mathrm{Y}<50 \% \rightarrow 0$ points

Finally, they will be asked if they would be willing to accept and entrance fee to the PA $H$. The percentages of positive responses over the total $(\mathrm{Z})$ will 


\begin{tabular}{|c|c|}
\hline & $\begin{array}{l}\text { be considered and valuated as follows: } \\
\text { - High: } \mathrm{Z} \geq 75 \% \rightarrow 2 \text { points } \\
\text { - Moderate: } 75 \%>\mathrm{Z} \geq 50 \% \rightarrow 1 \text { point } \\
\text { - Low: } \mathrm{Z}<50 \% \rightarrow 0 \text { points } \\
\text { The economic valuation of the protected area will be calculated as the } \\
\text { simple average value of the } 3 \text { variables: } \sum(\mathrm{X}+\mathrm{Y}+\mathrm{Z}) / 3 \text {. The result }(\mathrm{W}) \text { will } \\
\text { be considered and valuated as follows: } \\
\text { - High: } 1.33 \leq \mathrm{W} \leq 2 \rightarrow 2 \text { points } \\
\text { - Moderate: } 1.33>\mathrm{W} \geq 1 \rightarrow 1 \text { point } \\
\text { - Low: } \mathrm{W}<1 \rightarrow 0 \text { points }\end{array}$ \\
\hline Tendency & $\begin{array}{l}\text { The tendency will be positive if } \mathrm{W} \text { is higher than in the previous assessment, } \\
\text { stable, if } \mathrm{W} \text { is the same in both assessments, and negative if } \mathrm{W} \text { is lower than } \\
\text { its previous value }\end{array}$ \\
\hline References & $\begin{array}{l}\text { Brotherton, I. 1996. Protected Area Theory at the System Level. Journal } \\
\text { of Environmental Management, 47: 369-379. } \\
\text { - Azqueta, D.; Alviar, M.; Domínguez, L.; y O Ryan, R. 2007. Introducción } \\
\text { a la economía ambiental. Segunda edición. McGraw-Hill. Madrid. } \\
\text { - Rodríguez-Rodríguez, D. 2009. Mitigación de los impactos del turismo en } \\
\text { espacios naturales protegidos y mejora de su financiación a través de medidas } \\
\text { económicas. El caso de la Comunidad de Madrid. Boletín de la AGE, 50: 217- } \\
238 \text {. } \\
\text { - Rodríguez-Rodríguez, D. 2012. Perception, use and valuation of protected } \\
\text { areas by local populations in an economic crisis context. Environmental } \\
\text { Conservation, 39:162-171. }\end{array}$ \\
\hline
\end{tabular}

\section{Threats to conservation: nine indicators}

\begin{tabular}{|c|c|}
\hline \multicolumn{2}{|c|}{ 6.1. Presence of alien invasive species } \\
\hline Category & Threats to conservation \\
\hline Type & Pressure \\
\hline Description & $\begin{array}{l}\text { This indicator assesses the presence of alien invasive species (AIS) in the } \\
\text { protected area }\end{array}$ \\
\hline Rationale & $\begin{array}{l}\text { AIS are one of the most serious global threats to the conservation of } \\
\text { biodiversity (Pullin, 2002; Pressey et al., 2007; Chape et al., 2008). The } \\
\text { most serious impacts on native biodiversity are related to inter-specific } \\
\text { interactions such as predation, parasitism, competence for resources, } \\
\text { disease transmission, or to ecosystem`s modification (Díaz-Esteban, } \\
\text { 2002) }\end{array}$ \\
\hline \multicolumn{2}{|l|}{ Data source } \\
\hline \multicolumn{2}{|l|}{ Data availability } \\
\hline Updating & Annual \\
\hline Scale & Ordinal scale, from 0 to 2 \\
\hline $\begin{array}{l}\text { Calculation and } \\
\text { interpretation }\end{array}$ & $\begin{array}{l}\text { The presence of alien invasive species* will be considered and valuated } \\
\text { as follows: } \\
\text { - Null: There are no proved signs** of the existence of AIS in the } \\
\text { protected area } \rightarrow 0 \text { points } \\
\text { - Moderate: There are proved signs of the existence of one AIS in } \\
\text { the protected area } \rightarrow 1 \text { point } \\
\text { - High: There are proved signs of the existence of more than one } \\
\text { AIS in the protected area } \rightarrow 2 \text { points }\end{array}$ \\
\hline
\end{tabular}




\begin{tabular}{|c|c|}
\hline & $\begin{array}{l}\text { Explanatory note } \\
\text { *It will be considered "AIS" the species included in the DAISIE } \\
\text { European project as they are, by specialists consensus, the most } \\
\text { dangerous to European biodiversity. } \\
\text { **It will be considered "proved signs" the sightseeing of individuals, the } \\
\text { unmistakable discovery of marks or footprints inside the protected area, } \\
\text { and the inclusion of AIS in specialised bibliography on the protected } \\
\text { area. }\end{array}$ \\
\hline Tendency & $\begin{array}{l}\text { The tendency will be considered positive if the number of AIS is smaller } \\
\text { than in the previous assessment. The tendency will be considered stable } \\
\text { is the number of AIS is the same in both assessments, and the tendency } \\
\text { will be considered negative if the number of AIS is higher than in the } \\
\text { previous assessment }\end{array}$ \\
\hline References & $\begin{array}{l}\text { - Ley 42/2007, de } 13 \text { de diciembre, del Patrimonio Natural y de la } \\
\text { Biodiversidad. Arts., 3.13, 61, 76.f, y 77. } \\
\text { Ley } 2 / 1991, \text { de } 14 \text { de febrero, para la Protección de la Fauna y la Flora } \\
\text { Silvestres en la Comunidad de Madrid. Arts. } 1,2,22 \text { y } 45.4 . i . \\
\text { Ley 7/1990, de } 28 \text { de junio, de Protección de embalses y Zonas } \\
\text { húmedas de la Comunidad Autónoma de Madrid. Art. } 16 . \\
\text { VVAA. 1997. Plan Rector de Uso y Gestión del Parque Regional de la } \\
\text { Cuenca Alta del Manzanares. Dirección General de Educación y } \\
\text { Prevención Ambiental. Consejería de Medio Ambiente y Desarrollo } \\
\text { Regional. Comunidad de Madrid. } \\
\text { Notario, A. (Coord.). 1998. Plan Forestal de la Comunidad de Madrid. } \\
\text { Programa de Protección y Manejo de la Fauna. Tomo III. Consejería } \\
\text { de Medio Ambiente y Desarrollo Regional. Comunidad de Madrid. } \\
\text { Doc. Int. } \\
\text { VVAA. 2004. Inventario piscícola para la gestión de los cotos } \\
\text { trucheros de la Comunidad de Madrid. Servicio de Protección de Flora } \\
\text { y Fauna. Dirección General del Medio Natural. Consejería de Medio } \\
\text { Ambiente y Ordenación del Territorio. CAM. Doc. Int. } \\
\text { Delibes, M. 2001. Vida. La naturaleza en peligro. Temas de hoy. } \\
\text { Madrid. } \\
\text { Díaz-Esteban, M. 2002. Elementos y procesos clave para el } \\
\text { funcionamiento de los sistemas naturales: las Calculation and } \\
\text { interpretations con significado funcional como alternativa a los } \\
\text { indicadores clásicos. En Ramírez, L. (Coord.). Indicadores } \\
\text { ambientales. Situación actual y perspectivas. Organismo Autónomo } \\
\text { Parques Nacionales. Madrid. } \\
\text { Pullin, A. 2002. Conservation Biology. Cambridge University Press. } \\
\text { Cambridge, UK. } \\
\text { Pressey, R.L.; Cabeza, M.; Watts, M.E.; Cowling, R.M.; and Wilson, } \\
\text { K.A. 2007. Conservation planning in a changing world. Trends in } \\
\text { Ecology and Evolution } 22 \text { (11): } 583-592 . \\
\text { Chape, S.; Spalding, M.; and Jenkins; M.D. 2008. The World's } \\
\text { Protected Areas: Status, Values and Prospects in the 21st Century. } \\
\text { Prepared by the UNEP World Conservation Monitoring Centre, } \\
\text { University of California Press, Berkeley, USA. } \\
\text { DAISIE. En: http://www.europe-aliens.org/index.jsp } \\
\text { Flora Ibérica. En: http://www.floraiberica.org/ }\end{array}$ \\
\hline
\end{tabular}

6.2. Climate change

\begin{tabular}{|l|l|}
\hline Category & Threats to conservation \\
\hline Type & Pressure \\
\hline
\end{tabular}




\begin{tabular}{|c|c|}
\hline Description & $\begin{array}{l}\text { This indicator assesses the variation in temperature and precipitation in the } \\
\text { protected area as possible signs of climate change }\end{array}$ \\
\hline Rationale & $\begin{array}{l}\text { Climate change is a global threat which imposes rising direct and indirect } \\
\text { pressures on protected areas and on their management (Barber, 2004; } \\
\text { Chape et al., 2008; Nolte et al., 2010; Araújo et al., 2011). These pressures } \\
\text { are linked to unusually-rapid changes in environmental parameters crucial } \\
\text { for biodiversity to which some populations are not able to adapt leading to } \\
\text { their extinction (Pullin, 2002; Mora and Sale, 2011) }\end{array}$ \\
\hline \multicolumn{2}{|l|}{ Data source } \\
\hline \multicolumn{2}{|l|}{ Data availability } \\
\hline Updating & Every ten years \\
\hline Scale & Ordinal scale, from 0 to 2 \\
\hline $\begin{array}{l}\text { Calculation and } \\
\text { interpretation }\end{array}$ & 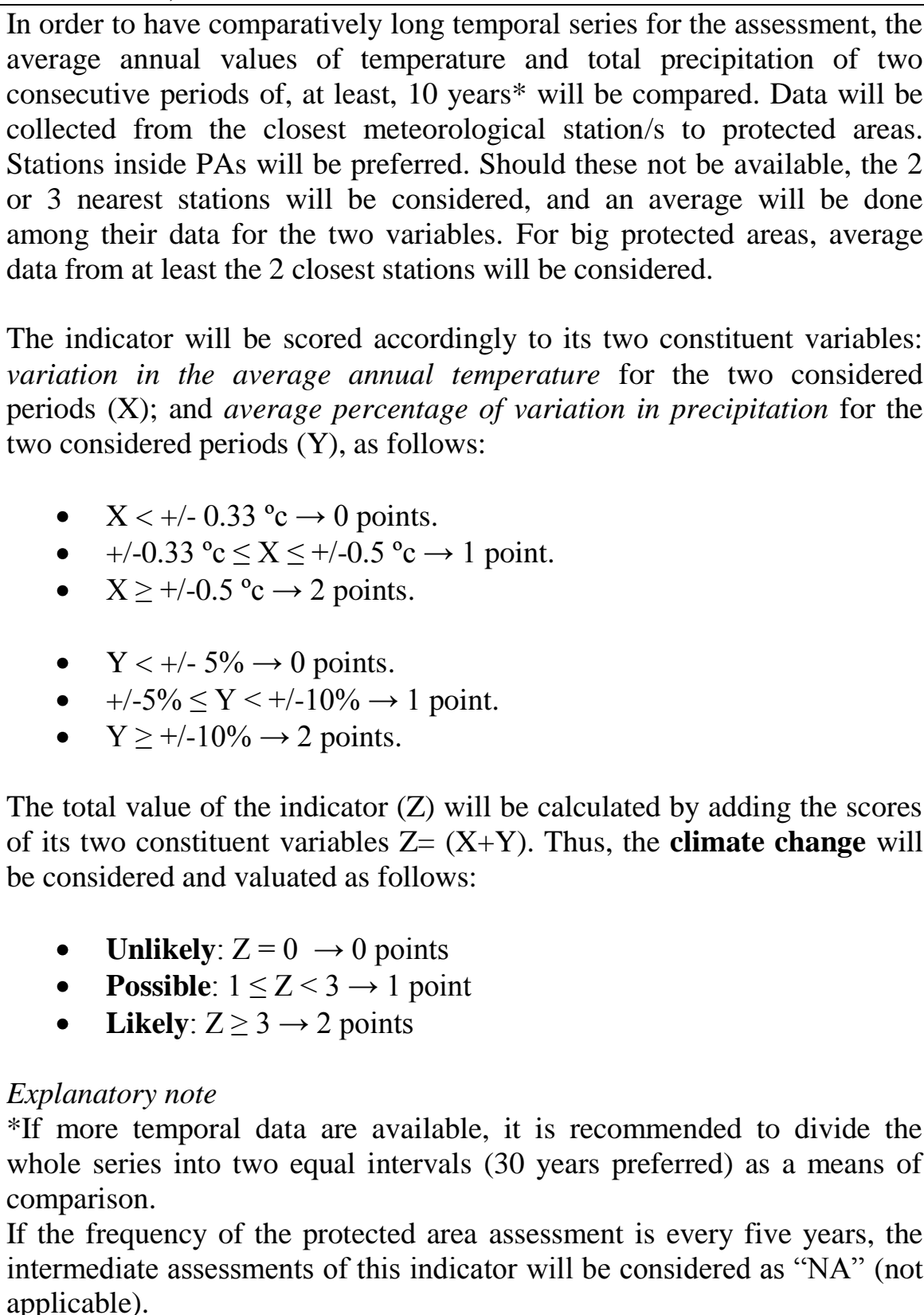 \\
\hline Tendency & $\begin{array}{l}\text { The tendency will be considered positive if } \mathrm{X} \text { and } \mathrm{Y} \text { vary in an equal or } \\
\text { inferior quantity than their lowest intervals ( } 0 \text { points) compared to the } \\
\text { previous assessment. The tendency will be considered stable if } \mathrm{X} \text { and } \mathrm{Y} \\
\text { are within the intermediate intervals in both assessment periods, or if one } \\
\text { of the variables increases its value (to an upper inteval) and the other }\end{array}$ \\
\hline
\end{tabular}




\begin{tabular}{|l|l|l|}
\hline & $\begin{array}{l}\text { variable decreases (to a lower interval). The tendency will be considered } \\
\text { negative if X and Y vary in an equal or superior quantity than their upper } \\
\text { intervals (2 points) compared to the previous assessment }\end{array}$ \\
\hline References & Montero, J.L. y González, J.L. 1974. Diagramas bioclimáticos. ICONA. \\
Madrid. & García, L. y Reija, A. 1994. Tiempo y clima en España. Meteorología de \\
& las Autonomías. Dossat-2000. Madrid. \\
- Pita, Ma. F. y Aguilar, M. (Orgs.). 1994. Cambios y variaciones \\
climáticas en España. Fundación El Monte. Sevilla. \\
Cuadrat, J.M. ; Vicente, S.M ; y Saz, M.A. (Eds.). 2002. La información \\
climática como herramienta de gestión ambiental. Bases de datos y \\
tratamiento de series climatologicas. Universidad de Zaragoza. \\
Zaragoza. \\
Pullin, A. 2002. Conservation Biology. Cambridge University Press. \\
Cambridge, UK. \\
Barber, C.V. 2004. Designing protected area systems for a changing \\
world. In Barber, C.V.; Miller, K.R.; and Bones, M. (Eds.). Securing \\
Protected Areas in the Face of Global Change: Issues and Strategies. \\
IUCN. Gland, Switzerland and Cambridge, UK. \\
Chape, S.; Spalding, M.; and Jenkins; M.D. 2008. The World's Protected \\
Areas: Status, Values and Prospects in the 21st Century. Prepared by the \\
UNEP World Conservation Monitoring Centre, University of California \\
Press, Berkeley, USA. \\
Araújo, M.B., Alagador, D., Cabeza, M., Nogués-Bravo, D. and Thuiller, \\
W., 2011. Climate change threatens European conservation areas. Ecol. \\
Lett. 14: 484-492. \\
Mora, C. and Sale, P.F. 2011. Ongoing global biodiversity loss and the \\
need to move beyond protected areas: a review of the technical and \\
practical shortcomings of protected areas on land and sea. Marine \\
Ecology Progress Series, 434: 251-266.
\end{tabular}

\begin{tabular}{|l|l|}
\hline 6.3. Area affected by fires \\
\hline Category & Threats to conservation \\
\hline Type & Pressure \\
\hline Description & $\begin{array}{l}\text { This indicator assesses the area (and the zone, if applicable) of the } \\
\text { protected area affected by fires }\end{array}$ \\
\hline Rationale & $\begin{array}{l}\text { Forest fires are a natural phenomenon in the Mediterranean region (de } \\
\text { Miguel y Díaz-Pineda, 2003; Chuvieco, 2009). However, some human } \\
\text { variables, such as the number and frequency of visits to natural areas, the } \\
\text { activities performed in these areas or the growth of the urban-forest } \\
\text { interface may lead to an increase in the frequency of forest fires (Vilar } \text { et } \\
\text { al., 2008; Chuvieco } \text { et al., 2010; Vilar } \text { et al., 2011) which may exceed the } \\
\text { ecosystems resilience and lead to important changes in their structure and } \\
\text { function. Also, fires inside protected areas are especially dangerous, due to } \\
\text { the character of these areas as refuges of threatened biodiversity, and due } \\
\text { to their limited size. As a result, fires inside protected areas may impact } \\
\text { some populations as severely as to cause their extinction }\end{array}$ \\
\hline Data source & and \\
\hline Data availability & Annually \\
\hline Updating & $\begin{array}{l}\text { Ordinal scale, from } 0 \text { to 2 } \\
\text { since the first available data will be considered and valuated as follows: }\end{array}$ \\
\hline Scale & $\begin{array}{l}\text { Calculation } \\
\text { interpretation }\end{array}$ \\
\hline
\end{tabular}




\begin{tabular}{|c|c|}
\hline & $\begin{array}{l}\text { In non-zoned protected areas: } \\
\text { - Low: if the average percentage of the protected area affected by } \\
\text { fires }(\mathrm{X}), \text { calculated as the addition of the hectares affected by } \\
\text { fires in the last two years divided by the total number of hectares } \\
\text { of the protected area (x 100), has affected an area of a maximum } \\
\text { of } 5 \% \text { of the area of the protected area } \rightarrow 0 \text { points. } \\
\text { Moderate: if } 5 \%<\mathrm{X} \leq 10 \% \text { of the total area of the protected area } \\
\rightarrow 1 \text { point. } \\
\text { High: if } \mathrm{X}>10 \% \text { of the total area of the protected area } \rightarrow 2 \\
\text { points. } \\
\text { In zoned protected areas: } \\
\text { - Low: if the average percentage of the protected area affected by } \\
\text { fires }(\mathrm{X}), \text { calculated as the addition of the hectares affected by } \\
\text { fires in the last two years divided by the total number of hectares } \\
\text { of the PA (x } 100), \text { has affected an area of a maximum of } 5 \% \text { of the } \\
\text { area of the protected area, including a maximum of } 2 \% \text { of the core } \\
\text { zone* } \rightarrow 0 \text { points. } \\
\text { Moderate: if } 5 \%<\mathrm{X} \leq 10 \% \text { of the total area of the protected area } \\
\text { or the percentage of the core zone affected by fires (Y) is: } 2 \%<\mathrm{Y} \\
\leq 5 \% \rightarrow 1 \text { point. } \\
\text { - High: if } \mathrm{X}>10 \% \text { of the total area of the protected area or } \mathrm{Y}>5 \% \\
\rightarrow 2 \text { points. } \\
\text { Explanatory note } \\
\text { *It is considered "core zone" the nuclear zone of the protected area with } \\
\text { the highest conservation value, independent of its name: core zone, reserve } \\
\text { zone, etc. } \\
\text { Y is calculated the same as } \mathrm{X}, \text { but considering only the area of the core } \\
\text { zone and of the hectares affected by fires inside it. }\end{array}$ \\
\hline Tendency & $\begin{array}{l}\text { The tendency will be considered positive if the average number of hectares } \\
\text { affected by fires in the last } 2 \text { years of the analyzed period is smaller than } \\
\text { the average number of the } 5 \text { years immediately prior to the last two years } \\
\text { analysed. The tendency will be stable if those values are equal, and it will } \\
\text { be negative if the average number of hectares affected by fires in the last } 2 \\
\text { years is higher than the average number of the } 5 \text { previous years }\end{array}$ \\
\hline References & $\begin{array}{l}\text { - Ley 43/2003, de } 21 \text { de noviembre, de Montes. Arts. 1, 2.3, 3, 4, 5, 6, } \\
\text { 7.2.i, 43, 55 y } 56 . \\
\text { De Miguel, J.M. y Díaz-Pineda, F. 2003. Medio ambiente. Problemas y } \\
\text { posibilidades. En García-Delgado, J.L. (Dir.). Estructura económica de } \\
\text { Madrid. Segunda edición. Consejería de Justicia e Innovación } \\
\text { Tecnológica. Comunidad de Madrid. Madrid. } \\
\text { - Mallarach, J.M.; Germain, J.; Sabaté, X.; y Basora, X. 2008. Protegits de } \\
\text { fet o de dret? Primera avaluació del sistema d'espais naturals protegits } \\
\text { de Catalunya. Institució Catalana d'Historia Natural. Disponible en: } \\
\text { http://ichn.iec.cat/Avaluaci\%C3\%B3\%20d\%27espais.htm } \\
\text { Vilar, L.; Martín, M.P. y Martínez Vega, J. 2008. Empleo de técnicas de } \\
\text { regresión logística para la obtención de modelos de riesgo humano de } \\
\text { incendio forestal a escala regional. Boletín de la Asociación de } \\
\text { Geógrafos Españoles, 47: 5-29. } \\
\text { Chuvieco, E. 2009. Earth Observation of Wildland Fires in } \\
\text { Mediterranean Ecosystems. Springer-Verlag. Berlin. } \\
\text { Chuvieco, E; Aguado, I; Yebra, M; Nieto, H; Salas, J; Martín, M.P; } \\
\text { Vilar, L; Martínez Vega, J; Martín, S; Ibarra, P; de la Riva, J; Baeza, J; } \\
\text { Rodríguez, F; Molina, J.R; Herrera, M.A; y Zamora, R. 2010. } \\
\text { Development of a framework for fire danger assessment using Remote }\end{array}$ \\
\hline
\end{tabular}




\begin{tabular}{|l|l|}
\hline & Sensing and Geographic Information System technologies. Ecological \\
& Modelling, 221: 46-58. \\
& Vilar, L; Martín, M.P; y Martínez Vega, J., 2011. Logistic regression \\
& models for human-caused wildfire risk estimation: analysing the effect of \\
the spatial accuracy in fire occurrence data. European Journal of Forest \\
Research, DOI: 10.1007/s10342-011-0488-2.
\end{tabular}

\begin{tabular}{|c|c|}
\hline \multicolumn{2}{|l|}{ 6.4. Fragmentation } \\
\hline Category & Threats to conservation \\
\hline Type & Pressure \\
\hline Description & $\begin{array}{l}\text { This indicator assesses the degree of fragmentation of the natural habitats } \\
\text { in the protected area }\end{array}$ \\
\hline Rationale & $\begin{array}{l}\text { Fragmentation of natural habitats is one of the main global causes of } \\
\text { biodiversity loss due to its impacts on the loss of habitats and on the loss } \\
\text { of quality of habitats (Fernández-González, 2002; Pullin, 2002; Chape et } \\
\text { al., 2008; Nolte et al., 2010) }\end{array}$ \\
\hline \multicolumn{2}{|r|}{ 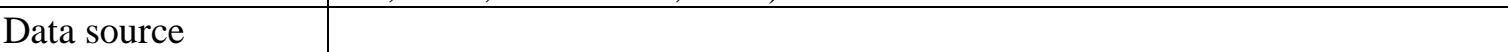 } \\
\hline \multicolumn{2}{|l|}{ Data availability } \\
\hline Updating & Every four years \\
\hline Scale & Ordinal scale, from 0 to 2 \\
\hline $\begin{array}{l}\text { Calculation and } \\
\text { interpretation }\end{array}$ & 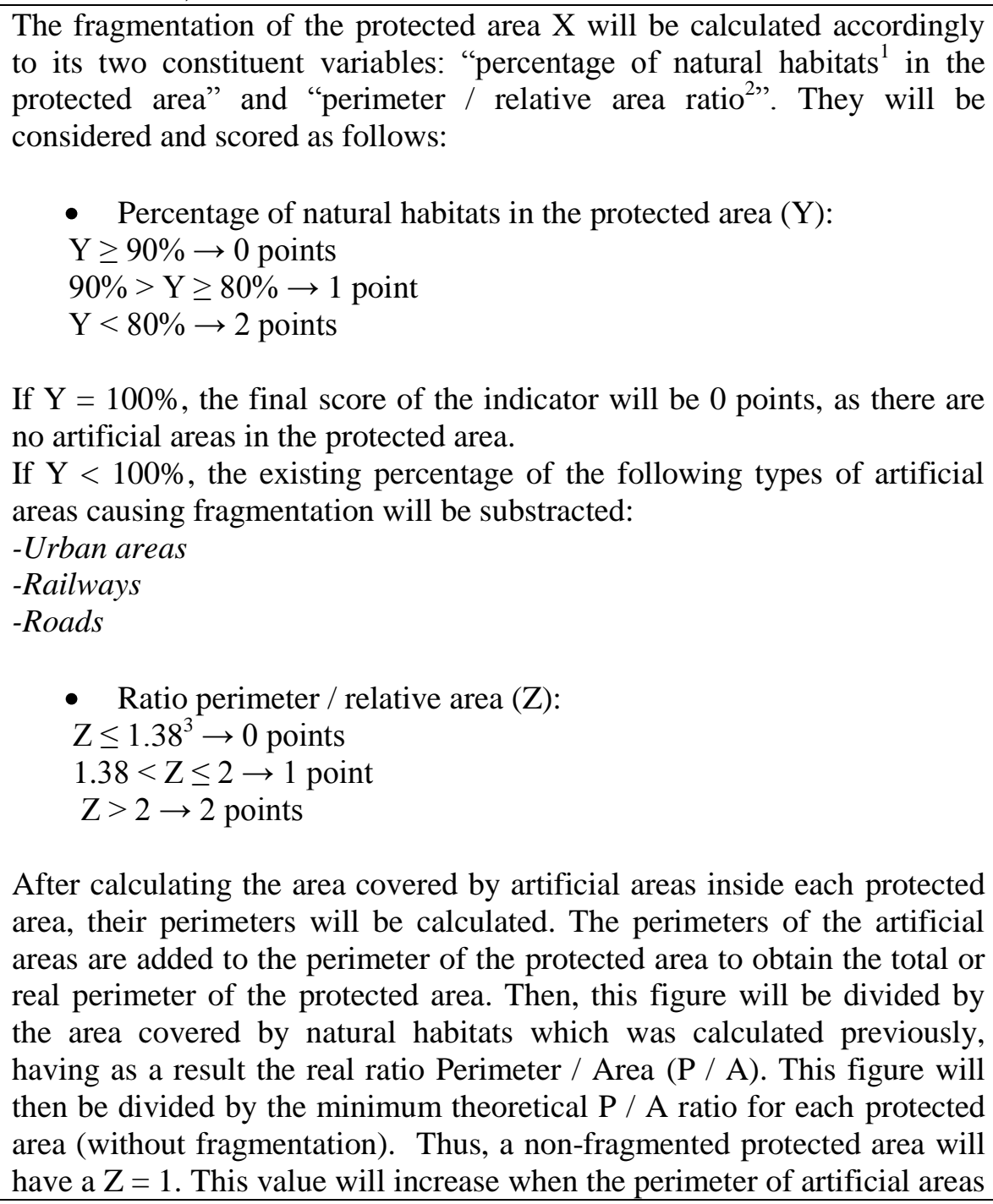 \\
\hline
\end{tabular}




\begin{tabular}{|c|c|}
\hline & $\begin{array}{l}\text { inside the protected area increase. } \\
\text { The final score of the indicator (W) will be calculated by adding both } \\
\text { scores }(\mathrm{Y}+\mathrm{Z} \text { ). Thus, the fragmentation will be considered and valuated } \\
\text { as follows: } \\
\text { - Low: } \mathrm{W}=0 \rightarrow 0 \text { points } \\
\text { - Moderate: } 1 \leq \mathrm{W} \leq 2 \rightarrow 1 \text { point } \\
\text { - High: } \mathrm{W}>2 \rightarrow 2 \text { points } \\
\text { Explanatory notes } \\
{ }^{1} \text { It is considered "natural habitats" habitats entirely natural and also semi- } \\
\text { natural habitats (Dir. } 92 / 43 / \mathrm{CEE)} \mathrm{and,} \mathrm{therefore,} \mathrm{the} \mathrm{classes} 2,3,4 \text { and } 5 \\
\text { of CORINE LandCover. } \\
{ }^{2} \text { The "perimeter / relative area ratio" is used to avoid errors in the } \\
\text { interpretation of fragmentation due to the effect of the shape of the } \\
\text { protected area. For instance, a protected area may have a high P/A and } \\
\text { have low fragmentation due to its long shape. That way, the real P / A ratio } \\
\text { is compared with the minimum possible P / A ratio according to the shape } \\
\text { of the protected area. } \\
{ }^{3} \text { The value of the median divides very little fragmented protected areas } \\
\text { from other notably fragmented protected areas. }\end{array}$ \\
\hline Tendency & $\begin{array}{l}\text { The tendency will be considered as positive if the value of } \mathrm{Y} \text { increases and } \\
\text { the value of } \mathrm{Z} \text { decreases compared to the previous assessment. The } \\
\text { tendency will be stable if both values are equal or if both variables } \\
\text { increase or decrease. It will be negative if } \mathrm{Y} \text { is smaller and } \mathrm{Z} \text { is bigger than } \\
\text { in the previous assessment }\end{array}$ \\
\hline References & $\begin{array}{l}\text { - Directiva 92/43/CEE del Consejo, de } 21 \text { de mayo de } 1992 \text {, relativa a la } \\
\text { conservación de los hábitats naturales y de la fauna y flora silvestres. Art. } \\
\text { 1.b. } \\
\text { Ley 42/2007, de } 13 \text { de diciembre, del Patrimonio Natural y de la } \\
\text { Biodiversidad. Arts. 17.g, 19.g, } 20 \text { y } 46 . \\
\text { - Fernández-González, F. 2002. Indicadores de biodiversidad. El estado } \\
\text { actual de la investigación. En Ramírez, L. (Coord.). Indicadores } \\
\text { ambientales. Situación actual y perspectivas. Organismo Autónomo } \\
\text { Parques Nacionales. Madrid. } \\
\text { - Pullin, A. 2002. Conservation Biology. Cambridge University Press. } \\
\text { Cambridge. } \\
\text { - Chape, S.; Spalding, M.; and Jenkins; M.D. 2008. The World's Protected } \\
\text { Areas: Status, Values and Prospects in the 21st Century. Prepared by the } \\
\text { UNEP World Conservation Monitoring Centre, University of California } \\
\text { Press, Berkeley, USA. } \\
\text { Mallarach, J.M.; Germain, J.; Sabaté, X.; y Basora, X. 2008. Protegits de } \\
\text { fet o de dret? Primera avaluació del sistema d'espais naturals protegits } \\
\text { de Catalunya. Institució Catalana d'Historia Natural. Disponible en: } \\
\text { http://ichn.iec.cat/Avaluaci\%C3\%B3\%20d\%27espais.htm } \\
\text { Nolte, C.; Leverington, F.; Kettner, A.; Marr, M.; Nielsen, G.; Bomhard, } \\
\text { B.; Stolton, S.; Stoll-Kleemann, S.; and Hockings, M. 2010. Protected } \\
\text { Area Management Effectiveness Assessments in Europe. A review of } \\
\text { application, methods and results. University of Greifswald. Greifswald, } \\
\text { Germany. } \\
\text { Rodríguez-Rodríguez, 2012. Integrated networks. A territorial planning } \\
\text { proposal for long-term biodiversity conservation in urban, densely- } \\
\text { populated regions. The case of the Autonomous Region of Madrid, } \\
\text { Spain. Journal of Environmental Planning and Management, 55: 667-683 }\end{array}$ \\
\hline
\end{tabular}




\begin{tabular}{|c|c|}
\hline \multicolumn{2}{|l|}{ 6.5. Isolation } \\
\hline Category & Threats to conservation \\
\hline Type & Pressure \\
\hline Description & $\begin{array}{l}\text { This indicator assesses the degree of isolation of the protected area from } \\
\text { other natural or semi-natural areas }\end{array}$ \\
\hline Rationale & $\begin{array}{l}\text { Isolation of protected areas results from the increase in artifical areas in } \\
\text { their surroundings. It leads to additional pressures and threats on } \\
\text { protected areas which limit their conservation effectiveness (Spellerberg, } \\
\text { 1994; Pullin, 2002; Chape et al., 2008; Radeloff et al., 2010, Mora and } \\
\text { Sale, 2011). }\end{array}$ \\
\hline \multicolumn{2}{|r|}{ 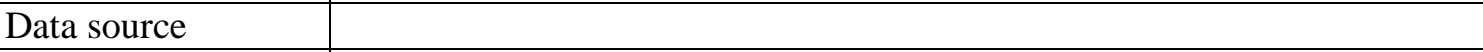 } \\
\hline \multicolumn{2}{|l|}{ Data availability } \\
\hline Updating & Every four years \\
\hline Scale & Ordinal scale, from 0 to 2 \\
\hline $\begin{array}{l}\text { Calculation and } \\
\text { interpretation }\end{array}$ & $\begin{array}{l}\text { The isolation of the protected area will be considered and valuated as } \\
\text { follows: } \\
\text { - Low: the natural or semi-natural areas in the } 500 \mathrm{~m} \text {-wide } \\
\text { perimeter from the protected area }(\mathrm{X}) \text { cover: } \mathrm{X} \geq 90 \% \rightarrow 0 \text { points } \\
\text { - Moderate: } 70 \leq \mathrm{X}<90 \% \rightarrow 1 \text { point } \\
\text { - High: } \mathrm{X}<70 \% \rightarrow 2 \text { points } \\
\text { Explanatory note } \\
\text { It is considered "natural areas": forests, riversides, forested meadows, } \\
\text { scrubland, rocky habitats, river courses and masses, and natural meadows } \\
\text { and pastures. } \\
\text { It is considered "semi-natural areas": urban or artificial green zones, golf } \\
\text { courses, agricultural land, meadows and pastures. } \\
\text { It is considered "artificial areas": urban, commercial, industrial, transport, } \\
\text { mining, and rubbish dumping zones. } \\
\text { For the development of this indicator, the dispersal abilities of the most } \\
\text { restricted taxa were considered: i.e. those taxa whose mobility is more } \\
\text { limited, such as invertebrates, fishes, amphibians and reptiles. Thus, they } \\
\text { require high physical connectivity among landscape units. }\end{array}$ \\
\hline Tendency & $\begin{array}{l}\text { The tendency will be positive if } \mathrm{X} \text { is higher than in the previous } \\
\text { assessment, stable if } \mathrm{X} \text { is the same in both assessments, and negative if } \mathrm{X} \\
\text { is lower than its previous value }\end{array}$ \\
\hline References & $\begin{array}{l}\text { Ley 42/2007, de } 13 \text { de diciembre, del Patrimonio Natural y de la } \\
\text { Biodiversidad. Arts. 17.g, } 19 . \mathrm{g}, 20 \text { y } 46 . \\
\text { - Spellerberg, I.F. 1994. Evaluation and Assessment for Conservation. } \\
\text { Chapman \& Hall, London. } \\
\text { Chape, S.; Spalding, M.; and Jenkins; M.D. 2008. The World's } \\
\text { Protected Areas: Status, Values and Prospects in the 21st Century. } \\
\text { Prepared by the UNEP World Conservation Monitoring Centre, } \\
\text { University of California Press, Berkeley, USA. } \\
\text { - Pullin, A. 2002. Conservation Biology. Cambridge University Press. } \\
\text { Cambridge, UK. } \\
\text { Mallarach, J.M.; Germain, J.; Sabaté, X.; y Basora, X. 2008. Protegits } \\
\text { de fet o de dret? Primera avaluació del sistema d'espais naturals } \\
\text { protegits de Catalunya. Institució Catalana d'Història Natural. } \\
\text { Disponible } \\
\text { http://ichn.iec.cat/Avaluaci\%C3\%B3\%20d\%27espais.htm } \\
\text { Radeloff, V.C., Stewart, S.I., Hawbaker, T.J., Gimmi, U., Pidgeon, }\end{array}$ \\
\hline
\end{tabular}




\begin{tabular}{|l|l|}
\hline & $\begin{array}{l}\text { A.M., Flather, C.H., Hammer, R.B., and Helmers, D.P., 2010. Housing } \\
\text { growth in and near United States protected areas limits their } \\
\text { conservation value. PNAS, 107: 940-945. }\end{array}$ \\
Mora, C. and Sale, P.F. 2011. Ongoing global biodiversity loss and the \\
need to move beyond protected areas: a review of the technical and \\
practical shortcomings of protected areas on land and sea. Marine \\
Ecology Progress Series, 434: 251-266. \\
- \\
Rodríguez-Rodríguez, 2012. Integrated networks. A territorial planning \\
proposal for long-term biodiversity conservation in urban, densely- \\
populated regions. The case of the Autonomous Region of Madrid, \\
Spain. Journal of Environmental Planning and Management, 55: 667- \\
683
\end{tabular}

\begin{tabular}{|c|c|}
\hline \multicolumn{2}{|l|}{ 6.6. Accessibility } \\
\hline Category & Threats to conservation \\
\hline Type & Pressure \\
\hline Description & $\begin{array}{l}\text { This indicators assesses the proximity of the protected area to high- } \\
\text { capacity transport infrastructures }\end{array}$ \\
\hline Rationale & $\begin{array}{l}\text { There exists a causal relationship between the proximity to transport } \\
\text { infrastructures and the degree of threat to a protected area (Pressey et al., } \\
\text { 2007; Chape et al., 2008; Nolte et al., 2010). }\end{array}$ \\
\hline \multicolumn{2}{|r|}{ (2, } \\
\hline \multicolumn{2}{|l|}{ Data availability } \\
\hline Updating & Every four years \\
\hline Scale & Ordinal scale, from 0 to 2 \\
\hline $\begin{array}{l}\text { Calculation and } \\
\text { interpretation }\end{array}$ & $\begin{array}{l}\text { The accessibility to the protected area will be considered and valuated as } \\
\text { follows: } \\
\text { - Low: there is a high-capacity transport infrastructure* at } 10 \mathrm{~km} \\
\text { or further from the perimeter of the protected area } \rightarrow 0 \text { points } \\
\text { - Moderate: there is a high-capacity transport infrastructure at less } \\
\text { than } 10 \mathrm{~km} \text { from the perimeter of the protected area } \rightarrow 1 \text { point } \\
\text { - High: the protected area is crossed by at least one high-capacity } \\
\text { transport infrastructure } \rightarrow 2 \text { points } \\
\text { Explanatory note } \\
\text { *High-capacity transport infrastructure includes highways and other } \\
\text { roads of, at least, two lanes per direction. }\end{array}$ \\
\hline Tendency & $\begin{array}{l}\text { The tendency will be positive if the value of the indicator is higher than in } \\
\text { the previous assessment, stable, if it is the same in both assessments, and } \\
\text { negative if the most recent value of the indicator is lower than the } \\
\text { previous one }\end{array}$ \\
\hline References & $\begin{array}{l}\text { - Pressey, R.L.; Cabeza, M.; Watts, M.E.; Cowling, R.M.; and Wilson, } \\
\text { K.A. 2007. Conservation planning in a changing world. Trends in } \\
\text { Ecology and Evolution } 22 \text { (11): 583-592. } \\
\text { Chape, S.; Spalding, M.; and Jenkins; M.D. 2008. The World's } \\
\text { Protected Areas: Status, Values and Prospects in the 21st Century. } \\
\text { Prepared by the UNEP World Conservation Monitoring Centre, } \\
\text { University of California Press, Berkeley, USA. } \\
\text { Mallarach, J.M.; Germain, J.; Sabaté, X.; y Basora, X. 2008. Protegits } \\
\text { de fet o de dret? Primera avaluació del sistema d'espais naturals } \\
\text { protegits de Catalunya. Institució Catalana d'Història Natural. } \\
\text { Disponible } \\
\text { http://ichn.iec.cat/Avaluaci\%C3\%B3\%20d\%27espais.htm }\end{array}$ \\
\hline
\end{tabular}




\begin{tabular}{|l|l|}
\hline & Nolte, C.; Leverington, F.; Kettner, A.; Marr, M.; Nielsen, G.; \\
& Bomhard, B.; Stolton, S.; Stoll-Kleemann, S.; and Hockings, M. 2010. \\
& Protected Area Management Effectiveness Assessments in Europe. A \\
& review of application, methods and results. University of Greifswald. \\
& Greifswald, Germany. \\
\hline
\end{tabular}

\begin{tabular}{|c|c|}
\hline Category & Threats to conservation \\
\hline Type & Pressure \\
\hline Description & $\begin{array}{l}\text { This indicator assesses the temporal variation in the number of visitors to } \\
\text { the protected area }\end{array}$ \\
\hline Rationale & $\begin{array}{l}\text { High numbers of visitors amplify the number of impacts that visitors can } \\
\text { have on protected areas and their resources (Chape et al., 2008). The } \\
\text { most relevant among these impacts are: noise and disturbance to fauna; } \\
\text { trampling, mutilation and uprooting of plants; colapse and degradation of } \\
\text { public use infrastructures; littering; habitat destruction as a result of new } \\
\text { visitors infrastructures; or higher risk of forest fires (Chape } \text { et al., 2008) }\end{array}$ \\
\hline \multicolumn{2}{|l|}{ Data source } \\
\hline \multicolumn{2}{|l|}{ Data availability } \\
\hline Updating & Annually \\
\hline Scale & Ordinal scale, from 0 to 2 \\
\hline $\begin{array}{l}\text { Calculation and } \\
\text { interpretation }\end{array}$ & 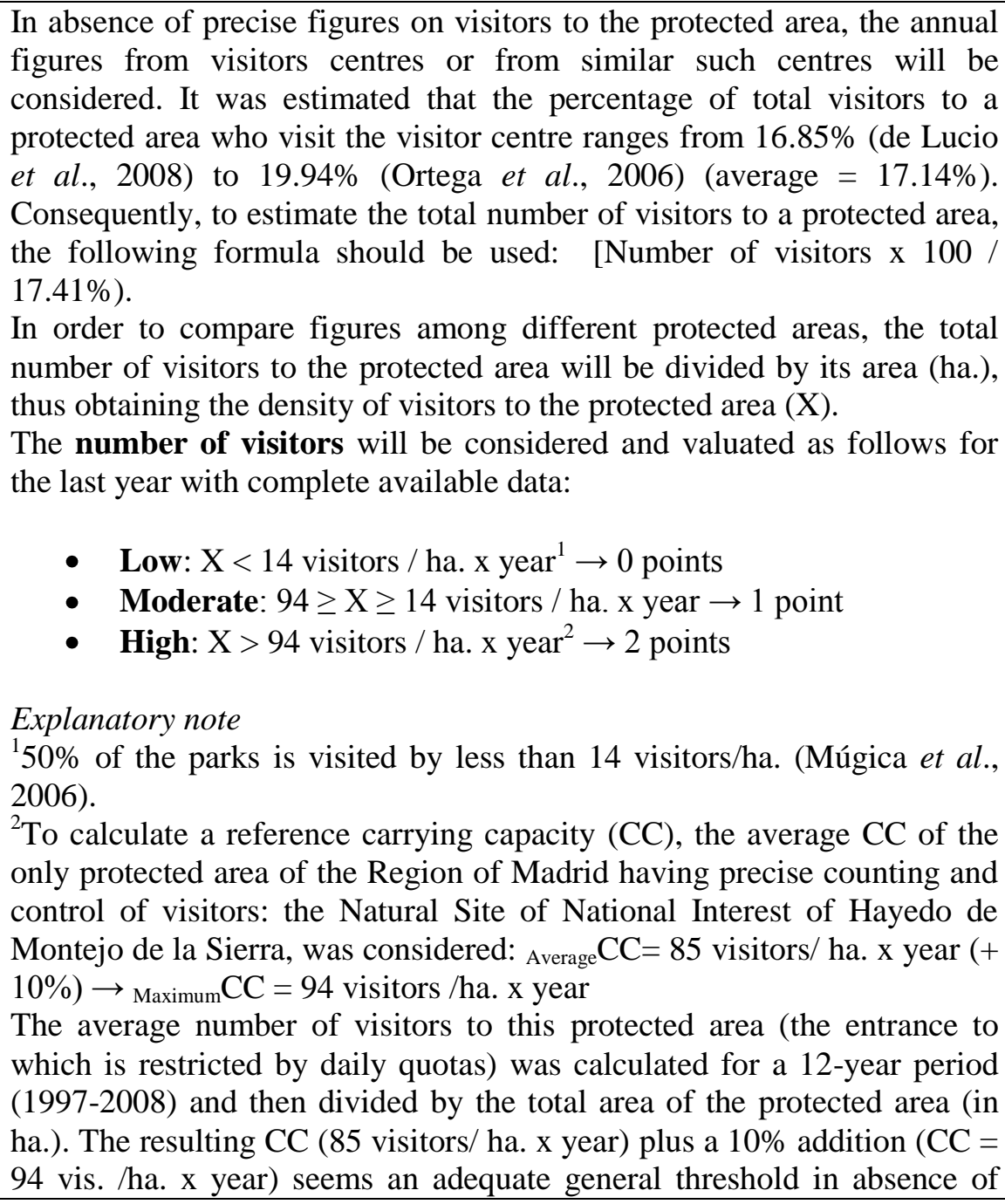 \\
\hline
\end{tabular}




\begin{tabular}{|c|c|}
\hline & $\begin{array}{l}\text { other references, taking into account the fragility of the ecosystem present } \\
\text { (beech forest in the limit of its distribution range) and the small size of } \\
\text { this protected area ( } 250 \text { ha.). }\end{array}$ \\
\hline Tendency & $\begin{array}{l}\text { The tendency will be considered positive if the average number of visitors } \\
\text { to the protected area in the last two years analysed is smaller than the } \\
\text { previous five-year average number. The tendency will be considered as } \\
\text { stable if both average numbers are equal, and it will be considered as } \\
\text { negative if the previous five-year average number of visitors is higher } \\
\text { than the average number for the last two years assessed }\end{array}$ \\
\hline References & $\begin{array}{l}\text { - Múgica, M.; Gómez-Limón, J.; de Lucio, J.V.; y Puertas, J. } 2006 . \\
\text { Anuario EUROPARC-España del estado de los espacios naturales } \\
\text { protegidos 2005. Fundación Fernando González Bernáldez. Madrid. } \\
\text { - Ortega, J.; Gómez-Limón, J.; Rovira, P.; López-Claramunt, A.; y } \\
\text { Gabaldón, J.E. 2006. Evaluación del papel que cumplen los } \\
\text { equipamientos de uso publico en los espacios naturales protegidos. } \\
\text { Fundación Fernando González Bernáldez. Madrid. } \\
\text { De Lucio, J.V.; Múgica, M.; Gómez-Limón, J.; Martínez-Alandi, C.; } \\
\text { Puertas, J.; y Atauri, J.A. 2008. Anuario EUROPARC-España del estado } \\
\text { de los espacios naturales protegidos 2007. Fundación Fernando } \\
\text { González Bernáldez. Madrid. } \\
\text { Chape, S.; Spalding, M.; and Jenkins; M.D. 2008. The World's } \\
\text { Protected Areas: Status, Values and Prospects in the 21st Century. } \\
\text { Prepared by the UNEP World Conservation Monitoring Centre, } \\
\text { University of California Press, Berkeley, USA. Mallarach, J.M.; } \\
\text { Germain, J.; Sabaté, X.; y Basora, X. 2008. Protegits de fet o de dret? } \\
\text { Primera avaluació del sistema d'espais naturals protegits de Catalunya. } \\
\text { Institució Catalana d'Història Natural. Disponible en: } \\
\text { http://ichn.iec.cat/Avaluaci\%C3\%B3\%20d\%27espais.htmRodríguez- } \\
\text { Rodríguez, D. 2009. Mitigación de los impactos del turismo en espacios } \\
\text { naturales protegidos y mejora de su financiación a través de medidas } \\
\text { económicas. El caso de la Comunidad de Madrid. Boletín de la AGE, 50: } \\
\text { 217-238. } \\
\text { Rodríguez-Rodríguez, 2012. Integrated networks. A territorial planning } \\
\text { proposal for long-term biodiversity conservation in urban, densely- } \\
\text { populated regions. The case of the Autonomous Region of Madrid, } \\
\text { Spain. Journal of Environmental Planning and Management, 55: 667-683 }\end{array}$ \\
\hline
\end{tabular}

\begin{tabular}{|l|l|}
\hline 6.8. Activities performed by visitors \\
\hline Category & Threats to conservation \\
\hline Type & Pressure \\
\hline Description & $\begin{array}{l}\text { This indicator assesses the main types of activities performed by visitors } \\
\text { to protected areas to valuate the degree of threat these activities pose on } \\
\text { the protected area or its resources }\end{array}$ \\
\hline Rationale & $\begin{array}{l}\text { Recreational activities are the most frequent and serious threat to the } \\
\text { protected areas in industrialised countries (Rodríguez-Rodríguez, 2008; } \\
\text { Leverington } \text { et al., 2010; Nolte et al., 2010). The more recreational } \\
\text { activities are performed, the higher the number of incidents inside } \\
\text { protected areas occur (Chape } \text { et al., 2008) }\end{array}$ \\
\hline Data source & \multicolumn{1}{|l|}{ Every two years } \\
\hline Data availability & Ordinal scale, from 0 to 2 \\
\hline Updating & $\begin{array}{l}\text { The three main activities performed by visitors to the protected area will } \\
\text { be considered. }\end{array}$ \\
\hline Scale &
\end{tabular}




\begin{tabular}{|c|c|}
\hline & 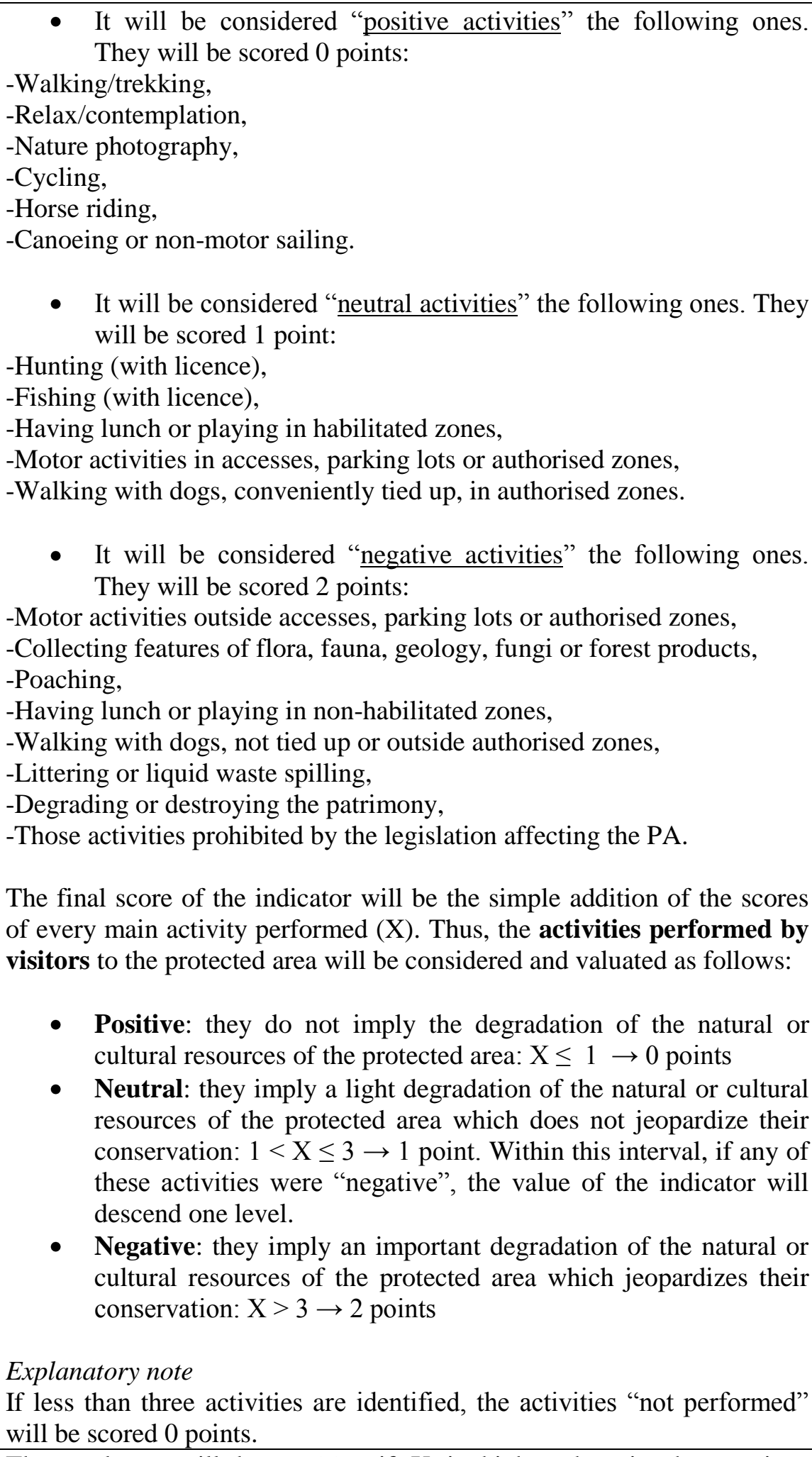 \\
\hline Tendency & $\begin{array}{l}\text { The tendency will be positive if } \mathrm{X} \text { is higher than in the previous } \\
\text { assessment, stable if } \mathrm{X} \text { is the same in both assessments, and negative if } \mathrm{X} \\
\text { is lower than its previous value }\end{array}$ \\
\hline References & $\begin{array}{l}\text { - Barrado, D. 1999. Actividades de ocio y recreativas en el medio natural } \\
\text { de la Comunidad de Madrid. La ciudad a la búsqueda de la naturaleza. } \\
\text { Consejería de Medio Ambiente. Comunidad de Madrid. Madrid. } \\
\text { VVAA. Cuadernos del Arboreto Luis Ceballos. } N^{o} \text { 2. Consejería de } \\
\text { Medio Ambiente, Vivienda y Ordenación del Territorio. Comunidad de } \\
\text { Madrid. }\end{array}$ \\
\hline
\end{tabular}




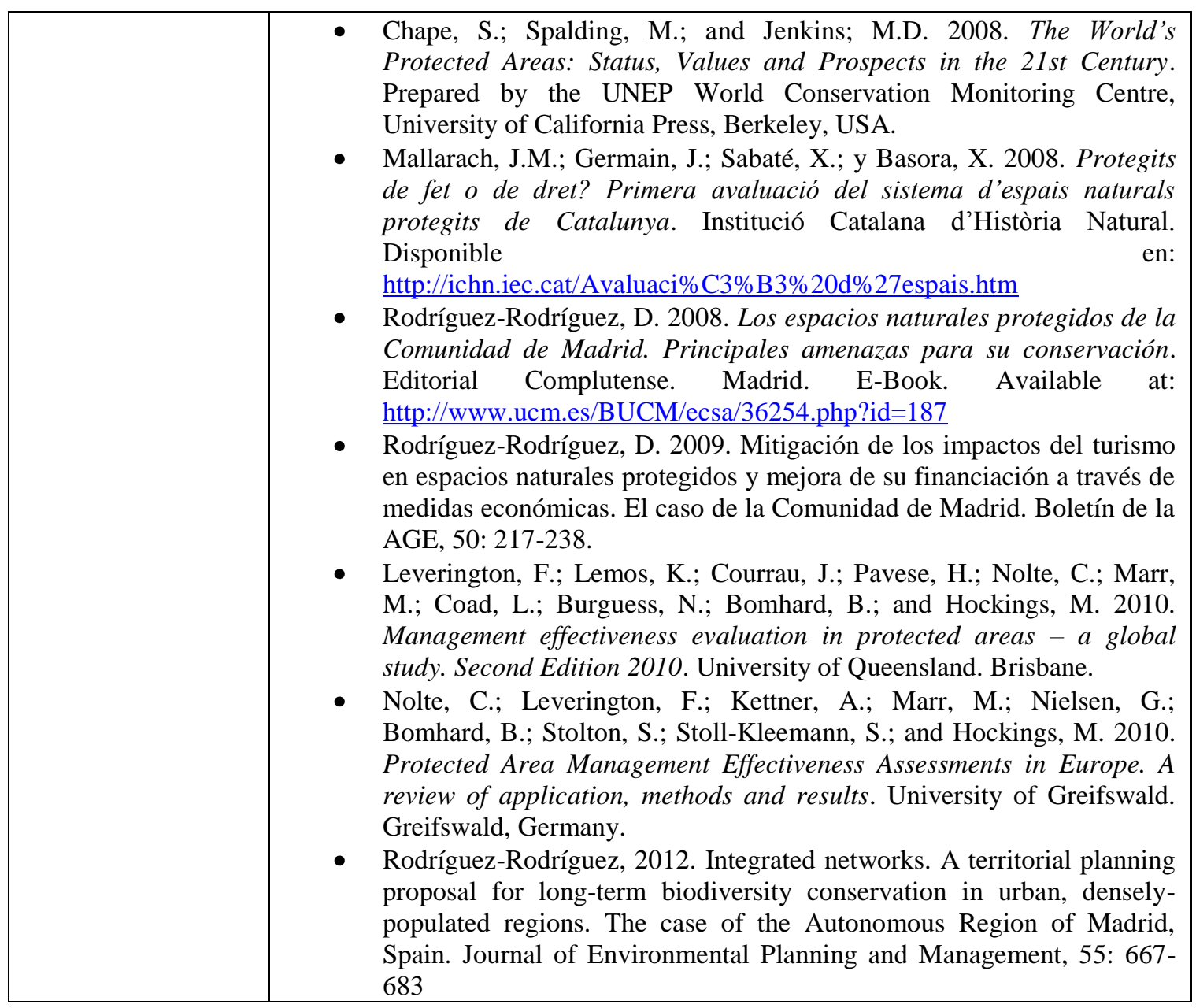

\begin{tabular}{|c|c|}
\hline \multicolumn{2}{|c|}{ 6.9. Local population density } \\
\hline Category & Threats to conservation \\
\hline Type & Pressure \\
\hline Description & $\begin{array}{l}\text { This indicator assesses the population density in the municipalities } \\
\text { included in the protected area }\end{array}$ \\
\hline Rationale & $\begin{array}{l}\text { The higher the population density inside a protected area or in its } \\
\text { surroundings is, the bigger and more numerous pressures on the protected } \\
\text { area or on its resources will be (Spellerberg, 1994; Pullin, 2002; Mora } \\
\text { and Sale, 2011). A high population density can also imply a higher } \\
\text { frequency of incidents (Chape et al., 2008; Mora and Sale, 2011), and } \\
\text { more difficulty in the implementation of law (Mora and Sale, 2011). As a } \\
\text { result, it is an useful indicator on the interactions of the human beings } \\
\text { with their environment (Ellis and Ramankutti, 2008) }\end{array}$ \\
\hline \multicolumn{2}{|r|}{ ( } \\
\hline \multicolumn{2}{|l|}{ Data availability } \\
\hline Updating & Every two years \\
\hline Scale & Ordinal scale, from 0 to 2 \\
\hline $\begin{array}{l}\text { Calculation and } \\
\text { interpretation }\end{array}$ & $\begin{array}{l}\text { The population residing in each of the municipalities included in the PA } \\
\text { will be divided by the area of each municipality }\left(\mathrm{km}^{2}\right) \text { thus obtaining the } \\
\text { population density in that municipality. If there is more than one } \\
\text { municipality included in the PA, the population densities for all the } \\
\text { included municipalities will be calculated, each weighted by the }\end{array}$ \\
\hline
\end{tabular}




\begin{tabular}{|c|c|}
\hline & 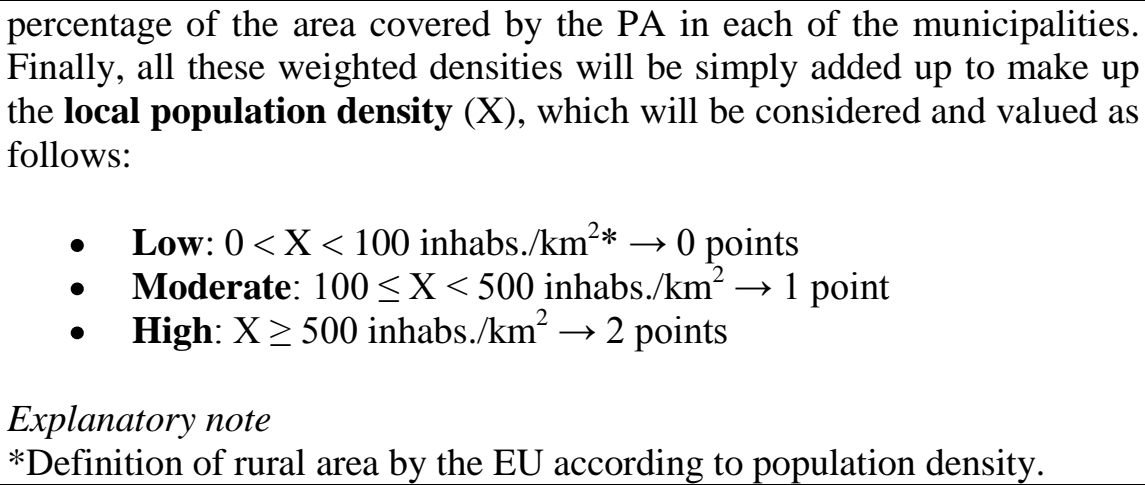 \\
\hline Tendency & $\begin{array}{l}\text { The tendency will be positive if } \mathrm{X} \text { is higher than in the previous } \\
\text { assessment, stable, if } \mathrm{X} \text { is the same in both assessments, and negative if } \\
\mathrm{X} \text { is lower than its previous value }\end{array}$ \\
\hline References & $\begin{array}{l}\text { - Spellerberg, I.F. 1994. Evaluation and Assessment for Conservation. } \\
\text { Chapman \& Hall, London. } \\
\text { Pullin, A. 2002. Conservation Biology. Cambridge University Press. } \\
\text { Cambridge, UK. } \\
\text { - Chape, S.; Spalding, M.; and Jenkins; M.D. 2008. The World's } \\
\text { Protected Areas: Status, Values and Prospects in the 21st Century. } \\
\text { Prepared by the UNEP World Conservation Monitoring Centre, } \\
\text { University of California Press, Berkeley, USA. } \\
\text { - Ellis, E. C. and Ramankutty, N. 2008. Putting people in the map: } \\
\text { anthropogenic biomes of the world. Frontiers in Ecology and the } \\
\text { Environment } 6 \text { (8): 439-447. } \\
\text { Mallarach, J.M.; Germain, J.; Sabaté, X.; y Basora, X. 2008. Protegits } \\
\text { de fet o de dret? Primera avaluació del sistema d'espais naturals } \\
\text { protegits de Catalunya. Institució Catalana d'Història Natural. } \\
\text { Disponible } \\
\text { http://ichn.iec.cat/Avaluaci\%C3\%B3\%20d\%27espais.htm } \\
\text { Mora, C. and Sale, P.F. 2011. Ongoing global biodiversity loss and the } \\
\text { need to move beyond protected areas: a review of the technical and } \\
\text { practical shortcomings of protected areas on land and sea. Marine } \\
\text { Ecology Progress Series, 434: 251-266. }\end{array}$ \\
\hline
\end{tabular}

